http://dx.doi.org/10.22201/igl.14053322p.BSGM560105

Boletín de la Sociedad Geológica Mexicana

Tomo LVI, NúM. 1, 2003 P. 56-86

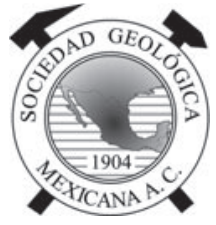

\title{
El origen de la vida desde un punto de vista geológico
}

\author{
J. Arturo Gómez-Caballero* y Jerjes Pantoja-Alor
}

Instituto de Geología, Universidad Nacional Autónoma de México

Apdo. Postal 70-296, 04510 México, D. F., México.

* gomezcab@servidor.unam.mx

\section{Resumen}

El origen de la vida ha sido considerado como el problema científico más importante desde los albores de la ciencia. Para tratar de resolverlo se han elaborado diversas hipótesis que tuvieron inicio con la generación espontánea, sostenida por Aristóteles, que tuviera vigencia hasta 1864, cuando fue desacreditada por los experimentos de Pasteur.

A partir de entonces surgieron las ideas acerca del origen químico de la vida, que diferían entre sí en el entorno geográfico considerado. Los primeros registros de tales ideas corresponden a Ernst Haeckel, en 1866, y a T.H. Huxley, en 1868; sin embargo, éstos han sido superados en popularidad por Darwin, quien enunciara la hipótesis, en 1871, de que la vida se hubiese originado en "una pequeña charca tibia". Más tarde, Oparin y Haldane, independientemente uno del otro, propusieron que la vida tuvo su inicio en el mar, en la zona cercana a su superficie o en sus orillas, a partir de un "caldo primordial", hipótesis que alcanzó una gran notoriedad a raíz del clásico experimento de Urey y Miller, en el que se efectuó la síntesis de aminoácidos, publicado en 1953.

La hipótesis de la panspermia ("semillas en todas partes"), que proclama el origen extraterrestre de la vida, fue enunciada por Arrhenius en 1903. Esta corriente se ha visto reforzada recientemente por el descubrimiento tanto de supuestas formas de vida en meteoritos marcianos, como de la existencia de sustancias "orgánicas" complejas en el espacio sideral. La presencia de materia orgánica extraterrestre no es de sorprender, puesto que los elementos esenciales para la vida $(\mathrm{C}, \mathrm{H}, \mathrm{O}$, N) se formaron desde las primeras etapas de la evolución del universo.

En la actualidad, es la hipótesis hidrotermal la que debe considerarse como más factible debido a que la profundidad de los mares proporcionaba protección contra las condiciones adversas imperantes en la superficie en esa época, y a que la complejidad de los sistemas hidrotermales proporciona una gran variedad de condiciones que se consideran necesarias para que se haya originado la vida: permiten una gama más amplia de acidez-alcalinidad $(\mathrm{pH})$ y de condiciones reductoras (Eh) que las aguas de los mares; presentan minerales con un extraordinario comportamiento químico, como el grupo de las zeolitas o las arcillas del grupo de la esmectita (montmorillonita); y están sujetos energía geotérmica, con lo cual se evita la influencia nociva de la radiación ultravioleta asociada a la energía solar; y presentan, como posible fuente alterna de energía, una gran diversidad de reacciones químicas exotérmicas, lo que pudiera ser aprovechado para el proceso de metabolismo.

La hipótesis hidrotermal, por otra parte, no es ajena a la panspermia. Independientemente de que la vida se haya originado en la Tierra o fuera de ella, el descubrimiento reciente de agua, originalmente en estado líquido, lo que se considera como condición determinante para el origen de la vida, en meteoritos primitivos de la parte exterior del cinturón de asteroides, que fue calentada por la desintegración radiactiva de isótopos de corta vida media en los inicios del sistema solar, hace que la hipótesis hidrotermal trascienda los límites terrestres y se extienda hacia, por lo menos, una parte del sistema solar.

Palabras clave: Origen de la vida, hipótesis hidrotermal, panspermia. 


\begin{abstract}
The origin of life is generally regarded as the most crucial problem since the dawn of scientific thought. For its solution, several hypotheses have been proposed, beginning with that of the spontaneous generation supported by Aristotle, which had validity until 1864, when Pasteur experimentally demonstrated that it was wrong.

Since then, a number of ideas concerning the origin of life by chemical reactions arose, which differed from each other in its particular geographical environment. The first ones were proposed in 1866 by Ernst Haeckel, and in 1868 by T.H. Huxley, but nowadays they have been surpassed in popularity by the Darwin's hypothesis of the origin of life "in some warm little pond", enounced in 1871. Later, independently from each other, Oparin and Haldane proposed the hypothesis of the origin of life from a "primordial soup" that had a great acceptance, especially afterwards the classical experiment of Urey-Miller on amino acid synthesis, published in 1953.

The panspermia hypothesis ("seeds everywhere"), which proposes an extraterrestrial origin of life, was enunciated by Arrhenius in 1903. This assumption has been recently strengthened by the discovery of alleged bacteria fossils in Martian meteorites, as well as by the presence in the outer space of complex organic compounds.

Nowadays, the hydrothermal hypothesis should be considered as the most feasible of them, because the depth of the seawaters served as a shelter against the hostile conditions in the surface in that time. Besides, the inherent complexity of the hydrothermal systems offered a wide range of parameters that favor the origin of life: more suitable acidity-alkalinity $(\mathrm{pH})$ and reducing conditions $(\mathrm{Eh})$ than the seawaters; presence of minerals with extraordinary chemical properties, such as the zeolite group or the smectite (montmorillonite) clay group; dependence on the geothermal energy, avoiding the deleterious effect of the ultraviolet radiation of the solar energy; and availability of diverse chemical compounds that react exothermically, which can be used for the metabolism process.

The hydrothermal hypothesis does not exclude the panspermia. Whether life has been originated in the Earth or outside it, the recent discovery of water, originally in liquid state, regarded as a necessary condition for life, in primitive meteorites from the outer part of the asteroid belt, which was heated by radioactive decay of short-lived isotopes, abundant in the beginnings of the solar system, make the hydrothermal hypothesis transpose the Earth limits toward, at least partially, the solar system.
\end{abstract}

Keywords: Origin of life, hydrothermal hypothesis, panspermia.

\section{Introducción}

En el estudio presente se pretende ofrecer una descripción somera del papel del hidrotermalismo en el origen y desarrollo de la vida. El origen de la vida ha sido objeto de especulación filosófica y científica desde los albores de la civilización. Las teorías idealistas tenían fundamento en la tradición, oral o escrita, de las religiones. Conviene aquí hacer notar que, dentro de la nomenclatura científica, hipótesis es una respuesta a cierta interrogante, que cae dentro de lo posible con base en la observación y experimentación, pero con un grado de certidumbre inferior al de una teoría. En este artículo, se hace una relación sucinta de las hipótesis científicas sobre el origen de la vida, cuya validez depende del entorno geográfico, haciendo énfasis en la más reciente de ellas, la hipótesis hidrotermal.

Dado que la materia orgánica que forma los cuerpos vivos está formada esencialmente por los elementos químicos $\mathrm{C}, \mathrm{H}, \mathrm{O}$ y $\mathrm{N}$, se juzgó conveniente exponer a continuación una reseña de la formación de estos elementos por reacciones en las estrellas, coincidiendo en esto con la organización del clásico libro El origen de la vida, de Oparin.

\section{Origen en el universo de los elementos esenciales para la vida: $\mathrm{C}, \mathrm{H}, \mathrm{O}, \mathrm{N}$}

Al considerar el origen de la Tierra, para entender el origen de los elementos, se tiene que partir desde los inicios del universo que, según la teoría de mayor aceptación en la actualidad, la del Big Bang (desarrollada por George Gamow con base en el descubrimiento, hecho por Edwin Hubble, de que el universo está en expansión), tuvo lugar hace $14 \mathrm{Ga}$ (giga-años; $1 \mathrm{Ga}=1 \times 10^{9}$ años), edad estimada por el corrimiento hacia el rojo de las galaxias distantes. No debe sorprender la presencia de agua en la Tierra ni en el resto de los cuerpos del universo, pues los elementos que la componen, hidrógeno y oxígeno, se forman en una etapa temprana de la evolución de los cuerpos estelares. El hidrógeno puede considerarse como la materia prima de la que se derivan todos los demás elementos; es el combustible que genera energía por fusión produciendo helio. Al empezar a disminuir la cantidad de hidrógeno, la temperatura de la estrella disminuye y la capa exterior de ésta se expande: es el inicio de la etapa de gigante roja. El helio se empieza a acumular en el núcleo de la estrella hasta producir el colapso de éste por gravitación, lo que eleva la 
temperatura lo suficiente para que se inicie la fusión de helio, que produce carbono. A su vez, el carbono da lugar al nitrógeno y al oxígeno. Estos procesos se expresan por las reacciones sucesivas siguientes:

$$
\begin{aligned}
{ }^{1} \mathrm{H}+\mathrm{p} & \rightarrow{ }^{2} \mathrm{D}+\beta^{+} \\
{ }^{2} \mathrm{D}+\mathrm{p} & \rightarrow{ }^{3} \mathrm{He}+\gamma \\
2{ }^{3} \mathrm{He} & \rightarrow{ }^{4} \mathrm{He}+2 \mathrm{p} \\
3{ }^{4} \mathrm{He} & \rightarrow{ }^{12} \mathrm{C}+\gamma \\
{ }^{12} \mathrm{C}+\mathrm{p} & \rightarrow{ }^{13} \mathrm{~N}+\gamma \\
{ }^{12} \mathrm{C}+{ }^{4} \mathrm{He} & \rightarrow{ }^{16} \mathrm{O}
\end{aligned}
$$

Conforme la temperatura se eleva aún más, el ${ }^{12} \mathrm{C}$ y el ${ }^{16} \mathrm{O}$, que además producen elementos de número atómico cercano a ellos mediante la captura o emisión de partículas subatómicas, se fusionan de manera explosiva para producir ${ }^{28} \mathrm{Si}$ y otros elementos de número atómico cercano a éste, dando lugar a la etapa de desintegración estelar, la de supernova:

$$
{ }^{12} \mathrm{C}+{ }^{16} \mathrm{O} \rightarrow{ }^{28} \mathrm{Si}
$$

En estrellas de densidad muy alta, la fusión del ${ }^{12} \mathrm{C}$ y el ${ }^{16} \mathrm{O}$ se efectúa hasta casi agotar ambos elementos, sin la destrucción de las mismas. Con el incremento resultante de la temperatura, sobreviene la fusión de los átomos de ${ }^{28} \mathrm{Si}$ entre sí, que es de tal violencia que produce el estallido que marca el fin de un ciclo estelar, originándose la supernova. El producto de esta fusión es el ${ }^{56} \mathrm{Ni}$, inestable, que por captura de dos partículas beta se transforma en ${ }^{56} \mathrm{Fe}$, estable:

$$
\begin{aligned}
2{ }^{28} \mathrm{Si} & \rightarrow{ }^{56} \mathrm{Ni} \\
{ }^{56} \mathrm{Ni}+2 \beta^{-} & \rightarrow{ }^{56} \mathrm{Fe}
\end{aligned}
$$

Por su parte, el Fe forma los elementos más pesados que él aceptando partículas alfa, protones y neutrones y aceptando o emitiendo partículas beta; no obstante, ya no es capaz de producir reacciones de fusión, porque está situado en la cima de la curva de energía de enlace nuclear. Esto es debido a que las reacciones de fusión entre elementos situados en la curva a la derecha de este punto absorberían energía en vez de liberarla.

Según lo anterior, el carbono, la base para la vida, es elaborado en el núcleo de las gigantes rojas, en particular en el de las estrellas AGB (Asymptotic Giant Branch), que son gigantes rojas de edad intermedia, por el denominado "proceso triple alfa" (la fusión de tres núcleos de helio, que son llamados partículas alfa). La formación estelar del carbono fue propuesta por Fred Hoyle en la década de 1950 y recibió el nombre de "principio antrópico"; sin embargo, los compuestos "orgánicos" (nombre erróneo debido a la antigua teoría del "vitalismo", que sostenía que tales compuestos únicamente podían ser producidos por una "fuerza vital" propia de la materia viva) identificados en ellas son relativamente sencillos; sólo son de cadena abierta, como el acetileno.
La materia orgánica con cierta complejidad se caracteriza por contener anillos de seis y de cinco átomos de carbono. Estos compuestos de cadena cerrada, o cíclicos, también llamados "aromáticos" por su olor característico, que tienen como base al benceno, han sido identificados, por medio de su espectro infrarrojo, solamente en estrellas que se encuentran en una fase estelar más avanzada que las gigantes rojas: la etapa de transición a la de "nebulosa planetaria" (Cernicharo et al., 2001). Las nebulosas planetarias reciben este nombre porque consisten en estrellas que están en la fase de "enanas blancas", rodeadas por una brillante nube de gas y polvo estelar, que en los telescopios dan la apariencia de sistemas formados por un sol y sus planetas.

La etapa de gigante roja de una estrella consiste en que mientras en el núcleo de la misma se efectúan reacciones de fusión de helio formándose carbono como producto, en su superficie cesó temporalmente la fusión de hidrógeno en helio dando lugar a la formación de una envoltura de gases y polvo, en los cuales está presente el carbono proveniente del núcleo, llevado probablemente por corrientes de convección, la que se expande hasta ocupar un volumen unas 70 veces mayor. En la etapa de transición, la contracción gravitacional en el núcleo de la estrella hace que aumente considerablemente la temperatura con emisión de radiaciones, lo que origina una inestabilidad que hace que la estrella pulse y que el material que forma la envoltura sea expulsado a gran velocidad. Para ilustrar esta fase, se puede poner como ejemplo el del sol, el cual, debido a que no posee una gran masa, al final de su ciclo estelar expelerá la mayor parte de la materia que forma su envoltura, la que llegará hasta la órbita de Marte, en lo que se denomina “etapa de gigante roja". Subsecuentemente, esta materia será impulsada a una gran velocidad y se expandirá hasta alcanzar la órbita de Plutón en unos 10,000 años, entrando en la etapa de "nebulosa planetaria". Después de este tiempo, la materia, que seguirá en expansión, se hará de densidad tan baja que ya no será detectada, quedando sólo una enana blanca. El telescopio espacial Hubble ha fotografiado la etapa de transición en un caso en el que la emisión de masa es bipolar, es decir a lo largo de un eje hacia uno y otro extremo del mismo, dando origen a una especie de mancuerna con la enana blanca en el centro.

El material expulsado por la gigante roja consiste en hidrocarburos de cadena abierta, como el acetileno, formados hasta por ocho átomos de carbono. La importante etapa de transición es en la que los fotones de la radiación ultravioleta, así como el "viento estelar", de gran velocidad, procedentes de las enanas blancas, actúan sobre tales moléculas simples, que fueron formadas por radiación de longitud de onda larga, rompiendo sus enlaces y promoviendo nuevas reacciones que dan lugar a la formación del benceno mediante un proceso que ha sido llamado "polimerización del acetileno". En la fase siguiente, la de nebulosa planetaria, no se detecta benceno, sino sólo líneas espectrales no identificadas que corresponden a 
compuestos muy complejos que se cree sean aromáticos (PAHs, polycyclic aromatic hydrocarbons), con cadenas formadas por cientos de átomos de carbono (Cernicharo et al., 2001).

Con base en lo anterior, puede concluirse que, por lo menos en parte, el material carbonoso de nuestro sistema solar podría haberse originado en las fases de nebulosa planetaria, de etapa de transición o de gigante roja de una estrella o, incluso, estar formada por todas estas fases en conjunto procedentes de una gran diversidad de estrellas. La otra parte, podría deberse a que, ya en la fase de nebulosa previa al origen del sistema solar (protonebulosa), hayan tenido lugar los procesos de polimerización debido al efecto de la explosión de la supernova que también activó el colapso gravitacional de la protonebulosa.

\section{Origen del sistema solar y de la Tierra}

La teoría sobre la formación del sistema solar y de la Tierra de mayor aceptación en la actualidad se puede resumir en las siguientes etapas:

1. Existencia de una nebulosa de gas y polvo (partículas de material rocoso de tamaño microscópico, cubiertas por hielo formado principalmente por $\mathrm{CO}_{2}, \mathrm{CH}_{4}$ y $\mathrm{NH}_{3}$ ). Se formó por aglomeración de la fase gaseosa emitida por la explosión de una supernova y posiblemente con aporte de otro tipo de estrellas, como las gigantes rojas, como ya se dijo.

2. Esta nebulosa se activó hace aproximadamente 4.6 $\mathrm{Ga}$, debido a la energía proporcionada por las ondas de choque de una supernova vecina, que originó la aglomeración de la materia difusa produciendo una protonebulosa. Este evento causó que, por atracción gravitacional, el gas y el polvo de la protonebulosa se concentraran en un globo dotado de rotación producida por el citado colapso gravitacional, como ha sido verificado en todos los casos que han podido ser observados en el universo. Conforme progresa la contracción, la velocidad de rotación aumenta debido al principio de conservación del momento angular. La fuerza centrífuga asociada a la rotación tiende a dispersar el material del sistema protosolar recién formado, pero esta fuerza es canalizada hacia la formación alrededor del ecuador del protosol, perpendicularmente al eje de rotación, de un disco del que se separan los anillos que darán origen a los planetas. Aunque la masa del sol equivale al $99.85 \%$ del total del sistema, el momento angular de los protoplanetas, principalmente Júpiter, representa el $95 \%$ del total (Turekian, 1972), lo que evita la destrucción de la protoestrella. En la hipótesis de la nebulosa, expuesta originalmente por el filósofo alemán Immanuel Kant y perfeccionada subsecuentemente, en 1796, por el astrónomo y matemático francés, Pierre Laplace, todo el disco se calentaría a gran temperatura. En la actualidad se considera que la materia del disco, inicialmente fría, empezó a calentarse gradualmente conforme la contracción gravitacional en el globo central aumentaba, hasta alcanzar, por lo menos en la parte interna del disco, en la que queda ubicada la Tierra, una temperatura lo suficientemente alta como para hacer que la fase sólida pasara al estado gaseoso, exceptuando el material rocoso más refractario. Por su parte, la parte externa del disco quedó relativamente fría. Sin embargo, la radiación de la supernova que activó a la nebulosa debió haber sido lo suficientemente intensa como para destruir todo rastro de desintegración radiactiva útil para fechar, ya que hasta la fecha no se ha obtenido datación alguna en los meteoritos que sea superior a los $4.6 \mathrm{Ga}$. Se infiere el carácter presolar de estas partículas, llamadas granos presolares, con base en relaciones isotópicas diferentes a las del sistema solar, dadas por la abundancia en ellas de ${ }^{28} \mathrm{Si},{ }^{44} \mathrm{Ti},{ }^{18} \mathrm{O}$ y ${ }^{26} \mathrm{Al}$, entre otros. Subsecuentemente, por condensación de esta fase gaseosa sobrevino la formación, en tres etapas, de los siguientes minerales, según el excelente resumen que de la ciencia de los meteoritos hacen Sánchez-Rubio et al. (2001): primera etapa, en la que se forman los llamados CAIs (calciumaluminum inclusions): corindón, perovskita, melilita, espinela, Fe-Ni y diópsido; en una segunda etapa se forman los cóndrulos: olivino, piroxeno y plagioclasa; y en una tercera etapa se forma la matriz de las condritas: olivino alto en Fe, piroxeno, magnetita, troilita, etc. Por el contrario, en la parte ocupada por los asteroides, principalmente en su faja externa, se conservaron en estado sólido algunas partículas de material refractario de la nebulosa. Los meteoritos se producen por fragmentación, debida a colisión, de su asteroide parental y son sacados de su órbita por el fuerte empuje gravitacional de Júpiter. El desarrollo de la geoquímica isotópica ha permitido identificar meteoritos que provienen de Marte, del que fueron desprendidos por fuertes impactos meteoríticos y permanecieron en el espacio durante varios millones de años antes de ser atraídos por el campo gravitacional terrestre.

Los meteoritos provenientes de la región externa del cinturón de asteroides son denominados "meteoritos primitivos"; es decir, que fueron los primeros en formarse. Uno de los meteoritos de tal tipo, que ha sido de gran importancia para el estudio de los orígenes del sistema solar, es el Allende (Figura 1), caído a pocos kilómetros al SW de Jiménez, Chihuahua; en él, fueron reconocidos dos tipos de CAIs: el primero formado por cóndrulos gruesos, constituidos por gehlenita y fassaíta titanífera con espinela y anortita en cantidad escasa; el segundo tipo consiste en fragmentos irregulares de color blanco o rosado formados por melilita, fassaíta y espinela, con nefelina, sodalita y anortita como minerales secundarios y perovskita e hibonita como accesorios. La edad del meteorito Allende, obtenida en CAIs por el método $\mathrm{Pb}-\mathrm{Pb}$, es de $4.566 \pm 0.002 \mathrm{Ga}$ (Chen y Wasserburg, 1981). Tal edad es la del principio del sistema solar, al inicio de la formación de los planetas, por lo que se ha llegado a considerar como el meteorito de mayor antigüedad que ha caído en la Tierra, más antiguo aún que 


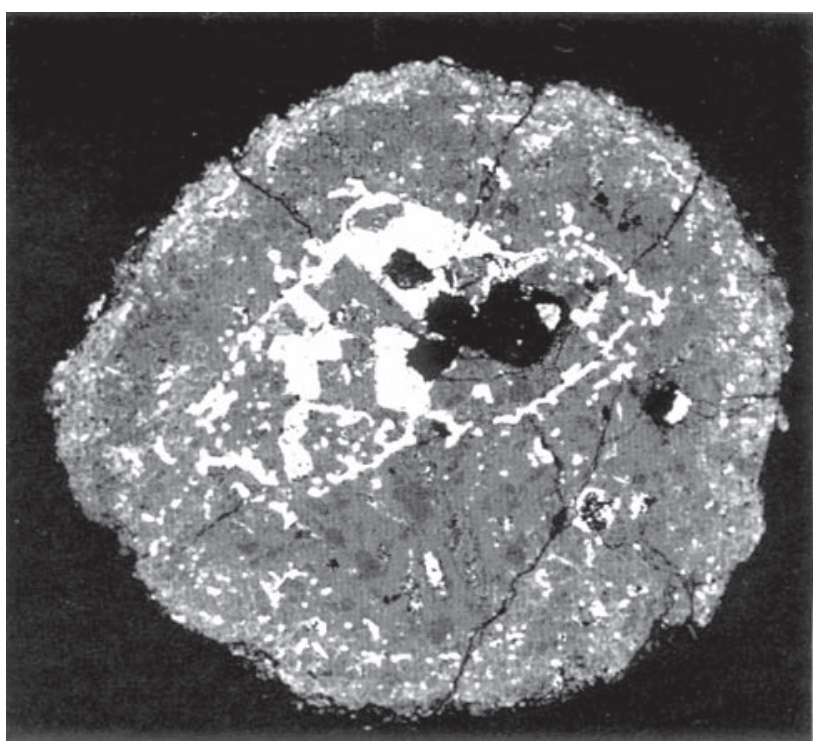

Figura 1. Imagen SEM de un cóndrulo del meteorito Allende. En las inclusiones de calcio y aluminio (CAIs), de color claro, se ha identificado melilita, fassaíta y espinela, con perovskita e hibonita como accesorios. En el material carbonoso, se ha identificado tanto hidrocarburos alifáticos como aromáticos. Tamaño del orden de décimas de milímetro (Tomado de Sánchez-Rubio et al., 2001).

el sistema solar. En el meteorito Murchison fue identificada la síntesis de Streicker, la cual produce aminoácidos e hidroxiácidos en proporción directa a la cantidad de amoníaco presente (Peltzer et al., 1984).

Otro de los meteoritos primitivos más notorios es el meteorito de Tagish Lake (Figura 2), cuya caída en el Yukón, Canadá, el 18 de enero de 2000, fue filmada. Hiroi et al. (2001) consideran, por estudios de reflectancia, que proviene de un asteroide de tipo $\mathrm{D}$, que se ubican en la parte más externa del cinturón de asteroides, considerablemente más fría que la parte interna. En él se ha identificado un tipo sencillo de moléculas orgánicas, sin trazas de aminoácidos, con nanodiamantes y un tipo de carbón, diferente al diamante y al grafito, que es conocido como fullereno, por lo que es considerado como el más primitivo de los meteoritos conocidos, con una edad de 4.5 $\mathrm{Ga}$, y con una línea de evolución química completamente diferente a las de los meteoritos Allende y Murchison (Brown et al., 2000).

Las partículas preservadas de la nebulosa original (granos presolares) constituyen los objetos más antiguos conocidos. Se cree que se hayan formado por condensación de la fase gaseosa que resultó de la explosión de una supernova con aporte de otro tipo de fuente, como las gigantes rojas, las novas o las llamadas AGB (gigantes rojas muy viejas). En el laboratorio, estas partículas se separan de los meteoritos por disolución en ácidos fuertes. Tales partículas consisten en fragmentos pequeños de varios minerales, que en orden descendente de abundancia son los siguientes: (1) Diamantes microscópicos o nanodiamantes, C (cúbico), 2 nanómetros de tamaño; su inusual valor isotópico de Xe sugiere que procedan de una supernova. (2) Carburo de silicio, $\mathrm{SiC}, 0.1-20 \mu \mathrm{m}$; probablemente provienen de estrellas del tipo AGB. (3) Grafito, $\mathrm{C}$ (hexagonal), $20 \mu \mathrm{m}$ en promedio; por las relaciones isotópicas de varios elementos puede provenir de una supernova o de un fuerte viento estelar; contiene inclusiones de $\mathrm{TiC}, \mathrm{FeC}$ y Fe-Ni que sirvieron de núcleos alrededor de los cuales se depositaron capas concéntricas de grafito. (4) Nitruro de silicio, $\mathrm{Si}_{3} \mathrm{~N}_{4}$; han sido hallados sólo unos cuantos granos; se cree que provenga de una supernova. (5) Corindón. (6) Espinela. (7) Rutilo. Estos tres últimos son muy escasos y por ser óxidos se cree que provengan de un tipo de gigante roja vieja, rica en oxígeno. Respecto a los CAIs, cuyo origen fue asignado por SánchezRubio et al. (2001) a la primera etapa de condensación a partir de la nebulosa, como se mencionó antes, esos mismos autores señalan que debido al exceso de ${ }^{26} \mathrm{Mg}$ en tales partículas, elemento que se produce por la desintegración radiactiva del ${ }^{26} \mathrm{Al}$, que a su vez se origina en las supernovas, es probable que los CAIs provengan de una supernova que debe haber estado cercana debido a la corta vida media de este isótopo radiactivo y que probablemente se trate de la misma supernova cuyas ondas de choque colapsaron la nebulosa original, lo que originó la formación del sistema solar. No obstante, pese a que hasta la fecha no se han hallado edades más antiguas que $4.6 \mathrm{Ga}$, cabe la posibilidad de que los CAIs hayan formado parte de la misma nebulosa que dio origen al sistema solar, pero que por su carácter refractario no se hayan evaporado, sobre todo en la zona externa del cinturón de asteroides, donde la temperatura debió haber sido considerablemente menor que en la zona interna de éste; lo mismo podría decirse de la materia

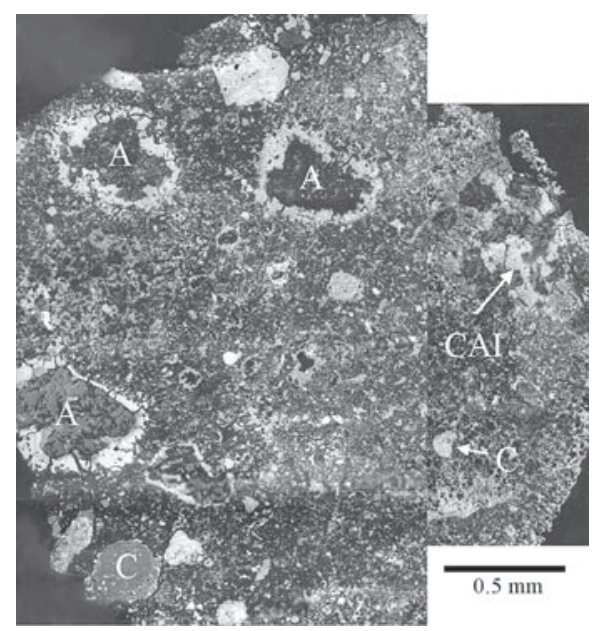

Figura 2. Meteorito de Tagish Lake. Se considera que es el meteorito más primitivo, porque proviene de la fría zona exterior del cinturón de asteroides, en la que el material original de la nebulosa se preservó mejor de la temperatura que vaporizó dicho material en las zonas más cercanas al sol (Tomado de Brown et al., 2000). 
orgánica compleja, la cual, como se expuso anteriormente, ha sido reconocida en las gigantes rojas antiguas, por lo que no puede asegurarse que se formaron durante la primera etapa de formación del sistema solar. Por lo que toca a la parte interna del cinturón de asteroides, lo más probable es que los CAIs sí se hayan volatilizado y que luego se hayan vuelto a formar durante la primera etapa de aglomeración; de acuerdo con esto, la materia orgánica en esta región se formó durante el origen del sistema solar. El material de la nebulosa, cerca de $\operatorname{los} 2,000^{\circ} \mathrm{K}$ y a una presión de una milésima de la presión atmosférica, se encontraba en estado gaseoso, y al enfriarse se condensaron primero los silicatos de calcio y aluminio, seguidos por la aleación de hierro y níquel, y finalmente por los silicatos de magnesio. La secuencia de los principales elementos inicialmente formados se expone en la Tabla 1.

3. En el disco que bordeaba el ecuador de la protoestrella se originaron anillos cuyas partículas coalescieron para formar cuerpos de tamaños diversos. Los asteroides se consideran como representantes de esos cuerpos primigenios; se piensa que no pudieron unirse para formar un planeta por la fuerte atracción gravitacional de Júpiter. Los meteoritos se dividen en pétreos (formados principalmente por silicatos), metálicos y mixtos. Los meteoritos pétreos se dividen, a su vez, en condritos y acondritos; los primeros son los más abundantes y están formados por cóndrulos de alrededor de $1 \mathrm{~mm}$ de diámetro o más pequeños, de composición semejante a la del basalto, con excepción de los condritos carbonosos, que contienen compuestos orgánicos complejos y una cantidad

Tabla 1. Secuencia de minerales en equilibrio condensados de un gas de composición cósmica y a una presión de $10^{-3} \mathrm{~atm}$ (tomada de Turekian, 1972).

\begin{tabular}{|c|c|c|c|}
\hline Mineral & Composición & $\begin{array}{c}\text { Temperatura de } \\
\text { condensación } \\
{\left[{ }^{\circ} \mathrm{K}\right]}\end{array}$ & $\begin{array}{c}\text { Temperatura de } \\
\text { desaparición } \\
{\left[{ }^{\circ} \mathrm{K}\right]}\end{array}$ \\
\hline Corindón & $\mathrm{Al}_{2} \mathrm{O}_{3}$ & 1,758 & 1,515 \\
\hline Perovskita & $\mathrm{CaTiO}_{3}$ & 1,647 & 1,393 \\
\hline Melilita & $\mathrm{Ca}_{2} \mathrm{Al}_{2} \mathrm{SiO}_{7}$ & 1,625 & 1,450 \\
\hline Espinela & $\mathrm{MgAl}_{2} \mathrm{O}_{4}$ & 1,515 & 1,362 \\
\hline Hierro nativo & $\begin{array}{l}\mathrm{Fe}+12.5 \% \\
\text { mole } \mathrm{Ni}\end{array}$ & 1,473 & - \\
\hline Diópsido & $\mathrm{CaMgSi}_{2} \mathrm{O}_{6}$ & 1,450 & - \\
\hline Forsterita & $\mathrm{Mg}_{2} \mathrm{SiO}_{4}$ & 1,444 & - \\
\hline (óxido de titanio) & $\mathrm{Ti}_{3} \mathrm{O}_{5}$ & 1,393 & 1,125 \\
\hline Anortita & $\mathrm{CaAl}_{2} \mathrm{Si}_{2} \mathrm{O}_{8}$ & 1,362 & - \\
\hline Enstatita & $\mathrm{MgSiO}_{3}$ & 1,349 & - \\
\hline Eskolaíta & $\mathrm{Cr}_{2} \mathrm{O}_{3}$ & 1,294 & - \\
\hline Cobalto nativo & Co & 1,274 & - \\
\hline Alabandita & $\mathrm{MnS}$ & 1,139 & - \\
\hline Rutilo & $\mathrm{TiO}_{2}$ & 1,125 & - \\
\hline Feldespato alcalino & $(\mathrm{Na}, \mathrm{K}) \mathrm{AlSi}_{3} \mathrm{O}_{8}$ & $\sim 1,050$ & - \\
\hline Troilita & $\mathrm{FeS}$ & 700 & - \\
\hline Magnetita & $\mathrm{Fe}_{3} \mathrm{O}_{4}$ & 405 & - \\
\hline Hielo & $\mathrm{H}_{2} \mathrm{O}$ & $\leq 200$ & - \\
\hline
\end{tabular}

considerable de agua formando minerales hidratados, como la clorita; se cree que este último tipo proveyó el agua de la Tierra, así como los compuestos orgánicos de los que se originó la vida; los condritos carbonosos constituyen sólo alrededor del $2 \%$ del total de meteoritos identificados. Los acondritos, que son más escasos, carecen de cóndrulos, lo que se atribuye a la desaparición de la textura original debido a metamorfismo por impacto. Los meteoritos metálicos son aleaciones de hierro y níquel que suelen contener glóbulos de FeS (troilita). Los meteoritos mixtos son pétreos con inclusiones de hierro y níquel finamente diseminadas en ellos. Respecto al origen de la Tierra, ésta se formó por coalescencia de cuerpos, los que han sido denominados planetesimales, que pasaron con el tiempo desde tamaño muy pequeño hasta muy grande. La fusión de la Tierra tuvo lugar debido a la concurrencia de cuatro factores: (1) Con el aumento de tamaño de la Tierra y el consiguiente aumento de su atracción gravitacional, se incrementaron los choques, cuya energía cinética se transformó en calor que paulatinamente fue elevando la temperatura del planeta. (2) Relacionado con el proceso de acreción planetesimal, en la generación de calor, está el consecuente aumento de la gravedad, lo que produjo un incremento en la temperatura por contracción en el protoplaneta. (3) Descenso de las partículas de hierro y níquel para formar el núcleo, cuya energía potencial se transformó en energía calorífica. Este proceso, por sí sólo, pudiera haber contribuido con el 50\% del calor necesario para la fusión de la Tierra (Fyfe, 1974). (4) Finalmente, se tiene la energía radiactiva, que debió haber sido importante en esa época debido a un aporte considerable de isótopos de corta vida media. A continuación, en el material fundido tuvo lugar el importante proceso de diferenciación, ya iniciado con la formación del núcleo y seguido con la formación del manto y la corteza.

4. El globo central del protosistema solar estaba sujeto por atracción gravitacional al colapso o implosión de sus partículas hacia el núcleo, lo que traía como consecuencia un aumento en la presión. Finalmente, la presión llegó a ser tan elevada que venció la fuerza de repulsión entre los núcleos de hidrógeno (protones), fusionándolos, con lo que se produjo la ignición o formación del sol. Este evento de fusión termonuclear generó un viento solar que barrió los gases $\left(\mathrm{H}, \mathrm{He}, \mathrm{H}_{2} \mathrm{O}, \mathrm{CH}_{4}\right.$ y $\left.\mathrm{NH}_{3}\right)$ de la primera atmósfera de los planetas interiores, de Mercurio a Marte, dejándolos enriquecidos en silicio y hierro.

5. Los gases barridos de los planetas interiores fueron atrapados por el campo gravitacional de Júpiter que se convierte en el más grande de los planetas y atrae, por consiguiente, la mayor parte de los meteoritos. Esto sirvió, y sigue sirviendo, de protección a la Tierra, porque originó una disminución considerable en la frecuencia de impactos meteoríticos. El planetoide, que se supone del tamaño de Marte, que se cree haya chocado con la Tierra hace $4.45 \mathrm{Ga}$ y que haya desprendido una parte de la misma que se convirtiera en la Luna (Halliday, 2000), es probable que se haya formado en el mismo anillo en el que se encontraba la 
Tierra, con lo que culminó el proceso principal de acreción de este planeta. Tal choque junto con los repetidos impactos meteoríticos pudieron haber causado la fusión repetida de las primeras litosferas.

\section{Formación de la litosfera, la atmósfera y los océanos}

\subsection{Litosfera}

Debido al estado de fusión de la Tierra se produjo, por diferencias de densidad, el evento de diferenciación magmática, de una importancia capital en su evolución. La diferenciación condujo a la formación de un núcleo "interior" de Fe y $\mathrm{Ni}$ en estado sólido, rodeado por una capa, llamada "núcleo exterior", de Fe y Ni fundidos, cuyo borde externo contiene FeS (troilita). La capa siguiente es la del manto inferior, que se define como la zona situada a una profundidad de unos $1,000 \mathrm{~km}$, formado por silicatos con una densidad de $4.7 \mathrm{~g} / \mathrm{cm}^{3}$. Por encima de él, se halla el manto superior, formado por silicatos con una densidad de $3.4 \mathrm{~g} / \mathrm{cm}^{3}$ y composición peridotítica. Al enfriarse la superficie se desarrolló rápidamente una capa sólida, llamada corteza, que está separada del manto superior por la discontinuidad de Mohorovicic, definida por el cambio en la velocidad de las ondas sísmicas $P$ de $7 \mathrm{~km} / \mathrm{s}$ en la corteza inferior, a $8.1 \mathrm{~km} / \mathrm{s}$ en el manto superior. La corteza oceánica tiene un espesor promedio de 10 a $15 \mathrm{~km}$, y la corteza continental de unos $35 \mathrm{~km}$.

En una clasificación por el estado físico, a la capa sólida se le denomina litosfera, la que consiste en la corteza y en la parte más superficial del manto superior. Su espesor es del orden de los $100 \mathrm{~km}$. Debajo de ella se halla la astenosfera (esfera de debilidad), en la cual tienen lugar flujos plásticos que permiten los ajustes isostáticos y en la que pueden generarse los magmas; su cima se puede ubicar por una notable atenuación en la velocidad de las ondas sísmicas. Al empezar a formarse, la litosfera fue continuamente reciclada. Al tiempo tomado entre el inicio de la formación del sistema solar $(4.6 \mathrm{Ga})$ y la primera corteza permanente $(\sim \mathrm{Ga})$, se le conoce como Hadeano o Priscoano.

La edad de formación de la Tierra no puede conocerse con exactitud debido a los repetidos eventos de fusión que ésta ha experimentado, pero puede considerarse como límite superior la edad de los meteoritos más antiguos (Taylor, 1992), como el Allende, que es de $4.56 \mathrm{Ga}$, como ya se mencionó. La Tierra es considerada para esta edad como una esfera de metal y roca fundidos. La roca más antigua conocida es el Gneis Acasta, en la provincia canadiense de Northwestern Territories, con 4,030 Ma (mega-años; $1 \mathrm{Ma}$ $=1 \times 10^{6}$ años) (Bowring y Williams, 1999). No obstante, los zircones son minerales muy resistentes a las altas presiones y temperaturas, así como a la erosión, por lo que han sobrevivido incluso al bombardeo meteorítico intenso que tuvo lugar desde el inicio de la Tierra hasta 4,030 Ma; en virtud de esto, zircones detríticos hallados en depósitos fluviales antiguos metamorfoseados en el terreno del Gneis Narryer, de la región de Jack Hills, distrito Murchison, en Australia occidental, fueron reportados simultáneamente por dos grupos de investigación diferentes, convirtiéndose en los materiales terrestres de mayor antigüedad conocidos:

Por una parte, Wilde et al. (2001) determinaron una edad de 4,404 $\pm 8 \mathrm{Ma}$, por ${ }^{207} \mathrm{~Pb} / 206 \mathrm{~Pb}$ en zircones (Figura 3), cuyo contenido en tierras raras, relación $\delta^{18} \mathrm{O}$ alta e inclusiones de $\mathrm{SiO}_{2}$ indican una fuente magmática granítica. El granito, a su vez, implica la existencia de océanos, puesto que se genera por subducción de un segmento de corteza oceánica con minerales hidratados, lo que abate el punto de fusión de los minerales de tal segmento y permite la formación de magma granítico por fusión parcial y diferenciación magmática. El granito recién formado debe haber constituido inicialmente un arco de islas, que pudo haberse unido ulteriormente, por acreción, a otros arcos de islas graníticos formando una primitiva corteza continental.

El segundo reporte es el de Mojzsis et al. (2001), quienes analizaron un pequeño cristal de zircón en el que obtuvieron un rango de edades de 3,910 a 4,280 Ma y también una relación isotópica $\delta^{18} \mathrm{O}$ alta que los llevó a inferir que se formó en la superficie a temperaturas del orden de los $100^{\circ} \mathrm{C}$, en las que ya era posible la existencia de agua líquida $y$, por ende, de vida.

Las rocas que muestran la evolución más temprana de la corteza son el llamado Complejo Gnéisico Itsaq (Figura 4), que consiste en extensos afloramientos de gneis de composición tonalítico-granodiorítica con cerca del 10\%

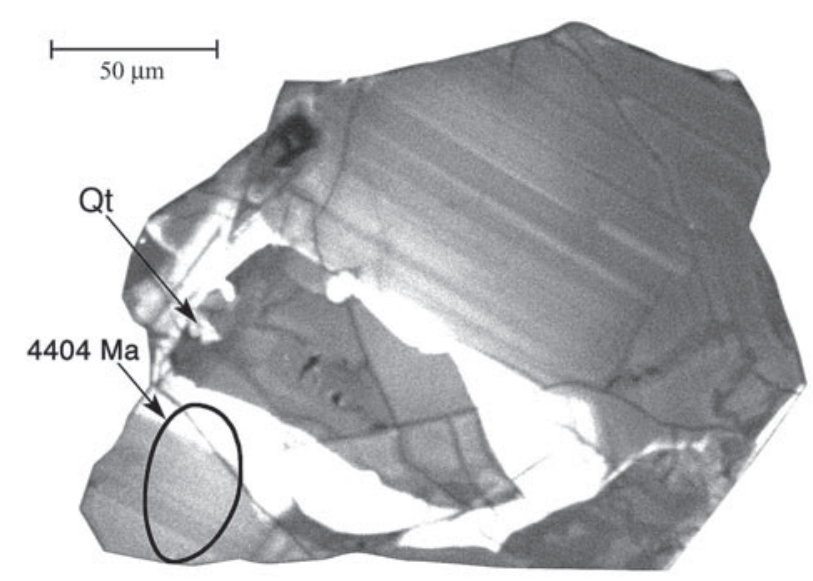

Figura 3. Imagen de catodoluminiscencia del cristal de zircón cuya edad de $4.4 \mathrm{Ga}$ lo hace el material más antiguo actualmente conocido de origen terrestre. Proviene del metaconglomerado Jack Hills, de Australia occidental. Se observan las zonas concéntricas de crecimiento magmático alrededor del núcleo del cristal. La edad de $4.4 \mathrm{Ga}$ fue obtenida, mediante microsonda iónica, en el área encerrada en el círculo. Qt es una inclusión de cuarzo (Fuente: University of Wisconsin-Madison; http:// www.news.wisc.edu/newsphotos/zircon.html). Crédito: John W. Valley. 


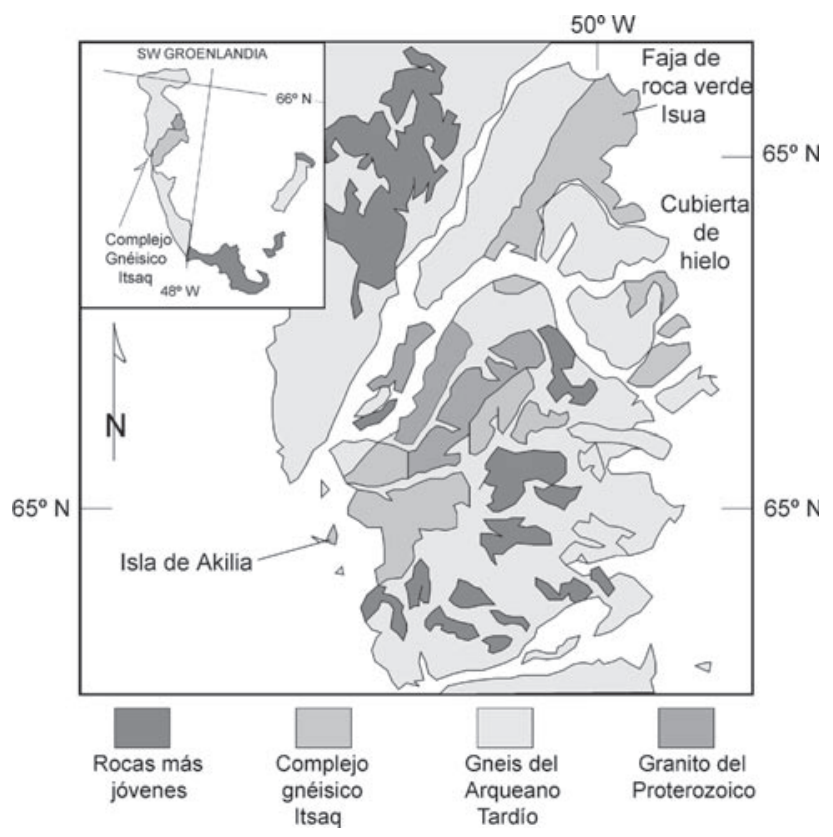

Figura 4. Mapa geológico simplificado del Complejo Gnéisico Itsaq y de las rocas correlativas de la isla de Akilia, del Arqueano Temprano (3,7703,900 Ma) en el suroeste de Groenlandia. Las rocas sedimentarias más antiguas conocidas y los gneises asociados a ellas se hallan a lo largo de la costa. Este conjunto de rocas sufrió la intrusión durante el Proterozoico del Granito Qorqut (Modificado de Nutman et al., 1996).

de enclaves de segmentos de corteza oceánica constituido por anfibolita en la base, cubierta sucesivamente por basalto almohadillado, grauvaca, pizarra, pedernal y la formación de hierro bandeado (Figura 5), conocida como BIF, por las siglas de banded iron formation (Nutman et al., 1996), en el suroeste de Groenlandia. Se piensa que este complejo encierra evidencias geoquímicas de vida (Schidlowski, 1988; Mojzsis et al., 1996), y que ésta haya surgido tan pronto como estuvieron disponibles agua líquida, fuentes de energía y los "ladrillos" representados por moléculas orgánicas (Mojzsis y Harrison, 2000).

Se cree que hubo un período intenso de bombardeo meteorítico sobre la Tierra, el cual ocurrió entre 4.1 y 3.8 $\mathrm{Ga}$ (Ryder, 1992). Para algunos investigadores, el desarrollo de la vida pudo haber sido frustrado por los impactos de grandes meteoritos durante el evento llamado bombardeo intenso tardío, registrado en la Luna con 3.9-3.8 Ga de antigüedad, los cuales alteraron y, en parte, destruyeron este hábitat primitivo. No obstante, en las primeras rocas sedimentarias conocidas hasta ahora, en la localidad de la isla Akilia, con una antigüedad de $3.85 \mathrm{Ga}$ (Nutman et al., 1997), correlativas con la faja de roca verde Isua, no se descubrió anomalía de iridio alguna que probara el supuesto bombardeo meteorítico. Por el contrario, los depósitos de hierro bandeados contenidos en esas rocas mostraron una relación isótopica de carbono enriquecida en ${ }^{12} \mathrm{C}$, que es el isótopo preferido selectivamente sobre el ${ }^{13} \mathrm{C}$ por los microorganismos, tanto en la localidad de Isua como en la de la isla de Akilia (Figura 6). La apatita sedimentaria se considera en esta área como biomarcador, porque se presenta asociada al grafito rico en ${ }^{12} \mathrm{C}$; esto ha llevado a considerar que los organismos hace 3.85 Ga ya eran complejos porque podían utilizar los fosfatos y eran capaces de efectuar tanto la fotosíntesis como la quimiosíntesis (Mojzsis y Arrhenius, 1998). La evidencia isotópica es la única herramienta que permite probar la presencia de vida, pues el metamorfismo que afecta la secuencia destruyó toda evidencia fosilífera y pudo haber formado apatita y grafito epigenéticos por la descomposición térmica de siderita. Para investigar el efecto del metamorfismo sobre los resultados isotópicos que habían sido obtenidos originalmente por Schidlowski et al. (1979), que parecían inválidos debido al metamorfismo, Mojzsis et al. (1996) obtuvieron, con la nueva microsonda iónica de alta resolución de la UCLA, valores isotópicos que confirmaron el enriquecimiento en ${ }^{12} \mathrm{C}$ y, además, analizaron la materia orgánica contenida en apatita, también en depósitos de tipo BIF, en una secuencia similar, pero de 3,250 Ma, en el cratón de Pilbara, en el occidente de Australia, obteniendo valores que cayeron dentro del rango de carbón de origen orgánico. La mencionada faja de roca verde Isua consiste en un arco de sólo $35 \mathrm{~km}$ de largo, pero el descubrimiento de rocas similares en edad y composición, en la localidad de Porpoise Cove, en Quebec septentrional (Figura 7), ha extendido significativamente el área de las primeras rocas volcánicosedimentarias permanentes de la Tierra. Aquí, el basalto resultó con una edad de $3,825 \pm 16 \mathrm{Ma}$, mientras que en Isua la edad es de $3.7 \mathrm{Ga}$, por lo que Porpoise Cove es una localidad correlativa con ella y con la de la isla de Akilia. Se piensa que en la secuencia canadiense también hay carbón de origen orgánico, al igual que se estimó en Isua y en la isla de Akilia, lo cual implica que cuando se formaron las primeras rocas sedimentarias que se han preservado, ya existía vida en la Tierra.

La naturaleza de los supuestos depósitos de tipo BIF de la isla de Akilia ha sido cuestionada por Fedo y Whitehouse (2002a, 2002b), quienes los interpretan como esquistos bandeados cuyo protolito fueron rocas ultramáficas, alterados por un intenso metasomatismo; no obstante, tales autores validan los depósitos de tipo BIF en la faja de roca verde de Isua. Por su parte, Frei et al. (2002) verificaron esa faja concluyendo que la intrusión de las tonalitas tuvo lugar entre 3.81 y $3.74 \mathrm{Ga}$, siendo seguida por una copiosa emanación de fluidos de naturaleza alcalina que produjeron el metasomatismo intenso. Según lo anterior, podría pensarse que la secuencia de la isla de Akilia es diferente de la de Isua, pero el ambiente geológico de ambas es el mismo: el de un arco volcánico, como lo indica la presencia de tonalitas, que representan las raíces del mismo, las cuales produjeron un hidrotermalismo intenso. Dicho arco volcánico debió estar asociado a derrames de lava y a depósitos de origen químico, como los BIFs. En este contexto, es posible que la secuencia de Akilia represente, debido a la erosión, un nivel más profundo que el de la 
secuencia de Isua. No obstante, el artículo de Fedo y Whitehouse fue subsecuentemente cuestionado: Mojzsis y Harrison (2002) estimaron que los datos de Fedo y Whitehouse corresponden a vetas de piroxenita secundaria, que cortan a la secuencia; Friend et al. (2002) opinaron que las rocas de Akilia son derrames de lava máficos (basalto) y ultramáficos (komatiita) alterados, con una unidad interestratificada de rocas sedimentarias; y Palin (2002) afirmó que la distribución de los elementos traza de las bandas estudiadas, excepto una, coincide con los BIFs de Isua y no con rocas ultramáficas.

En cuanto a la composición isotópica ligera del carbono, indicativa de un origen orgánico, van Zuilen et al. (2002) han hecho notar que el grafito se presenta en forma abundante en vetas de carbonatos cuyo origen atribuyen a metasomatismo. El grafito se formaría por descomposición a alta temperatura de los carbonatos. En vez de los valores isotópicos ligeros, esos autores obtuvieron valores bastante menos ligeros y algunos valores ligeros, los que atribuyeron a contaminación con carbono más reciente, por lo que concluyen que el origen del grafito es abiótico. No obstante, se requiere de más estudios que confirmen esas conclusiones.

Si bien las opiniones antagónicas al origen biótico del grafito de Isua son muy dignas de tomarse en cuenta, no consideran que el ambiente de los BIFs es favorable para el origen y evolución de la vida. Existen varias hipótesis sobre la formación de los BIFs, enumeradas por Guilbert y Park (1986), pero, según estos autores, los BIFs del Arqueano son esencialmente de origen hidrotermal. De acuerdo con tal hipótesis, el hierro sería emitido a través de ventilas hidrotermales en el fondo marino y se precipitaría en tres facies diferentes: de sulfuros, de carbonatos y de óxidos (James, 1954). La oxidación de $\mathrm{Fe}^{2+}$ a $\mathrm{Fe}^{3+}$ representa una

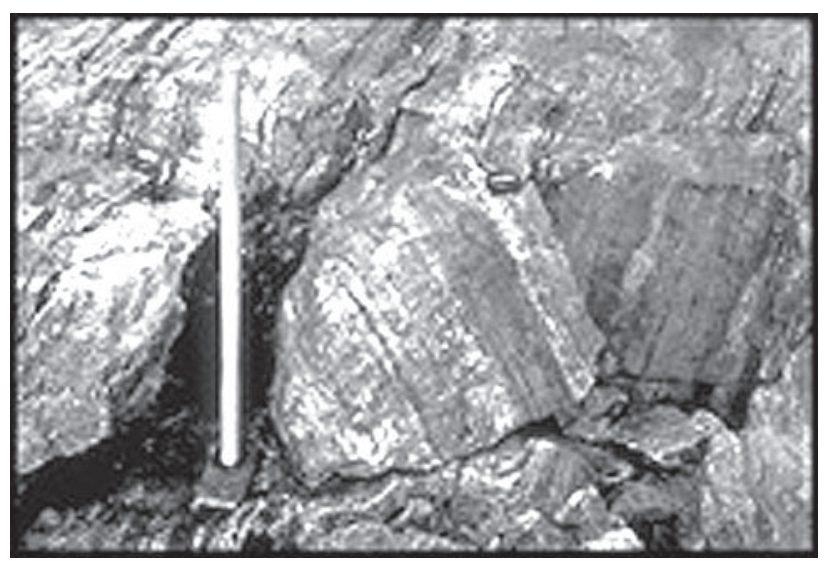

Figura 5. Fotografía que muestra unos bloques de las primeras rocas sedimentarias conocidas, de $3.85 \mathrm{Ga}$, en la isla de Akilia, las que supuestamente contienen BIFs y evidencias geoquímicas de carbono producido por organismos (Fuente: Frontiers Newsletter, http:// www.nsf.gov/od/lpa/news/publicat/frontier/3-97/3rocks.htm, Marzo de 1997; crédito: Allen Nutman). posible forma de respiración, como fue descubierto recientemente (Kashefi y Lovley, 2003), por lo que en ese ambiente podrían haberse originado los primeros organismos o, bien, haber proliferado. Estos organismos, serían capaces de efectuar la quimiosíntesis a partir del $\mathrm{CO}_{2}$ liberando oxígeno, el que precipitaría el hierro en forma de magnetita para producir la primera banda rica en hierro de los BIFs. Al agotarse el $\mathrm{Fe}^{2+}$, aumentaría la cantidad de $\mathrm{O}_{2}$, factores, ambos, que tenderían a hacer que los organismos desapareciesen en su mayoría. Como resultado, se precipitaría una banda de pedernal o de jaspe. Al cesar la producción de oxígeno, la concentración de $\mathrm{CO}_{2}$ empezaría a aumentar, dando lugar al inicio de un nuevo ciclo, que daría origen a nuevas bandas en el BIF. Inclusive, estos ciclos de incremento y disminución en la cantidad de oxígeno podrían ser el mecanismo de evolución darwiniana que seleccionara paulatinamente organismos anaeróbicos cada vez más adaptados al oxígeno, hasta culminar con los organismos aeróbicos.

En contra del modelo abiótico tradicional para las primeras etapas de la Tierra, Ohmoto et al. (2001) proponen un nuevo modelo en el que habría oxígeno en los océanos desde antes de $3.5 \mathrm{Ga}$. Esos autores se basan en el estudio de más de 300 muestras de lutita con materia orgánica cuya edad varía entre 3.5 y $1.9 \mathrm{Ga}$. En esas muestras determinaron las relaciones isotópicas $\delta^{13} \mathrm{C}$ y $\delta^{34} \mathrm{~S}$; además, analizaron el contenido medio y los rangos de concentración de $\mathrm{S}, \mathrm{C}, \mathrm{N}$, $\mathrm{P}, \mathrm{Mo}, \mathrm{U}, \mathrm{V}$ y REE, así como la relación $\mathrm{Fe}^{3+} / \mathrm{Fe}^{2+}$. Con base en esos datos, concluyen que la vida emergió antes de $3.5 \mathrm{Ga}$, con la presencia de bacterias reductoras de sulfatos, cianobacterias y bacterias metanogénicas.

Es digno de mencionar que, respecto a cuándo se formó la corteza, existen dos corrientes de opinión: la tradicional, que considera que la corteza se formó de manera paulatina, hace unos $3 \mathrm{Ga}$, y la que considera que la corteza se formó rápidamente, poco después de la formación del planeta. Esta última fue iniciada por Richard Armstrong al final de la década de 1960, quien la defendió hasta su muerte, en 1991, de los apasionados ataques de los tradicionalistas. Se dice que por ello murió amargado, pero los datos mencionados anteriormente parecen conferirle la razón.

\subsection{Atmósfera}

Se considera que al formarse la Tierra a partir de uno de los anillos de la nebulosa de gas y polvo, hace $4.56 \mathrm{Ga}$, existía una primera atmósfera de los llamados gases cósmicos: $\mathrm{H}, \mathrm{He}, \mathrm{NH}_{3}, \mathrm{CH}_{4}$ y $\mathrm{CO}_{2}$, principalmente. Sin embargo, estos gases fueron difundidos en el espacio debido a la alta temperatura de la Tierra o, bien, fueron barridos por el viento solar (partículas cargadas eléctricamente).

En ese entonces, el panorama era el de un planeta rocoso, estéril y sin atmósfera; sin embargo, el enfriamiento en la superficie debió causar corrientes de convección considerables en el magma del interior que, junto con los 


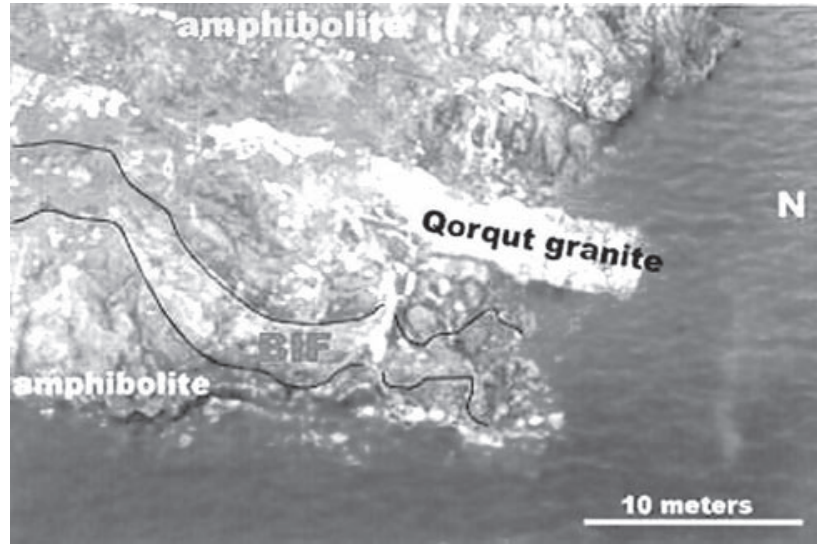

Figura 6. Fotografía aérea de las rocas de la supuesta formación de hierro bandeado (BIF) del Arqueano Temprano en la isla de Akilia. Las rocas metasedimentarias están rodeadas por anfibolitas. Estas rocas sufrieron la intrusión de rocas ígneas, ahora transformadas en gneises, hasta de 3,850 Ma. Se distingue en color claro el intrusivo granítico del Proterozoico. Viendo hacia el este (Modificado de Mojzsis y Harrison, 2000).

frecuentes impactos de meteoritos, debieron fracturar la delgada litosfera inicial, lo que favoreció el vulcanismo y la emisión asociada de gases con una composición que se estima similar a la que tienen ahora: $70 \%$ de vapor de agua, $15 \% \mathrm{CO}_{2}, 5 \% \mathrm{~N}_{2}$ y $5 \%$ de $\mathrm{H}_{2} \mathrm{~S}$, además de $\mathrm{CO}, \mathrm{CH}_{4}, \mathrm{NH}_{3}$, $\mathrm{H}$ y otros gases, con la ausencia de $\mathrm{O}_{2}$, lo que daba un carácter reductor a la atmósfera en esa época (Holland, 1984). Estos gases formaron la etapa inicial de la segunda atmósfera de la Tierra. Uno de los compuestos considerados necesarios para la aparición de moléculas orgánicas complejas, como los aminoácidos, es el HCN, cuya formación es factible en una atmósfera que contiene $\mathrm{CO}_{2}$, $\mathrm{H}_{2} \mathrm{O}$ y $\mathrm{N}_{2}$.

Por lo que toca al oxígeno, dado su alto grado de nocividad para la materia viva, su presencia ha sido muy debatida. Debido a que no existía la capa protectora de ozono, al incidir la radiación solar, principalmente la ultravioleta, sobre las moléculas del vapor de agua en la parte superior de la atmósfera, las disociaban en átomos de hidrógeno y de oxígeno; este fenómeno es conocido como fotólisis. El hidrógeno, por ser un gas muy ligero, se escapa hacia el espacio, pero el oxígeno permanece y sus átomos se unen en moléculas de $\mathrm{O}_{2}$, que tienden a descender hacia la superficie. Aunque el oxígeno producido por fotólisis es escaso, existe una corriente de opinión que considera que su presencia disminuyó el carácter reductor de la atmósfera lo suficiente para que ésta no fuera favorable para la formación de la vida. En contra de lo anterior, Harold C. Urey, quien propuso ese fenómeno desde 1952, consignó que, como resultado del mismo, se generaría una capa de ozono que serviría de escudo contra la radiación ultravioleta (Antonio Lazcano, comunicación escrita, 4 de octubre de 2003), lo que reduciría la subsiguiente formación de oxígeno y protegería a los compuestos orgánicos. En favor de un ambiente reductor está la llamada "paradoja del sol joven". Para resolver esta última, se requiere de la presencia de gases de invernadero, que son estables en un ambiente reductor. Como el $\mathrm{CO}_{2}$ reacciona para formar carbonatos, se ha considerado que debió haber habido $\mathrm{CH}_{4}$ y NH son inestables en ambiente oxidante. No obstante, la existencia de un sol menos brillante, postulado por la paradoja mencionada, ha sido objetada por Günther Wuchterl y Ralf S. Klesser, quienes, mediante simulación en computadora del proceso de acreción del protosol, concluyeron que éste, aún antes del inicio de las reacciones de fusión nuclear, era dos veces más brillante que el sol actual debido a la energía liberada por la acreción de las partículas que lo formaron (Schilling, 2001).

Respecto al nitrógeno, la idea tradicional es que su presencia en la atmósfera se debía al proceso de desgasificación del manto. No obstante, se ha mostrado mediante estudios de isótopos de nitrógeno que en el Arqueano el nitrógeno era rico en ${ }^{15} \mathrm{~N}$, mientras que el nitrógeno del manto está empobrecido en dicho isótopo. Por esto, se ha propuesto que el nitrógeno de la atmósfera haya sido suministrado por meteoritos carbonosos (Jia y Kerrich, 2002).

\subsection{Océanos}

Al empezar a enfriarse la corteza, el vapor de agua de la atmósfera se condensó en la parte superior de la atmósfera para originar las primeras nubes y, después, una lluvia que duró miles de años. Al principio, debido a las altas temperaturas, las gotas de agua no alcanzaban a tocar la superficie, sino que se evaporaban antes, tal como acontece en algunos desiertos actualmente. La evaporación contribuyó a acelerar el enfriamiento hasta alcanzar el punto en que se formaron los primeros torrentes y, finalmente, los océanos. Las lluvias arrastraron a las aguas oceánicas una parte de los volátiles que se hallaban en la atmósfera, principalmente $\mathrm{CO}_{2}$, que les dio un carácter ácido, y una parte del exiguo $\mathrm{O}_{2}$. La lixiviación en los primeros continentes y el aporte hidrotermal submarino produjeron una alta concentración en $\mathrm{Fe}^{2+}$ (Holland, 1984).

Un grupo de investigadores del Carnegie Institution of Washington, mediante experimentos a temperaturas de 300$800^{\circ} \mathrm{C}$ y presiones de $0.1-0.4 \mathrm{GPa}$, representativas de los sistemas hidrotermales submarinos, mostró que el $\mathrm{N}_{2}$ procedente de la atmósfera pudo haber sufrido una reducción a $\mathrm{NH}_{3}$ dentro de estos sistemas por efecto de la acción catalítica de los minerales hidrotermales (Brandes et al., 1998). Por otra parte, ha sido considerado que, mediante este mecanismo de intercambio con la atmósfera, el amoníaco hidrotermal, además de su rol esencial en la síntesis orgánica, podría haberse sumado al amoníaco atmosférico para resolver la llamada "paradoja del sol joven", como fue propuesto por Sagan y Chyba (1997). Según estos autores, el amoníaco de la atmósfera (originado 


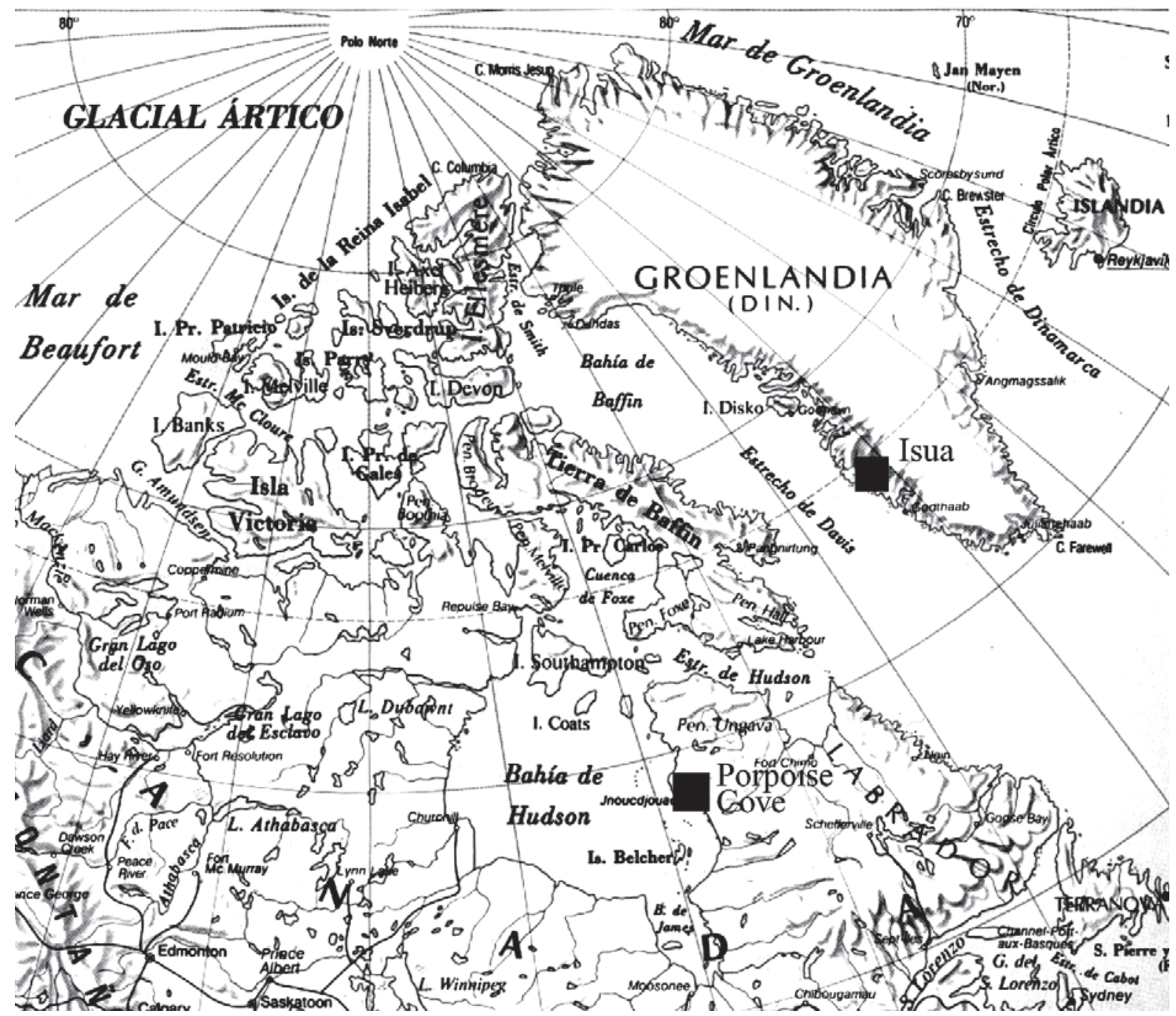

Figura 7. Mapa geográfico en el que se muestra la localidad de Porpoise Cove, Canadá, donde fueron descubiertas rocas del Arqueano Temprano correlativas con las de Isua, Groenlandia, localidad también señalada.

por fotólisis del metano), protegido, debido a que es inestable, de la radiación ultravioleta por un escudo de partículas orgánicas sólidas a gran altitud, habría contrarrestado, por el "efecto invernadero", la deficiencia en calor del sol primitivo, que habría tenido sólo un 70\% de su brillo actual, lo cual habría conducido a un congelamiento de la mayor parte de la Tierra, irreversible porque el hielo habría reflejado una parte sustancial de la radiación solar.

\section{Líneas de pensamiento sobre el origen de la vida}

Las diversas hipótesis acerca del origen de la vida han sido objeto de reseñas muy completas. Entre ellas, se destacan las de Farley (1977), Fry (2000), Strick (2000) y Keller (2002). La Enciclopedia Británica las agrupa en cuatro líneas principales de pensamiento, aunque algunas de las hipótesis involucran conceptos que comprenden dos de ellas:

1. Creación sobrenatural: Más allá de la explicación científica. Los primeros registros de las más antiguas culturas que hacen referencia al origen de la vida son de tipo religioso, como las tablillas de arcilla babilónicas; los jeroglíficos en los templos del antiguo Egipto; el ZendAvesta persa; el Génesis judío; el Popol-Vuh y el Chilam Balam mayas; o el códice Vaticano, en el que se registra la cosmogonía azteca.

2. Generación espontánea: La materia viva se forma a partir de materia no viviente, tanto en el pasado como en el presente. Estas ideas tienen su primer registro en la antigua Grecia y predominaron durante más de dos mil años.

3. Eternidad de la vida: La vida es una cualidad inherente de la materia y ambas han existido siempre. En esta categoría entra la hipótesis de la panspermia así como las ideas creacionistas de algunas religiones. 
4. Generación espontánea en la Tierra primitiva: Diverge de la generación espontánea al considerar que la vida se generó gracias a las condiciones particulares imperantes solamente en la primera etapa de la Tierra.

\section{Línea 1: Creación sobrenatural}

Las hipótesis de la creación de la vida de índole teológica consisten, en general, en la existencia eterna de la materia en un estado elemental y en reposo, la que es activada por el espíritu divino a través de una segunda persona, creada por su amor. Así, en la mitología egipcia de la creación se relata que en el principio de los tiempos existían Ptah, el Dios Eterno, y Nun, las Aguas Primordiales, estáticas y en tinieblas. Ptah concibió en su corazón a Atum y lo creó al pronunciar su nombre. A su vez, Atum creó la tierra, la luz y la vida. Este hecho es representado por un jeroglífico en el que el ave Fénix, que representa a Atum, emerge de las aguas primordiales posada sobre un montículo, lo que simboliza la formación de la materia densa. El mito de que el ave Fénix renace periódicamente de sus cenizas pudiera significar el carácter cíclico y eterno de la creación.

El Génesis (1:1-2) dice: En el principio cuando Dios empezó a crear los cielos y la tierra, la tierra no tenía forma, las tinieblas se extendian sobre el abismo y el espiritu de Dios se movía sobre las aguas. En el Nuevo Testamento, la creación está a cargo de la Segunda Persona: En el principio era el Verbo, y el Verbo era con Dios, y el Verbo era Dios. Este era en el principio con Dios. Todas las cosas por Él fueron hechas, y sin Él nada de lo que ha sido hecho fuera hecho (San Juan 1:1-3).

En el hinduismo se consigna: Entrando en la naturaleza material, la cual es Mi energía, una y otra vez Yo creo el orden cósmico entero, junto con todas las especies de vida (Bhagavad-Gita, 9:8). Según la cita anterior, en esta filosofía, la materia y la vida son creadas simultáneamente, en ciclos que se repiten por toda la eternidad. Al final de cada ciclo, la materia se diluye y la vida es aniquilada. Además, en el momento de la creación de cada ciclo, las diferentes especies que aparecerán están ya predeterminadas. La materia, que existe en un estado elemental antes del acto de creación, recibe el nombre de Maya. El Dios único tiene una personalidad que crea el universo, llamada Vishnú. En el momento de la creación, la materia queda imbuida de una energía $(\mathrm{kal})$, identificada con el tiempo, que guía la evolución del universo: "El factor Tiempo es la Suprema Personalidad de Dios, que da lugar a la creación mediante la agitación de la neutral e inmanifestada naturaleza" (Srimad Bhagavatam 3:26:17).

En la antigua Grecia, en la Argonáutica de Apolonio de Rodas, se consigna que Orfeo cantaba que en el principio de las cosas estaba el Amor (Eros) en el seno del Caos, por lo que era el más antiguo de los dioses y perfecto en sí mismo. Caos significaba materia informe (tal palabra fue convertida en la moderna palabra gas, por van Helmont, por transliteración fonética al flamenco, hacia el año 1630, según el diccionario etimológico Corominas). Hesíodo, en su Teogonía, difiere un tanto de la tradición órfica, y hace surgir del Caos a la Tierra (Gea) y al Amor. Por su parte, en el Fedro, Platón también dice que el Amor es el más antiguo de los dioses y que no debe confundirse con el otro Eros, el hijo de Afrodita, el Cupido romano. Un concepto similar, pero desligado de la mitología, es el del nous de Anaxágoras, la mente universal que impregnaba toda la materia del universo.

El Popol Vuh dice: "Esta es la relación de cómo todo estaba en suspenso, todo en calma, en silencio; todo inmóvil, callado, vacía la extensión del cielo... Llegó aquí, entonces, la Palabra; vinieron juntos Tepeu y Gucumatz en la oscuridad, en la noche".

En el Chilam Balam se consigna: "Todo fue creado por nuestro Padre Dios y por su Palabra; allí donde no había ni cielo ni tierra estaba su Divinidad, que se hizo una nube sola por sí misma, y creó el universo".

En la cosmogonía azteca, el dios creador es Ometecuhtli. El significado etimológico de este nombre es "Señor Segundo", después del dios eterno, Ayamictlan. Ometecuhtli también es identificado como Tonacatecuhtli (el señor de la abundancia) y su esposa, Tonacacíhuatl, lo que recuerda a la teogonía griega. La introducción al culto de esta pareja se atribuye a Quetzalcóatl, como rey. Ambas deidades son unificadas bajo el nombre de Ometéotl, "dualidad generadora y sostén del universo" según Miguel León Portilla.

En la época moderna predarwinista, el Creacionismo tuvo como destacados exponentes a John Ray (1628-1705), considerado como el "Padre de la historia natural" en la Gran Bretaña, y a William Paley (1743-1805), quien fuera maestro de Darwin. Paley expuso, en 1802, sus ideas acerca del origen de la vida mediante la llamada metáfora del relojero: "Los organismos vivientes son más complejos que relojes, en un grado que excede todo cálculo. ...Sólo un Diseñador Inteligente pudo haberlos creado, tal y como un relojero inteligente puede hacer un reloj”.

\section{Línea 2: Generación espontánea}

Aristóteles sostenía la hipótesis de la generación espontánea o abiogénesis, según la cual ciertos animales y plantas se originaban a partir de materia sin vida, tanto en el pasado como en el presente. Esta idea tuvo vigencia hasta que el químico francés Louis Pasteur, en 1864, demostró que era errónea debido a una controversia con el bacteriólogo F. A. Pouchet, quien defendía la generación espontánea. Sin embargo, con anterioridad a él, el biólogo italiano Francesco Redi, en el siglo XVII, ya había descubierto que las larvas en la carne provenían de huevecillos de mosca, y el sacerdote italiano Lazzaro Spallanzani, en el siglo XVIII, ya había demostrado que en frascos herméticamente cerrados que contenían caldo de 
carne no aparecían microorganismos, mientras que en frascos que no estaban bien cerrados sí lo hacían. Los últimos vestigios de la generación espontánea fueron erradicados definitivamente por el físico irlandés John Tyndall, en 1876, quien señaló que los microbios observados en algunas infusiones, después de hervirlas, se debían a la presencia de esporas, que pueden resistir temperaturas elevadas durante períodos prolongados. No obstante, la hipótesis sobre el origen químico de la vida, vigente en la actualidad, y que fuera defendida por el mismo Tyndall, no es otra cosa que la generación espontánea retrocedida en el tiempo (Farley, 1977).

\section{Línea 3: Eternidad de la vida}

\subsection{Hipótesis de la ascendencia cósmica}

\subsubsection{Anaxágoras de Clazómenes (570-500 a.C.)}

Discípulo de Anaximandro y originario del norte de la Jonia, la rama del conocimiento que atraía a Anaxágoras era la astronomía. En consecuencia, situó el origen de la vida en la esfera celeste, por lo que se le puede considerar como el precursor de la hipótesis extraterrestre. En su época, cayó un meteorito del tamaño de un vagón de ferrocarril, al que calificó como proveniente del sol, concepto revolucionario en ese entonces ya que las zonas celestes se creían incorruptibles. Debido a estas ideas, aunadas a su concepto del Nous como divinidad única que se encontraba en todas las cosas y que se oponía al politeísmo oficial, fue perseguido y condenado a muerte, de la que lo salvó su influyente discípulo Pericles.

\subsubsection{Friedrich Wöhler (1800-1882)}

La identificación en meteoritos condríticos carbonosos de hidrocarburos, ácidos grasos, aminoácidos y ácidos nucleicos, entre otros componentes orgánicos, reforzó la posibilidad de que la vida haya llegado a la Tierra en meteoritos. La primera identificación de materia orgánica se atribuye a Berzelius, el más connotado químico de su época, en 1834, en el meteorito Alais, quien atribuyó correctamente el origen de tal materia orgánica a procesos inorgánicos; no obstante, su discípulo Wöhler, quien también identificara materia orgánica en meteoritos en 1858, adscribió su origen a vida extraterrestre, lo que pareció ser reforzado por el analista francés S. Cloëz, quien identificó sustancias parecidas al lignito.

El meteorito Orgueil, caído en forma de varios fragmentos en la localidad francesa del mismo nombre el 14 de mayo de 1864, ha suscitado renovadas polémicas. Casi inmediatamente después de caído fue analizado por Cloëz, quien identificó materia orgánica de la que comentó que "parecería indicar la existencia de sustancias organizadas en cuerpos celestiales". Más tarde, renombrados químicos, entre ellos Berzelius de nueva cuenta, quien era partidario de la síntesis química estelar, confirmaron la presencia de materia orgánica. En esa época, Pasteur, que acababa de demostrar la falsedad de la hipótesis de la generación espontánea, sacó una muestra del interior del meteorito en un ambiente esterilizado, a la que inoculó un fluido con sustancias orgánicas para observar si se manifestaba la presencia de microbios nativos en la muestra, obteniendo resultados negativos. En 1961, Nagy, Hennessy y Meinschein determinaron la presencia de hidrocarburos parafínicos, similares a los de origen animal, como los de la mantequilla; concluyeron que "procesos biogénicos tienen lugar en regiones del universo más allá de la Tierra”. Un nuevo análisis del meteorito Orgueil, hecho con equipo moderno, mostró que la materia orgánica consistía principalmente sólo en los sencillos aminoácidos glicina y beta-alanina; la relación isotópica de carbono mostró que dicha materia no proviene de contaminación terrestre, sino que ésta debió formarse en el espacio por síntesis química (Ehrenfreund et al., 2001). En el mismo estudio fue analizado, con resultados similares, el meteorito Ivuna, que cayó en Tanzania en 1938. Se concluyó que estos aminoácidos probablemente se formaron a partir de $\mathrm{HCN}$, el que ha sido identificado en los cometas, como el HaleBopp, por lo que se concluyó que este tipo de meteoritos corresponde a cometas. Por otra parte, se hizo el análisis de los meteoritos Murchison (caído el 28 de septiembre de 1969 en Australia) y Murray, habiéndose identificado más de 70 aminoácidos. Estos últimos meteoritos se han asignado a un segundo grupo que se ha supuesto proveniente del cinturón de asteroides (Encyclopedia of Astrobiology, Astronomy, and Spaceflight). Cooper et al. (2001) identificaron en el meteorito Murchison polioles, producto de la degradación de azúcares, relacionados con la ribosa y desoxirribosa, lo que ha puesto de manifiesto la existencia de la síntesis de azúcares en ambientes prebióticos, paso de suma importancia en el problema del origen de la vida (Antonio Lazcano, comunicación escrita, 4 de octubre de 2003).

\subsection{Panspermia}

La panspermia consiste en el proceso mediante el cual la vida es llevada al azar de sistema solar a sistema solar y de planeta a planeta. Aunque la hipótesis fue enunciada con tal nombre por Arrhenius, se debe reiterar que la idea original es de Anaxágoras. El interés en la panspermia fue renovado por la identificación de hidrocarburos policíclicos aromáticos (PAHs) en el meteorito Allende, caído en el poblado de este nombre en el estado de Chihuahua, el 8 de febrero de 1969, que consiste principalmente en cóndrulos de olivino.

\subsubsection{Svante August Arrhenius (1859-1927)}

El químico sueco Arrhenius propuso, en 1903, la teoría de la panspermia (semillas en todas partes), según la cual la vida no se originó en la Tierra sino que provino del espacio 
exterior en forma de esporas que viajan por todo el espacio impulsadas por la presión ejercida por la radiación proveniente de las estrellas.

Cabe mencionar que Arrhenius fue el autor de la teoría de la disociación iónica, según la cual un compuesto (soluto) al entrar en solución en un solvente se separa en átomos cargados positiva o negativamente, la que propuso en su tesis doctoral, en 1884. Este concepto, hoy completamente aceptado, en su época fue criticado severamente, estando su tesis a punto de ser rechazada, ya que aún no se había hecho el descubrimiento del electrón, como tampoco el del protón. En 1903, recibió el premio Nobel de Química y en 1905 fue nombrado director del Instituto Nobel de Fisicoquímica. En la actualidad se le considera el fundador de esta última disciplina.

\subsubsection{J. D. Bernal (1901-1971)}

El físico irlandés J. D. Bernal, en su conferencia "Las bases físicas de la vida", dictada en 1947, misma en la que contemplaba la función de las arcillas en el origen de la vida, dejaba abierta la posibilidad de que, dada la limitación de las condiciones terrestres, la vida hubiera llegado desde el espacio, aunque por ese entonces consideraba esta cuestión como meramente teórica. Sin embargo, más adelante, en 1952, en una conferencia en la Sociedad Interplanetaria Británica, consideraba que: "La biología del futuro no estaría confinada a nuestro planeta, sino que tomaría el carácter de cosmobiología". Más tarde, al reconocerse la presencia de materia orgánica en el meteorito Orgueil, afirmó que para explicar tal hecho existían tres causas posibles: (1) contaminación terrestre; (2) origen inorgánico en el sistema solar primitivo, lo que haría posible que las sustancias orgánicas utilizadas para la síntesis del primer organismo tuvieran como fuente los meteoritos; o (3) presencia de vida en el cuerpo del cual se derivó el meteorito (Bernal, 1961).

\subsubsection{Fred Hoyle (1915-2001)}

En los tiempos actuales, uno de los más destacados adeptos de la panspermia ha sido el astrofísico inglés, Sir Frederick Hoyle, quien acuñara, no sin cierta ironía, el nombre de "teoría del big bang", en vez de la cual propuso, junto con Thomas Gold y Hermann Bondi, que el universo no tenía principio ni tendría fin (steady-state theory). Consideró que la materia orgánica compleja detectada en forma de nubes en el espacio interestelar (Hoyle y Wickramsinghe, 1977) pudo haber jugado un papel importante en el origen y desarrollo de la vida no sólo en la Tierra, sino en cualquier parte de la galaxia. También, supuso que en tales nubes pudiera haberse desarrollado la vida, llegando a plantear que algunos tipos de virus se hayan originado de esta manera.

\subsubsection{La controversia actual sobre la vida en Marte}

Recientemente se ha desatado una gran controversia a raíz del hallazgo realizado por McKay et al. (1996) de hipotéticas bacterias fósiles, más pequeñas que las terrestres, en el meteorito Allan Hills (ALH84001), caído hace unos 13,000 años en la Tierra Victoria, en la Antártida (Figura 8). Este grupo de investigadores basa su aseveración en la conjunción de cuatro evidencias:

1. Compuestos orgánicos: Fue reconocida la presencia de sustancias orgánicas complejas, de las conocidas como PAHs, de las que existe un gran número tanto en granos de polvo cósmico como en meteoritos, donde su génesis se presume abiótica, así como en la Tierra, de origen biótico, pero en una asociación que corresponde a la descomposición de microorganismos. Las opiniones adversas sostienen que esto se debe a contaminación, aunque se les ha respondido que la asociación es diferente a las de origen terrestre.

2. Una asociación mineral en desequilibrio: A los lados de la materia orgánica se hallan glóbulos de carbonatos de unos $50 \mu \mathrm{m}$ de diámetro, que pudieran ser microfósiles de bacterias primitivas, en cuyos núcleos predomina el Mn, mientras que en los anillos que los rodean predomina el Fe. Los glóbulos están circundados por líneas oscuras de sulfuros de hierro, magnetita y pirrotita (Figura 9). A favor, se aduce que esta asociación es similar a la producida en la Tierra por bacterias primitivas, y que tal diversidad mineralógica en espacio tan reducido es improbable en un ambiente abiótico.

3. Nanofase de cristales de magnetita (tamaños del orden de $10^{-9} \mathrm{~m}$ ), semejante a las producidas por bacterias terrestres.

4. Presencia de estructuras con forma de bacteria: Entre éstas se halla la famosa fotomicrografía del "gusano marciano" (Figura 10).

El hecho de que de un grupo de 12 meteoritos que se

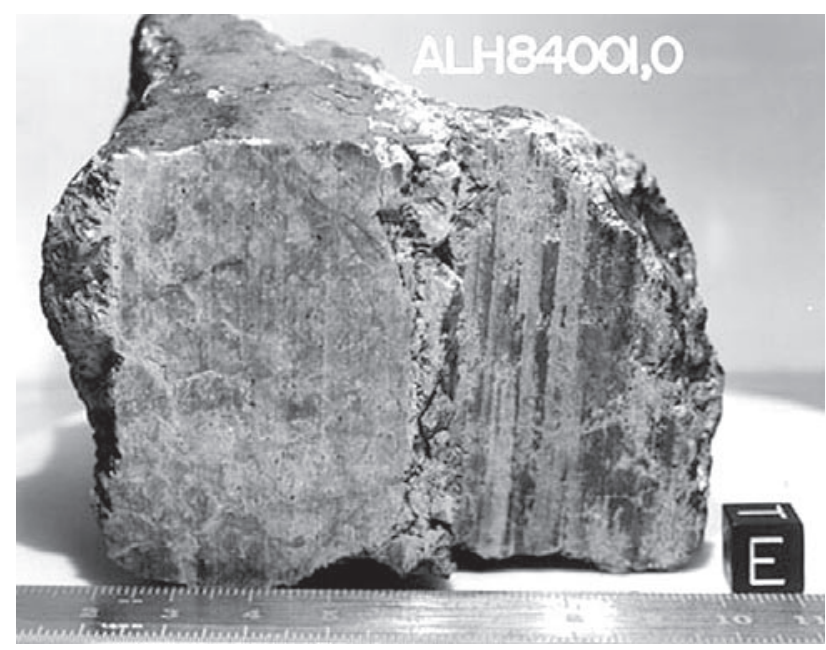

Figura 8. Fotografía del famoso meteorito ALH84001, que se considera procedente de Marte, caído en la región de Allan Hills, de la Tierra Victoria, Antártida. Se muestran las superficies de corte; las estrías son debidas a fricción ejercida por la cortadora (http://www-curator.jsc.nasa.gov/curator/ antmet/marsmets/alh84001/alh84001,0-saw.htm). 


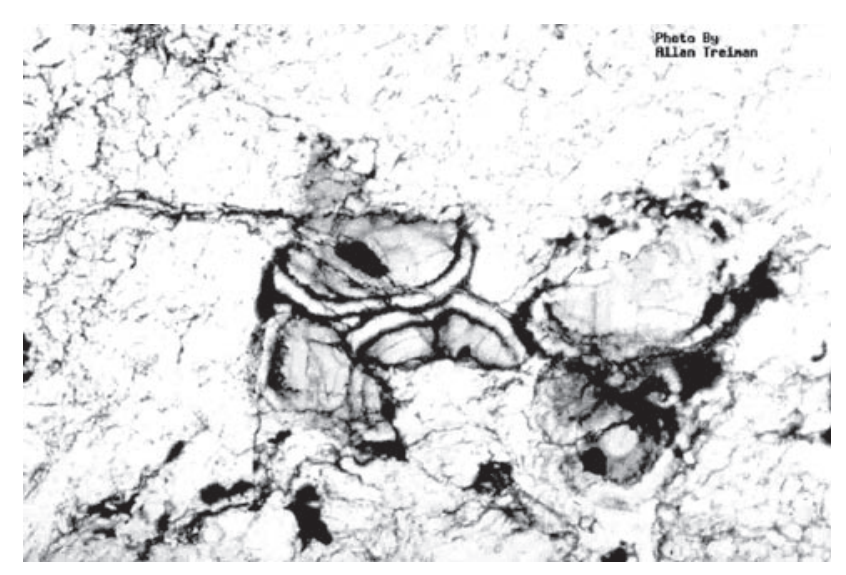

Figura 9. Imagen de microscopio electrónico de barrido (SEM) de diminutos ovoides de 20-100 nm, que se aduce sean bacterias, pero que resultan unas 100 veces más pequeños que las bacterias terrestres. Meteorito ALH-84001 (Tomado de McKay et al., 1996).

presume sean marcianos por sus relaciones isotópicas, el ALH84001 sea el único cuya edad se remonta a $4.5 \mathrm{Ga}$, mientras que el resto tiene una edad de menos de $1.3 \mathrm{Ga}$, ha conducido a que se le considere como condrito carbonoso (con materia orgánica abiótica) formado en el cinturón de asteroides, que haya caído en Marte, de donde habría sido eyectado por el fuerte impacto de un meteorito grande. El hecho de que la materia orgánica se encuentre en fracturas mineralizadas sugiere que se haya formado en un ambiente hidrotermal, que también es propio de los asteroides.

\section{Línea 4: Generación espontánea en la Tierra primitiva}

Las hipótesis científicas sobre el origen de la vida se iniciaron en la antigua Grecia. Infortunadamente, gran parte de las obras pertenecientes a la época más antigua se perdió y sólo se tienen fragmentos de ellas o el testimonio dado por otros pensadores o historiadores. El genio griego tuvo su desarrollo en varias etapas (Vega, 1970):

En la primera de ellas, surgida en la Jonia durante los siglos VI y V a.C., las antiquísimas tradiciones mitológicas fueron racionalizadas por Tales, por su discípulo, el egregio Anaximandro, y por Anaxímenes, en Mileto, que se convirtió así en el primer centro intelectual moderno, y por Heráclito y Anaxágoras, en Éfeso.

La segunda etapa tuvo lugar en la Magna Grecia (Sicilia y el sur de Italia), al ser conquistada Mileto por los persas en 494 a.C., donde enseñaba Pitágoras, reputado como uno de las mayores genios de la antigüedad, pero quien tenía como norma el no escribir. Sin embargo, este lugar resultó no ser un lugar propicio para el desarrollo de la filosofía y Pitágoras murió quemado, junto con sus discípulos, dentro de su escuela en un levantamiento popular contra ellos. Derivada del pitagorismo surgió la escuela atomista, cuyos principios fueron aplicados al origen de la vida por Demócrito.

La tercera etapa corresponde a la de los sofistas, que aglutinaron las teorías anteriores en un modo de pensamiento ecléctico. Con ellos dio inicio la divulgación de los conocimientos científicos.

La cuarta etapa es la de la escuela ateniense, en la que destacan Platón y Aristóteles. Las ideas de este último, por su rigor científico y por el prestigio personal del mismo tuvieron, hasta hace relativamente poco tiempo, una gran influencia en el desarrollo de la ciencia.

\subsection{La escuela jónica}

Bien puede decirse que la ciencia, en su sentido moderno, tuvo sus inicios en Mileto, ciudad de la Jonia antigua, situada en la costa mediterránea de la actual Turquía. Esto se atribuye a su posición geográfica, como uno de los centros de comercio del mundo de esa época. Los filósofos milesios se catalogan aquí dentro de esta línea debido a que consideran el origen de la vida a partir de las sustancias consideradas como más simples en su tiempo.

\subsubsection{Tales (624?-546 a.C.)}

Aunque no sobrevivieron sus escritos, Tales de Mileto fue reconocido por Aristóteles como el primero en considerar un universo creado por causas naturales en vez de por actos divinos y en atribuir el origen de la vida a partir de lo inanimado (Enciclopedia Británica). A partir de la leyenda, según la cual la creación se atribuye a los titanes de la mitología griega Océano y Tethys, antes de la aparición de los dioses del Olimpo, Tales postuló que la vida, así como el universo entero, se había formado a partir del agua. No obstante el cariz científico de sus ideas, Tales aún era partícipe de la filosofía y por ello consideraba al agua como imbuida de un principio activo que permitía su transformación en otras sustancias, así como la creación de vida.

\subsubsection{Anaximandro (610-543 a.C.)}

Aunque discípulo de Tales, en Anaximandro la mentalidad científica ya es completa. A él se le reconoce como el primero en dibujar un mapa de la Tierra. Como materia primordial, él postuló una sustancia difusa e indeterminada, diferente de los elementos conocidos, a la que atribuyó, por primera vez, la cualidad de ser infinita; por toda la eternidad, de ella se separaban fuego y aire de los cuales se generaban, subsecuentemente, tierra y agua, con lo que los mundos nacían y a ella volvían al morir éstos necesariamente. A dicha sustancia la llamó ápeiron (en griego, sin límites). Esta sustancia dio origen al concepto del éter, que permaneció vigente en la ciencia hasta principios del siglo XX, cuando fue desacreditado por el clásico experimento de Michelson-Morley. Un concepto similar, no obstante, es postulado por la moderna astrofísica 


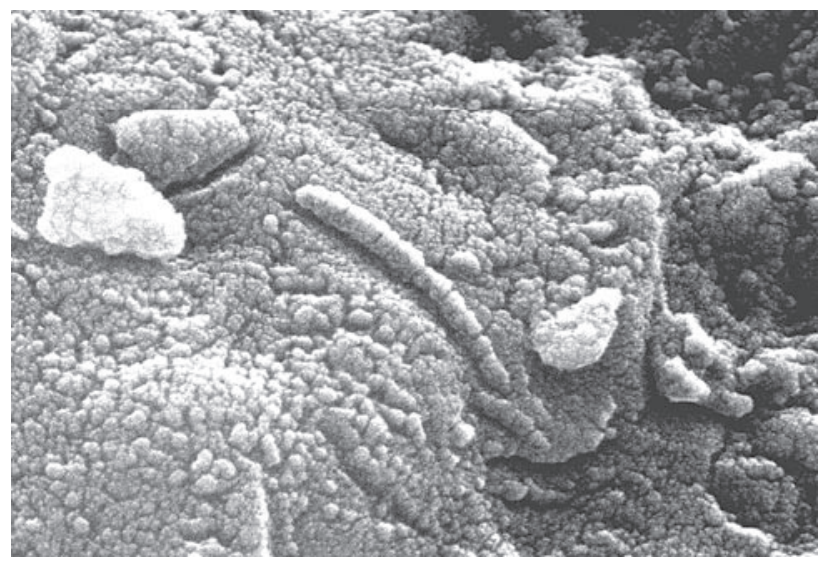

Figura 10. Fotomicrografía de una supuesta bacteria alargada, considerada como de Marte. Meteorito ALH84001 (Tomado de McKay et al., 1996).

al descubrir la materia oscura, que representa el $90 \%$ de la materia del universo, a la que se asocia una misteriosa energía oscura que, a manera de antigravedad, produce en aquélla una aceleración que causa la expansión del universo y que después ocasionará un big crunch, parte de una eterna oscilación entre expansión y contracción del universo. Otra corriente de opinión, fatalista, sostiene que la expansión no podrá ser contrarrestada y que, debido a ella, dentro de $22 \mathrm{Ga}$, los átomos y aun las partículas subatómicas estallarán al cesar de actuar las fuerzas que los unen, evento al que han denominado Big Rip (Caldwell et al., 2003). Resulta paradójico que esta última, la hipótesis más novedosa, coincida con la más antigua, la antiquísima cosmogénesis del hinduismo, según la cual, al final del universo, la materia, impulsada por una energía (también primordial y siempre coexistente con la materia), a la que identifican con el tiempo, retorna a su primigenio estado fundamental (maya), para posteriormente iniciar un sucesivo ciclo de creación por voluntad divina: "El universo entero...está por completo bajo el control del Señor Supremo en Su forma de kala, el tiempo eterno. Hay un tiempo para la disolución del átomo [partícula última] y un tiempo para la disolución del universo" (Srimad Bhagavatam 3:10:10).

Conviene aclarar que generalmente es a Aristóteles a quien se atribuye, de manera errónea, la teoría del éter, probablemente debido a que él hace una definición prolija del mismo. Lo define como "cuerpo primario [la palabra elemento no es griega sino latina: elementum, primer principio], eterno, no sujeto a incremento o disminución, sin envejecimiento, inalterable e inmodificado"; sin embargo, enseguida apunta que:

"El nombre común [éter], el que nos ha sido legado por nuestros distantes ancestros, parece indicar que ellos lo concebian de la manera antes expresada [la dada en la definición]. Uno debe creer que las mismas ideas recurren en la mente humana, no sólo una o dos, sino múltiples veces. $Y$ así, implicando que el cuerpo primario es algo más allá de la tierra, el fuego, el aire y el agua, ellos dan al lugar más alto [la esfera de las estrellas] un nombre de suyo mismo, aither, derivado del hecho de que 'siempre corre' por toda la eternidad. Anaxágoras, sin embargo, escandalosamente hace mal uso de este nombre tomando al aither como equivalente al fuego." (De caelo [Acerca del cielo], libro 1, capítulo 3).

De lo anterior, se puede colegir que Aristóteles consideraba que el concepto de éter provenía de un tiempo antiguo (quizá derivado del Nun egipcio o del Maya hindú), sin dar crédito en lo absoluto a Anaximandro. En otra de sus obras, el Estagirita (Meteorología, libro 1, capítulo 3) vuelve a mencionar lo antiguo del concepto del éter y de la confusión de Anaxágoras sobre la naturaleza del mismo.

Al exponer su concepción acerca del origen de la vida, Anaximandro introduce una idea trascendental, la de la evolución de las especies, adelantándose en más de dos mil años a Lamarck y a Darwin. En su libro Sobre la naturaleza, Anaximandro consigna que los primeros organismos se originaron por generación espontánea en el lodo a partir de la humedad y de la bruma, gracias al calor del sol que evaporaba al agua, siendo similares a erizos de mar, los cuales se fueron modificando para adaptarse a los cambios del medio circundante. En esta hipótesis, Anaximandro hace intervenir tierra, agua, fuego y aire, adelantándose a Empédocles de Acragas (504-433 a.C.), considerado como quien propuso que se considerara a los cuatro elementos en conjunto, introduciendo la tierra junto al agua de Tales, el aire de Anaxímenes y el fuego de Heráclito. No obstante, es probable que la noción de los cuatro elementos, más el primordial éter, sea aún más antigua y se halla tomado de los que Aristóteles llamaba "distantes ancestros". Y estos últimos pudieron haberla tomado a su vez de culturas más antiguas, como la de los hindúes, ya que los cinco elementos vienen consignados explícitamente en la cosmogonía expuesta en el Srimad Bhagavatam (SB 3:26:12).

\subsection{El siglo XIX}

\subsubsection{Friedrich Wöhler (1800-1882)}

El químico alemán Wöhler, ya citado en la hipótesis de la ascendencia cósmica, de la línea 3, produjo la síntesis de la sustancia orgánica urea haciendo reaccionar ácido ciánico con hidróxido de amonio (Wöhler, 1828):

$$
\mathrm{HOCN}+\mathrm{NH}_{4} \mathrm{OH} \rightarrow \mathrm{CO}\left(\mathrm{NH}_{2}\right)_{2}+\mathrm{H}_{2} \mathrm{O}
$$

Este descubrimiento, aunque fortuito, ya que Wöhler esperaba obtener un compuesto de naturaleza inorgánica, fue de una importancia capital, puesto que demostró que existía continuidad entre la química orgánica y la inorgánica (división creada por el sueco Jöns J. Berzelius, partidario del vitalismo, quien, irónicamente, era maestro de Wöhler). No obstante, no fue sino hasta que A. W. H. Kolbe, en 1845, produjo ácido acético a partir de sus elementos químicos, que el vitalismo fue abandonado. 
9.2.2. Ernst Haeckel (1834-1919)

Aunque controvertido por los métodos que usaba, el zoólogo alemán Ernst Haeckel fue el primero en considerar el origen de la vida a partir de substancias inorgánicas. Habiendo sido influenciado profundamente durante su juventud por la lectura del "El origen de las especies..." de Charles Darwin, ha sido considerado como más darwinista que el mismo Darwin. Con base en el evolucionismo, elaboraba árboles filogenéticos para cualquier ser vivo, lo que lo llevó a examinar el problema representado por la base de tales árboles; es decir, el origen del primer organismo viviente.

Haeckel abordó el problema con base en el monismo materialista (o panteísta, como el mismo le llamaba), en el que la naturaleza es una sola, existiendo continuidad entre lo animado y lo inanimado. En esta filosofía todo es vida; toda la materia existente, desde los átomos, está dotada de vida, a manera del ápeiron de Anaximandro, a quien reconocía como el mejor de los filósofos griegos. Él pensaba que la vida había tenido su origen en organismos minúsculos, hechos de protoplasma simple, a los que llamó Monera. Consideraba, asimismo, que las propiedades fisicoquímicas del carbono (lo que fue llamado teoría del carbono) eran la única causa del protoplasma vivo, formado por un proceso de generación espontánea (Haeckel, 1866).

\subsubsection{Thomas Henry Huxley (1825-1895)}

Como uno de los pioneros de la teoría moderna sobre el origen químico de la vida debe reconocerse al biólogo T.H. Huxley, abuelo del célebre escritor Aldous L. Huxley. Aunque ferviente defensor de las ideas de Darwin, en tal concepto se adelantó a éste en su conferencia "Sobre las bases físicas de la vida", dictada en 1868, en Edinburgo, tres años antes de la famosa carta de Darwin a Hook. En 1869 publicó estas ideas en su libro Protoplasm, the physical basis of life. Él consideraba que el C, H, O y N, elementos que constituían la materia viva, así como los compuestos en que éstos existían, agua, ácido carbónico y compuestos de nitrógeno, no tenían vida, pero cuando estaban juntos, bajo determinadas condiciones, se combinaban para producir un cuerpo más complejo, el protoplasma, y éste exhibía el fenómeno de la vida. Decía, además, que él no veía discontinuidad alguna en las sucesivas etapas de complicación molecular progresiva.

\subsubsection{Charles Darwin (1809-1882)}

En cierta manera, el evolucionismo puede ser considerado dentro de la corriente del materialismo dialéctico, puesto que sostiene que las especies de seres vivos se han derivado de otras más simples, en oposición al creacionismo, según el cual las diversas especies fueron creadas cada una por separado tales como son ahora. Aunque el origen natural o "materialista" de la vida había sido considerado desde la antigüedad, como ya se mencionó, fue Darwin quien expuso de manera científica la hipótesis de la generación de materia viva a partir de la combinación de sustancias llamadas "orgánicas", aunque de origen inorgánico. Darwin, en el último párrafo de la edición de 1859 del "Origen de las especies..." anotó que la vida se había generado por un soplo de vida del Creador en uno o varios organismos; sin embargo, en 1871, en una carta al geógrafo Joseph Hooker, publicada en 1888, consignó la hipótesis antes mencionada en el párrafo siguiente, el que dada su trascendencia, se transcribe en su idioma original:

"It is often said that all the conditions for the first production of a living organism are now present, which could ever have been present. But if (and oh! what a big if!) we could conceive in some warm little pond, with all sorts of ammonia and phosphoric salts, lights, heat, electricity, etc. present, that a proteine (sic) compound was chemically formed ready to undergo still more complex changes, at the present day such matter would be instantly devoured or absorbed, which would not have been the case before living creatures were formed." (Darwin, 1871).

\subsection{Hipótesis de Oparin-Haldane}

El bioquímico ruso Aleksandr I. Oparin (1924) y el biólogo inglés John Haldane (1929), alentados por la identificación de compuestos orgánicos de estructura compleja en los meteoritos carbonosos y en los avances de la ciencia moderna, elaboraron hipótesis más fundamentadas que sus predecesores acerca de la teoría materialista del origen de la vida. Éstas tenían base en un "caldo primordial", así llamado por Haldane (1929), que coincidía con la "pequeña charca tibia" de Darwin, excepto en que ellos consideraban a la interfase atmósfera-océano como el entorno en que se originó la vida. Experimentos de laboratorio efectuados para probar las ideas de Oparin y Haldane han producido aminoácidos, que son considerados como los "ladrillos" de los que están construidas las proteínas, pero que no se pueden considerar como materia viva. Esta última se define como aquélla que tiene capacidad de metabolismo (que es cualquier reacción química dentro del protoplasma) y reproducción, además de crecimiento y reacción a los estímulos.

En 1922, en un congreso de la Sociedad Botánica Rusa, Oparin formuló una hipótesis similar a la de Darwin, pero sin conocer la carta de éste, aunque es probable que haya estado influido por él de manera indirecta a través de sus maestros, con quienes Darwin había estado en comunicación. Oparin (1924) cristalizó sus ideas en la primera edición de su ahora clásico libro "Origen de la vida". Esta obra fue publicada inicialmente como panfleto, pero adquirió forma de libro en la segunda edición, en 1936, de la que se hizo su traducción al inglés dos años más tarde (Oparin, 1938), y culminó con la tercera edición, en 1957, traducida al inglés ese mismo año (Oparin, 1957). Desde su aparición, este libro ha tenido una gran aceptación e influencia. Oparin llevó las teorías evolucionistas de Darwin, de manera independiente a él, como ya se había 
mencionado, al origen mismo de la vida a partir de compuestos inorgánicos. Según su hipótesis, el primer organismo surgió de un concentrado de compuestos orgánicos formado por coacervados (del latín coacervatus, cúmulo), que son grupos de gotas de coloides de dimensiones microscópicas formados por coalescencia de moléculas de proteínas y agua, promovido por enzimas que desempeñaron el papel de catalizadores del origen de la vida; los coacervados tienen la propiedad de duplicarse transmitiendo su estructura a los nuevos coacervados que pueden hacerse más complejos mediante la incorporación de nuevo material orgánico (Oparin, 2002). Así, los coacervados evolucionarían obedeciendo la regla darwiniana de supervivencia del más apto, al ser destruidas por el entorno hostil las estructuras más simples, mientras que las de estructura más avanzada lograrían subsistir y heredarían tal estructura a sus réplicas, que lograrían a su vez un nuevo avance. Las ideas de Oparin y la trascendencia de las mismas han sido expuestas con detalle por Lazcano (1995a, 1995b) y por Miller et al. (1997).

Pese a que Oparin (1957), con optimismo exagerado, vaticinó una próxima producción de materia viva en el laboratorio con base en su teoría, hasta la fecha esto no ha llegado a ocurrir. Por ello, se han presentado una serie de nuevas ideas, o han cobrado fuerza ideas antiguas, de las cuales las que han tenido una mayor aceptación son las hipótesis hidrotermal y extraterrestre.

\subsubsection{Experimento de Urey-Miller}

La hipótesis de Oparin fue apoyada por el experimento clásico de Stanley L. Miller y Harold C. Urey (Miller, 1953), quienes a partir de una mezcla de amoníaco, metano, hidrógeno y vapor de agua, que se suponía en esa época que eran los constituyentes de la atmósfera primigenia, la que se sometía periódicamente a descargas eléctricas que generaban chispas, produjeron aminoácidos y otras sustancias orgánicas denominadas "melanoides". Experimentación ulterior de estos investigadores expandió el rango de los productos orgánicos sintetizados (Miller y Urey, 1959; Miller, 1998).

\subsection{Hipótesis hidrotermal del origen de la vida}

\subsubsection{Fundamentos del hidrotermalismo}

Definición. Hidrotermalismo es el conjunto de efectos producidos por el agua con temperatura considerablemente mayor que la ambiental, llamada "agua hidrotermal", que asciende de zonas profundas del subsuelo. Esta agua puede ser meteórica, calentada en el subsuelo, o magmática, que se libera junto con otros volátiles de un magma que asciende, debido a la disminución en la presión y temperatura en dicho magma. Al agua magmática también se le llama "agua juvenil" por considerarse que es la primera vez que sale a la superficie.

Naturaleza de los fluidos hidrotermales. Cuando el magma inicia su camino ascendente desde la cima del manto superior o desde la base de la corteza, gracias a alguna fisura, al disminuir la presión y la temperatura tiene lugar el proceso llamado diferenciación magmática, que consiste en la cristalización de minerales en una serie progresiva conforme disminuye la temperatura. Este proceso hace que se formen diversos tipos de roca a partir del magma parental, separándose finalmente las fracciones más ligeras, más alcalinas y más acuosas en la parte superior de las cámaras magmáticas. Estas son las aguas magmáticas o juveniles, que transportan los elementos de mayor movilidad, los que aunque presentes en cantidades muy pequeñas, son comunes en todos los magmas: $\mathrm{Cu}, \mathrm{Pb}, \mathrm{Zn}, \mathrm{Ag}, \mathrm{Au}, \mathrm{Li}, \mathrm{Be}, \mathrm{B}, \mathrm{Rb}$, $\mathrm{Cs}, \mathrm{Na}, \mathrm{K}$ y Ca. La capacidad de transporte de metales se incrementa en gran medida con la presencia de $\mathrm{H}_{2} \mathrm{~S}, \mathrm{Cl}^{-}, \mathrm{F}^{-}$ y otros volátiles, que forman complejos con los metales.

La composición de los fluidos depende principalmente de cuatro factores: (1) tipo de magma parental y su historia de cristalización, (2) condiciones de presión y temperatura, (3) mezcla con aguas de otras fuentes, y (4) asimilación de la roca encajonante.

En el caso de las condiciones que debieron prevalecer en la época en la que se originó la vida, se puede decir que la primera corteza fue de composición basáltica, compuesta principalmente por los primeros minerales en cristalizar, según la serie de reacción de Bowen: olivino, piroxeno y plagioclasa cálcica. Es probable que los intersticios de esta primera corteza hayan sido ocupados por minúsculas gotas de un líquido residual. Este líquido pudo ser de dos naturalezas dependiendo del predominio de azufre o de oxígeno (combinado en minerales, nunca libre) en una zona determinada: de sulfuros o de óxidos. El líquido de sulfuros contiene principalmente los metales $\mathrm{Fe}, \mathrm{Cu}, \mathrm{Ni}, \mathrm{Zn}$ y a los elementos del grupo de platino. Por su parte, el líquido de óxidos contiene principalmente $\mathrm{Cr}, \mathrm{Fe}, \mathrm{Ti}$, V y P; cuando hay una alta concentración de $\mathrm{Na}$, puede producirse el "efecto álcali", en el que se separa una fase inmiscible rica en $\mathrm{Fe}$ y $\mathrm{PO}_{4}$ (Guilbert y Park, 1986). El fluido residual puede aún contener un líquido de silicatos, con $\mathrm{Fe}, \mathrm{Mg}, \mathrm{Al}, \mathrm{Ca}$, $\mathrm{Na}$ y K, que puede formar diques o derrames de lava de composición más silícica.

\subsubsection{Distribución del hidrotermalismo}

La presencia de hidrotermalismo depende de que haya ascenso del magma, ya sea que este salga a la superficie o quede emplazado en cámaras magmáticas dentro de la corteza, que funcionan como fuentes de calor de los sistemas hidrotermales, ya que el agua desempeña la función de transportar el calor hacia el fondo marino o hacia la superficie. En la actualidad, la actividad hidrotermal se concentra principalmente en el océano Pacífico, y es debida a la interacción de las placas tectónicas. Esta interacción puede ser de tipo distensivo, en el que las placas se alejan una de otra (Figura 11); convergente, en el que una placa se desliza por debajo de la otra, en el fenómeno conocido como subducción; o transformante, con desplazamiento a rumbo 


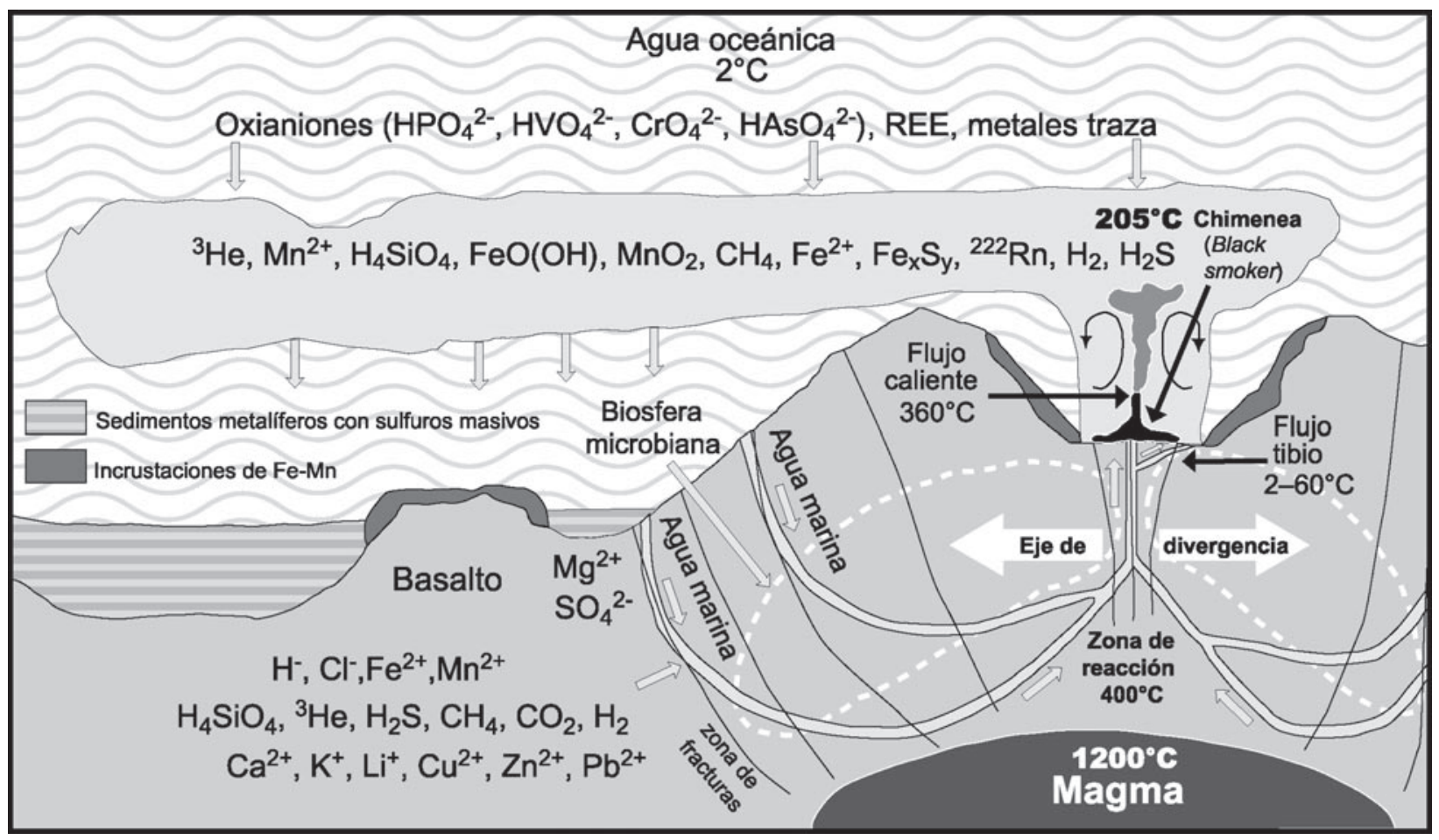

Figura 11. Diagrama esquemático de un sistema hidrotermal submarino en una dorsal océanica en el que se muestran las distintas temperaturas que se tienen en las diferentes partes que constituyen el sistema hidrotermal. Una gran diversidad de componentes es producida por una celda convectiva de agua que al calentarse lixivia las rocas de la corteza oceánica, cuya permeabilidad se incrementa con las fracturas, y al enfriarse súbitamente al salir al fondo del mar deposita dichos componentes. La convección es generada por la energía calorífica irradiada por el magma que asciende en el eje de la dorsal. Modificado de Butterfield (2002).

entre ellas. Se ha estimado que los sistemas hidrotermales del sistema global de dorsales oceánicas (Figura 12), que comprende $46,000 \mathrm{~km}$, tienen un área de influencia que alcanza la tercera parte del piso oceánico, lo que da una idea de su importancia, no bien conocida actualmente. Se ha llegado a proponer, incluso, que su influjo se extiende a los fenómenos climáticos mundiales, como el de El Niño.

\subsubsection{Desarrollo histórico de la teoría del hidrotermalismo}

Aunque los manantiales termales que depositaban minerales deben haber sido notados desde los albores de la humanidad, no fue sino hasta la Grecia clásica que se hicieron los primeras referencias conocidas acerca del origen de los depósitos minerales. Hoover y Hoover (1912 [1950]) anotan que Aristóteles consignó que la transmutación de los elementos (tierra, agua, aire y fuego) en el subsuelo producía "exhalaciones" de dos tipos: una ardiente, que producía las rocas, y otra húmeda, que producía los metales. Los mismos autores señalan que Teofrasto, discípulo del Estagirita, en su obra "Acerca de las rocas" reproducía la opinión de su maestro como sigue: "De las cosas formadas en la Tierra, algunas tienen su origen en el agua, otras en la tierra. El agua es la base de los metales, plata, oro y el resto; la tierra, de las rocas.... Todas ellas se forman por solidificación de materia pura y son iguales en sus partes constituyentes [lo que parecería una anticipación a la "ley de las proporciones constantes" de Dalton] la que ha sido traída a ese estado por mera afluencia o por medio de algún tipo de percolación....". Infortunadamente, se perdió un segundo libro de Teofrasto, Acerca de los metales. Además, Hoover y Hoover (1912 [1950]) hacen ver que el simple nombre de "vena", con el que los latinos (entre ellos, Plinio) denominaban a las vetas, es digno de reflexión; y en efecto, en él está implícito el concepto de "circulación". También, de la semántica se hace patente que en la antigüedad ya se intuían conceptos estructurales, puesto que, según Plinio, citado por Hoover y Hoover (1912 [1950], p. 42), los griegos derivaron "metalla" del hecho de que dondequiera que hubiese una veta de plata, otra se encontraría de seguro en sus cercanías. Barcia, en su Diccionario Enciclopédico, consigna que en griego "metal" se decía $\mu \varepsilon \tau \alpha \lambda \lambda$ ov (metallon), derivado de metallan, buscar, palabra formada por $\mu \varepsilon \tau \alpha$ (metá): más allá, y $\alpha \lambda \lambda \circ \varsigma$ (allós), otro, aludiendo a que, generalmente, las vetas se suceden unas a otras en las minas.

La influencia de la escuela peripatética se mantuvo hasta el inicio del siglo XVI, cuando apareció publicado el folleto Ein Nützlich Bergbüchlein (Un opúsculo práctico sobre yacimientos), publicado al parecer en 1505, sin nombre de autor, pero atribuido por Agrícola a Kalbus, nombre latinizado, según la usanza de la época, de Ulrich Rühlein 


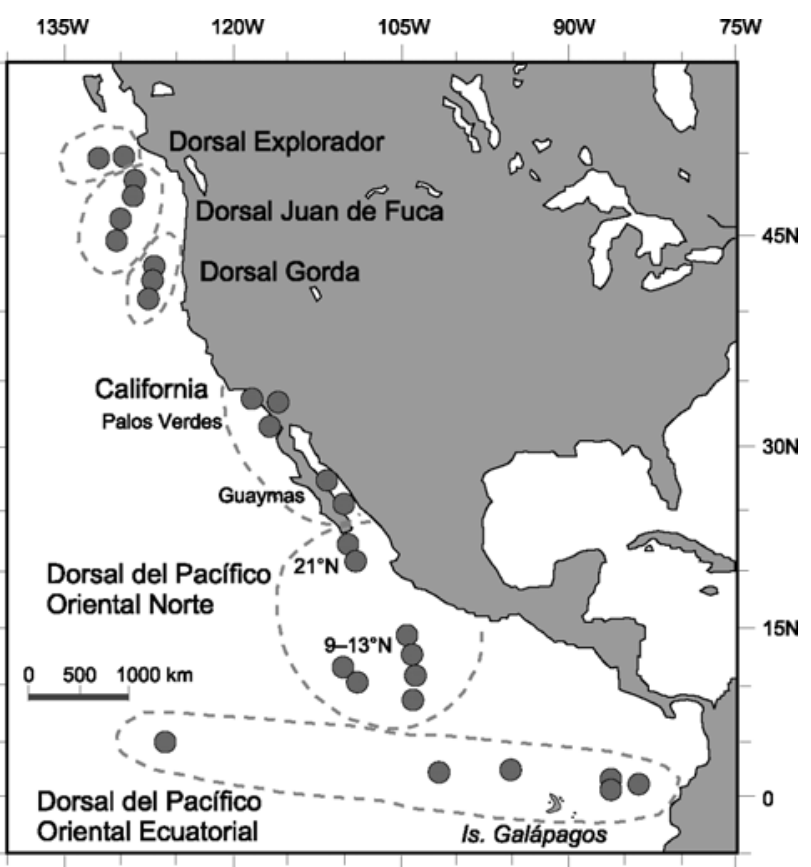

Figura 12. Sistema de dorsales del Pacífico oriental en el hemisferio norte. Se muestran los sitios con actividad hidrotermal, los cuales están relacionados con centros de expansión. Compilado por Mark Hannington. (http://triton.ori.u-tokyo.ac.jp/ intridge/images/nepacific.gif)

von Kalbe y que constituye la primera publicación impresa sobre depósitos minerales. Si bien en ese pequeño tratado se mantenía la idea de las emanaciones aristotélicas, se agregaba la participación del azufre en la formación de los minerales de mena. Daubrée hizo la traducción al francés de este folleto (disponible en Internet). Esta pequeña obra tuvo una gran influencia, tanto por sus conceptos, su organización de los temas y el estilo de sus grabados, en Georgius Agrícola, quien escribió varios libros, siendo los principales Bermannus, en 1530; De natura eorum quae effluuntex terra (De las sustancias que fluyen de la tierra), De orto et causis subterraneorum (Del origen y causas de lo subterráneo) y De natura fossilium (De los minerales), las tres en 1546; y De re metallica (De las cosas metálicas), en 1556. En ellos, el médico alemán dejaba claramente establecido que las vetas de minerales eran fisuras de origen posterior al de las rocas encajonantes en las que los minerales se depositaban a partir de soluciones formadas por agua meteórica que circulaban por ellas. Estos conceptos refutaban categóricamente la concepción aristotélica de la formación de las vetas a partir de "emanaciones" acuosas, noción sostenida por von Kalbe. A Agrícola se deben varios postulados fundamentales que, al menos parcialmente, se mantienen en la actualidad: (1) Que las vetas se formaban posteriormente a las rocas encajonantes (epigénesis); en la Edad Media prevalecía el concepto bíblico de la creación simultánea de todo el reino mineral, siendo él el primero en rechazar enfáticamente tal creencia manifestando que era una opinión vulgar. (2) Que el agua era de origen meteórico en vez de magmático, como se infería de las "emanaciones" peripatéticas. (3) Que la fuente de los metales eran las rocas encajonantes. (4) Que el agua circulaba por convección, descendiendo a grandes profundidades donde se calentaba, lixiviaba los metales de las rocas por las que pasaba y ascendía por los "canales", mezclándose con el agua fría superficial, en los que depositaba dichos metales.

En la segunda mitad del siglo XVIII, tuvo lugar una de las controversias científicas más célebres que hayan existido: la del escocés James Hutton con el alemán Abraham Gottlob Werner. Hutton, a quien se considera como el padre de la geología, sostenía la hipótesis llamada "plutonismo", según la cual tanto las rocas ígneas como los depósitos minerales se formaban debido a magmas que ascendían y se solidificaban. En contraste, Werner propugnaba la doctrina del "neptunismo", que consideraba que tanto las rocas, incluyendo las ígneas, como los depósitos minerales se depositaban como sedimentos clásticos o por precipitación química en un océano primigenio. Esta disputa se asemeja a la de Agrícola (agua meteórica) contra las ideas de Aristóteles (agua magmática), y es reminiscente de la diferencia de opinión, antes vista, entre los filósofos griegos Tales, que sostenía que el agua era el principio de todo, y Heráclito, que decía que lo era el fuego. Si bien, en cuanto a las rocas ígneas se refiere, Hutton tenía la razón, en lo que toca a los depósitos minerales hidrotermales, era Werner, profesor en la reputada Academia de Minería de Freiberg, quien estaba en lo correcto, aunque él sólo consideraba aguas descendentes.

En el inicio del siglo XIX, si bien el origen de las vetas a partir del agua obtuvo una aceptación general, al quedar plenamente establecida la noción de que las rocas ígneas provenían del magma, el neptunismo cayó en descrédito. Debido a ello, se asumió que los fluidos mineralizantes provenían del magma (a pesar de la hipótesis de Agrícola), del cual se separaba por diferenciación magmática. Esta corriente de opinión fue encabezada por Beaumont (1847), quien publicó un artículo que tuvo influencia por más de un siglo, en el que asentaba que los depósitos minerales se formaban tanto por segregación magmática como por "emanaciones acuosas" de origen ígneo. Ahora, el que disentía de tal origen era Daubrée (1887) —que en 1841 fundara la mineralogía experimental, al obtener casiterita artificial a partir de cloruro estannoso-, quien consideraba que los fluidos mineralizantes consistían en aguas subterráneas de origen meteórico que descendían hasta calentarse, disolvían parte de las rocas por las que pasaban, y ascendían precipitando los minerales de las vetas, coincidiendo en todo con Agrícola. A pesar de ello, la opinión general era de que los depósitos minerales se formaban a grandes profundidades, donde no llegaba el agua meteórica ( $c f$. Bateman, 1950).

En la época contemporánea fue White (1955) el primero en señalar que algunos depósitos epitermales estaban claramente relacionados a manantiales calientes probablemente dominados por agua meteórica. Más tarde, 
el mismo White (1974) estableció los tipos genéticos de agua siguientes: (1) meteórica; (2) oceánica; (3) connata (atrapada en los poros de los sedimentos); (4) metamórfica; (5) magmática (sin considerar su origen inicial); (6) juvenil (que surge a la superficie por primera vez).

La mineralización en el fondo del mar por manantiales termales fue postulada desde hace casi un siglo para explicar los depósitos de hierro bandeados (que constituyen alrededor del 90\% de las reservas mundiales) y de manganeso estratificado (Van Hise y Leith, 1911). Esa hipótesis se hizo extensiva a los depósitos de sulfuros masivos (Oftedahl, 1958), lo que fue comprobado al descubrirse que en el mar Rojo se están depositando sedimentos metalíferos, que incluyen calcopirita, esfalerita y galena, precipitados a partir de fluidos de alta salinidad (Miller, 1964). No obstante, antes de este último descubrimiento ya había sido observado, por primera vez en forma directa, el depósito de minerales metálicos a partir de fluidos hidrotermales, cuando en 1962, durante la perforación de un pozo de la naciente industria geotérmica, se cortó a $1,500 \mathrm{~m}$ de profundidad una estructura que contenía una salmuera a $350{ }^{\circ} \mathrm{C}$ de temperatura, que al salir a la superficie depositó sedimentos con $20 \% \mathrm{Cu}$ y $8 \% \mathrm{Ag}$. En 1977, en la dorsal de las Galápagos, a una profundidad de $\sim 2,500 \mathrm{~m}$, el submarino de investigación Alvin descubrió los manantiales termales submarinos (Weiss et al., 1977) que, sorprendentemente, estaban rodeados de colonias de animales entonces desconocidos, por lo que el sitio recibió después el nombre de Jardín de Rosas, sujetos a una elevada presión y en oscuridad absoluta. Entre ellos, se destacaban enormes gusanos de tubo (clasificados luego como Riftia pachyptila), algunos de los cuales alcanzaban los $3 \mathrm{~m}$ de altura, junto con almejas y mejillones de hasta $25 \mathrm{~cm}$. Estas colonias subsistían gracias a bacterias que oxidaban el azufre del $\mathrm{H}_{2} \mathrm{~S}$ contenido en los fluidos emanados, con lo que podían transformar el $\mathrm{CO}_{2}$, presente tanto en los fluidos hidrotermales como en el agua marina, en formaldehído $\left(\mathrm{CH}_{2} \mathrm{O}\right)$, que les servía de alimento, fenómeno conocido como quimiosíntesis, de acuerdo con la siguiente reacción:

$$
2 \mathrm{H}_{2} \mathrm{~S}+\mathrm{CO}_{2} \rightarrow \mathrm{CH}_{2} \mathrm{O}+2 \mathrm{~S}+\mathrm{H}_{2} \mathrm{O}
$$

Por análisis isotópico se ha determinado que el origen del azufre es principalmente magmático, desprendido en los gases volcánicos, y que sólo el $15 \%$ corresponde a azufre derivado de la reducción de los sulfatos disueltos en el agua marina. En 1979, el Alvin pudo observar in situ el fenómeno de mineralización metálica al descubrir en la dorsal Rivera, segmento del sistema de dorsales del Pacífico oriental, en la latitud $21^{\circ} \mathrm{N}$ y a $\sim 2,500 \mathrm{~m}$ de profundidad, frente a las costas de Nayarit, una serie de solfataras, de color oscuro por la precipitación de sulfuros, emitidas a través de orificios en chimeneas de sulfuros metálicos ( $\mathrm{Fe}, \mathrm{Zn}, \mathrm{Cu})$ que alcanzaban los dos metros de altura (Speiss et al., 1980) (Figura 13). Inesperadamente, los fluidos emanados eran de muy alta temperatura, ya que mientras que en la dorsal de Galápagos el agua era apenas tibia $\left(<25^{\circ} \mathrm{C}\right)$, aquí alcanzaba los $400{ }^{\circ} \mathrm{C}$. Estos manantiales son ahora llamados "black smokers" debido a que el piloto del Alvin, Dudley Foster, notó su similitud con las locomotoras de vapor, a las que suele llamarse smokers en inglés. Se observó que alrededor de las chimeneas existía un manto de sulfuros polimetálicos, equivalente moderno de los sulfuros masivos vulcanogénicos fósiles. Subsecuentemente se hizo el hallazgo de solfataras en la bahía de Guaymas y de toda una serie de manantiales submarinos a lo largo del sistema global de dorsales. Con anterioridad a estas investigaciones se consideraba que todos los sulfuros masivos eran formados por acción hidrotermal posterior al depósito de las rocas sedimentarias, por un proceso de reemplazo. Por lo que toca a la síntesis de moléculas orgánicas en el ambiente hidrotermal, Ferris (1992) presentó una revisión de los estudios al respecto.

\subsubsection{Oparin y Bresler, precursores de la hipótesis hidrotermal}

Como alternativa a la teoría de Oparin, aunque fundada en ella, la hipótesis del origen hidrotermal de la vida introduce un número mayor de factores, acercándose más a la complejidad real de la naturaleza y creando nuevas expectativas a explorar para la resolución de este problema crucial. No obstante, la hipótesis hidrotermal, en realidad, no es más que una afinación, resultante de los avances en la investigación científica, de la teoría de Oparin quien, incluso, mencionó la obtención de la síntesis de compuestos orgánicos complejos (polipéptidos), a partir de aminoácidos y "otros productos de la desintegración proteínica", bajo presiones de varios miles de atmósferas, realizada por $\mathrm{S}$. Bresler en Leningrado, condiciones que "pueden producirse fácilmente en condiciones naturales en la Tierra, como sucede en las grandes profundidades de los océanos" (Oparin, 2002, p. 56). Aunque la razón de usar alta presión fue que bajo esas condiciones la síntesis de compuestos orgánicos requiere de una menor cantidad de energía suministrada, se puede considerar a Bresler como el pionero en los estudios experimentales de la hipótesis hidrotermal y a Oparin como uno de los primeros exponentes de esta hipótesis. La diferencia fundamental entre la época de Oparin y la actual radica en la fuente de energía: para Oparin, lo fue la radiación ultravioleta del sol, en una atmósfera que aún no contaba con la cubierta protectora de ozono, así como las descargas eléctricas durante las tormentas, mientras que en la actualidad lo es la energía geotérmica, presente en los manantiales termales submarinos, descubiertos hasta 1977.

\subsubsection{John B. Corliss, pionero de la hipótesis hidrotermal}

John B. Corliss, oceanógrafo de Oregon State University, planeó y dirigió la expedición de 1977 del submarino Alvin, la cual llevó al sorpresivo descubrimiento de los manantiales submarinos de las islas Galápagos y de 


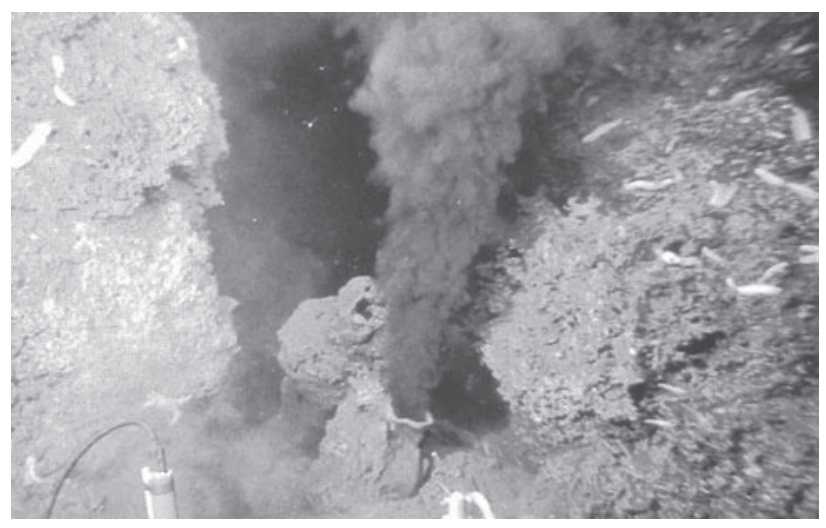

Figura 13. Fotografía de la primera solfatara submarina (black smoker), descubierta en 1979 en la dorsal Rivera a $21^{\circ} \mathrm{N}$, que emitía fluidos hidrotermales a una temperatura cercana a $400^{\circ} \mathrm{C}$. Su color oscuro se debe a la precipitación de sulfuros de $\mathrm{Fe}, \mathrm{Zn}$ y $\mathrm{Cu}$ (pirita, esfalerita y calcopirita) al entrar en contacto dichos fluidos con el agua marina de temperatura alrededor de $2^{\circ} \mathrm{C}$. Fotografía tomada por el submarino Alvin, de la Woods Hole Oceanographic Institution; crédito de la fotografía: W.R. Normark, del U.S. Geological Survey.

sus complejos sistemas de vida asociados en lo que hasta entonces se consideraba que era un lugar frío, en oscuridad total y desolado (Weiss, 1977; Corliss et al., 1979). Poco después, él expuso la hipótesis hidrotermal del origen de la vida (Corliss et al., 1980, 1981) y su grupo de trabajo insistió posteriormente en ella (Baross y Hoffman, 1985). El papel que desempeña la presión fue considerado por Nickerson (1984).

Corliss y su equipo mantuvieron la noción de Oparin, de que los primeros organismos abrían sido heterótrofos, es decir, incapaces de elaborar su propia materia orgánica, la que habrían tomado del medio circundante.

\subsubsection{Sintesis experimental de Wächtershäuser}

La hipótesis hidrotermal del origen de la vida de Corliss empezó a cobrar importancia cuando el químico alemán Günter Wächtershäuser, planteó la hipótesis de que los primeros organismos serían de tipo termofílico y, a diferencia de lo expuesto por Oparin y Corliss, quimioautótrofos. Tales organismos habrían estado dotados de un metabolismo efectuado en la superficie de partículas sólidas de sulfuros de metales de transición, principalmente sulfuros de hierro (Wächtershäuser, 1988a, 1988b). Las superficies de los minerales contribuirían a proteger a los compuestos orgánicos de la hidrólisis. Las chimeneas, que son los pilares que se forman sobre las ventilas hidrotermales, están formadas, en su mayoría, por sulfuros de hierro. Dependiendo de la concentración del $\mathrm{H}_{2} \mathrm{~S}$, los más abundantes de éstos son la pirrotita $\left(\mathrm{Fe}_{1-\mathrm{x}} \mathrm{S}\right)$ y la pirita $\left(\mathrm{FeS}_{2}\right)$. La pirrotita reacciona con el $\mathrm{H}_{2} \mathrm{~S}$, cambiando su sistema de cristalización, para transformarse en pirita, con lo que se produce energía libre así como electrones, lo que favorece los procesos metabólicos. Los iones metálicos en los sulfuros desempeñarían el papel de catalizadores, ya que en condiciones prebióticas no existían las enzimas (catalizadores orgánicos) (Wächtershäuser, 1988a). Huber y Wächtershäuser (1997) reportaron que, añadiendo selenio como catalizador a las superficies de NiS-FeS, obtuvieron ácido acético $\left(\mathrm{CH}_{3}-\mathrm{CO} \cdot \mathrm{OH}\right)$ y metil mercaptano $\left(\mathrm{CH}_{3}-\mathrm{SH}\right)$, reacción a la que consideran como iniciadora del origen quimioautotrófico de la vida.

Un grupo del Carnegie Institution of Washington, adoptando la línea de Wächtershäuser, está realizando trabajo experimental aprovechando la infraestructura de esa institución en investigación petrológica de alta presión y temperatura. Dicho grupo utilizó sulfuros de níquel y cobalto, en cuyas superficies obtuvieron la síntesis de moléculas de cadena larga mediante la inserción de átomos de carbono por el proceso de "carbonilación" (adición del radical carbonilo: $=\mathrm{C}=\mathrm{O}$ ). Los radicales carbonilo se unen inicialmente a los iones de $\mathrm{Ni}$ y Co en las superficies de sulfuros, pero de ahí, por mayor afinidad, se liberan para insertarse dentro de las cadenas orgánicas (Hazen, 2001).

Posteriormente, Huber y Wächtershäuser (1998) emprendieron la experimentación con compuestos propios de las chimeneas hidrotermales. Ellos produjeron reacciones en cadena que culminaron con la síntesis de péptidos que se formaron sobre superficies de $(\mathrm{Fe}, \mathrm{Ni}) \mathrm{S}$ a partir de aminoácidos, usando como catalizadores $\mathrm{CO}, \mathrm{H}_{2} \mathrm{~S} \mathrm{o} \mathrm{CH}_{3} \mathrm{SH}$, a $100^{\circ} \mathrm{C}$ y pH de $7-10$. Este logro tiene una gran importancia porque los péptidos son compuestos similares a proteínas; sin embargo, como se mencionó antes, Oparin consignó que Bresler ya los había obtenido.

\subsubsection{Hipótesis de Russell}

En la Universidad de Glasgow existe un grupo de investigación encabezado por el inglés Michael Russell, quien está aplicando su experiencia en yacimientos minerales a la hipótesis hidrotermal del origen de la vida. El objetivo de ese proyecto es encontrar una explicación sobre cómo pudo haberse originado el organismo vivo más simple, intentando comprobar en un sistema hidrotermal real las etapas de síntesis de sustancias orgánicas que postularon previamente en varias publicaciones (por ejemplo, Russell et al., 1988; Russell y Hall, 1997, 2002; Martin y Russell, 2003).

La hipótesis de Russell postula que la vida surgió en los manantiales termales submarinos, que contenían $\mathrm{H}_{2} \mathrm{~S}$ y Fe lixiviado por los fluidos calientes de la primitiva corteza basáltica, rica en este metal. En el fondo oceánico, estas sustancias reaccionaban entre sí para precipitar FeS en cristales microscópicos, que constituyen las chimeneas o montículos que se forman sobre las ventilas hidrotermales en el piso oceánico. Como una de las condiciones esenciales para las primeras células era contar con membranas que aislaran el protoplasma, Russell postula que los poros o cavidades dentro de la espuma de sulfuros de hierro que forma las chimeneas, desempeñaron inicialmente el papel de armazón que favoreció el desarrollo de las membranas verdaderas (Figura 14). Este precipitado poroso de sulfuros 
de hierro sirvió como filtro que retuvo las moléculas orgánicas sintetizadas a gran profundidad gracias a las altas temperaturas de las rocas magmáticas en enfriamiento. La alta concentración de material orgánico favorecería la organización de moléculas cada vez más complejas, hasta alcanzar la frontera con la materia viva: el ácido ribonucleico (RNA).

En favor de la teoría de Russell puede decirse que en los montículos de sulfuros podría operar el mecanismo de difusión iónica, es decir, la migración de iones hacia las celdillas de los montículos en ausencia de flujo, además del proceso original de infiltración, para enriquecer el concentrado orgánico con otros compuestos, debido a que las soluciones hidrotermales experimentan una evolución constante en sus características fisicoquímicas $(\mathrm{P}, \mathrm{T}, \mathrm{pH}$, Eh) que se manifiesta en el transporte de compuestos diferentes en cada etapa. La concentración de los compuestos inorgánicos encontrados en los organismos es más efectiva en los sistemas hidrotermales que incluyen fósforo, elemento que se ha demostrado que forma, al estar en contacto con azúcares y ciertos hidróxidos, cadenas cortas de ácidos nucleicos que tienen la capacidad de formar réplicas de sí mismos, característica esencial de la materia viva.

\subsubsection{Experimento de Imai}

El potencial de los sistemas hidrotermales como generadores de vida fue probado experimentalmente por investigadores de la Universidad de Tokio (Imai et al., 1999), quienes construyeron un modelo de un sistema hidrotermal submarino que eyectaba agua a unos $350^{\circ} \mathrm{C}$ por una ventila, a $200 \mathrm{~atm}$ de presión, equivalente a una profundidad de 2,000 $\mathrm{m}$ bajo el nivel del mar, con lo que se trataba de emular las condiciones naturales (Figura 15). Al fluido hidrotermal se le agregó glicina $\left(\mathrm{NH}_{2}-\mathrm{CH}_{2}-\mathrm{CO} \cdot \mathrm{OH}\right)$, el más simple de los aminoácidos, y se obtuvo como resultado oligopéptidos, que son cadenas con una cantidad reducida de aminoácidos. Al agregarse cobre al fluido hidrotermal, que es un elemento común en los sistemas hidrotermales asociados al vulcanismo submarino, se obtuvo oligopéptidos de cadena más larga; de esto se infiere que los elementos metálicos usualmente involucrados en el hidrotermalismo, podrían actuar como catalizadores en la síntesis orgánica.

\subsection{Debate acerca de la hipótesis hidrotermal}

Siendo el origen de la vida el problema más importante de la investigación científica, no es de extrañar que en torno a él se haya suscitado una encendida polémica. El experimento de Miller (1953) inició la investigación moderna acerca del origen de la vida, pero en su contra se ha argumentado que la atmósfera primitiva consistía en una mezcla, un tanto inerte, de $\mathrm{CO}_{2}, \mathrm{~N}_{2}$ y $\mathrm{H}_{2} \mathrm{O}$, con sólo trazas de $\mathrm{H}_{2}$ (Huber y Wächtershäuser, 1997).
La hipótesis hidrotermal (Corliss et al., 1980, 1981; Baross y Hoffman, 1985), que parecería ser una consecuencia inmediata del descubrimiento de los manantiales termales submarinos (Corliss et al., 1979), fue considerada en ese entonces como completamente infundada por Nisbet (1986) y Miller y Bada (1988).

Nisbet (1986), en una combinación de la hipótesis de la charca tibia de Darwin con la hipótesis hidrotermal de Corliss, propuso que el lugar más favorable para el origen de la vida sería efectivamente un ambiente hidrotermal, pero terrestre. En un ambiente hidrotermal somero se concentrarían, más fácilmente que en el océano, metano, amoníaco y fosfatos, a un $\mathrm{pH}$ de $\sim 8$ y una temperatura de unos $40^{\circ} \mathrm{C}$. El hidrotermalismo produciría zeolitas, arcillas y sulfuros de metales pesados que proveerían las superficies catalíticas, el tamiz molecular en el cual el RNA sería ensamblado y los poros en los que estaría contenido.

Miller y Bada (1988) y Bada et al. (1995) argumentaron que la alta temperatura en las ventilas hidrotermales tendería a destruir antes que a sintetizar los compuestos orgánicos. A esto Wächtershäuser respondió que en ambos ambientes marinos, el superficial y el de las ventilas hidrotermales, la proporción en la que se crean y se destruyen dichos compuestos es la misma, pero que esto tiene lugar con mayor frecuencia en las últimas, lo que equivale a "arrojar los dados con mayor frecuencia”. Por otra parte, no se debe pasar por alto que en las ventilas existe un gradiente de temperatura, desde $1,200^{\circ} \mathrm{C}$ en el magma, hasta $2^{\circ} \mathrm{C}$ en el agua marina (Figura 11); por ejemplo, en las Galápagos, la temperatura era de alrededor de $25^{\circ} \mathrm{C}$.

Si bien el experimento de Urey-Miller demostró que es posible la producción natural de aminoácidos en los océanos, Michael Russell adujo en contra que tales compuestos serían dispersados. En contraste, las chimeneas hidrotermales permitirían la concentración de los aminoácidos. Respecto a la factibilidad de la hipótesis de la charca tibia, que implica un ambiente continental, Russell hace notar que en el Hadeano no existían aún los continentes y que, dado que la Luna estaba más cercana que ahora, las mareas eran muy intensas y que además el intenso bombardeo de meteoritos provocaba tsunamis, lo que representaba un ambiente sumamente hostil para la creación de la vida. En contraste, en el fondo oceánico, las condiciones favorables para la vida podían extenderse hasta profundidades considerables, siempre y cuando la temperatura no sobrepasara los $110^{\circ} \mathrm{C}$ (Russell en Simmons, $\mathrm{s} / \mathrm{f})$.

El límite superior de temperatura citado arriba se ha visto incrementado actualmente, lo que ha aumentado, a su vez, la profundidad de la biosfera, en cuyos límites se ha identificado una nueva familia de organismos quimiosintéticos litoautótrofos, que no requiere de sustancias orgánicas para su alimentación. Pyrolobus fumarii, un organismo hipertermofílico que representa un grupo nuevo de Archaea, fue hallado en una chimenea hidrotermal del sitio TAG, en la Dorsal del Atlántico Medio, 


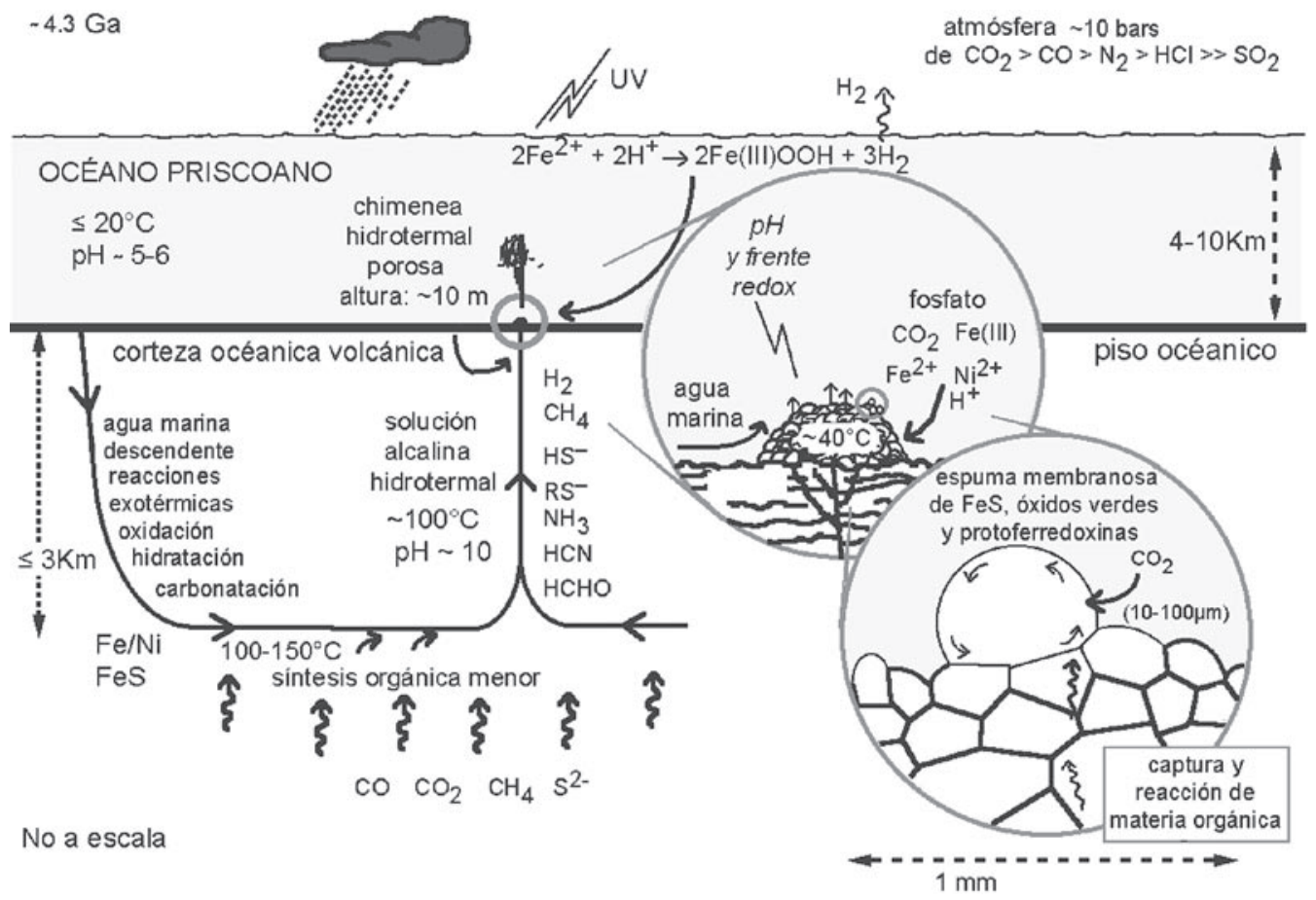

Figura 14. Diagrama esquemático en el que se muestra la hipótesis de Russell y colaboradores sobre el origen de la vida, que consiste en la presencia de una celda de circulación de agua por convección dentro del sustrato océanico. El agua marina fría desciende hasta llegar a una fuente magmática de calor donde se calienta, con lo que adquiere el poder de lixiviar las rocas del piso oceánico llevando en solución a la superficie del mismo los componentes que precipitan como sulfuros metálicos en cuyos poros se aglutinan ulteriormente componentes orgánicos, en condiciones favorables para su evolución hasta la formación de los primeros organismos (Modificado de Russell et al., 2001).

a 3,650 $\mathrm{m}$ de profundidad. Este organismo se reprodujo en condiciones de 90 a $113^{\circ} \mathrm{C}, 250$ bars y $\mathrm{pH}$ de 4.0 a 6.5 (Blochl et al., 1997). Tal límite de temperatura se elevó aún más con el descubrimiento reciente de un microorganismo aún no clasificado, también perteneciente a Archaea, que fue llamado Strain 121 debido a que resistió una prueba de esterilización en una autoclave a $121^{\circ} \mathrm{C}$. Este microbio se halló en una muestra recolectada por John Baross en una ventila del segmento Endeavour de la dorsal Juan de Fuca (Figura 12) a unos 2,500 m de profundidad, a la cual el agua hierve a más de $400^{\circ} \mathrm{C}$. El Strain 121 posee un mecanismo de respiración antes desconocido, en el que el hierro desempeña el papel del oxígeno. El ion férrico acepta un electrón para reducirse al ion ferroso con lo que se forma el mineral magnetita, mecanismo que es considerado como la primera forma de respiración microbiana en una Tierra primitiva y caliente (Kashefi y Lovley, 2003).

Recientemente, el importante papel del sulfuro de hierro en el origen de la materia viva, postulado por Wächtershäuser (1988a, 1988b) se ha visto apoyado por Rees y Howard (2003). Ellos consideran que la frontera entre la materia inanimada y la animada la constituyen complejos de azufre y hierro con otros metales como molibdeno, níquel y cobre, ya que, en las enzimas de la materia viva moderna, estos complejos catalizan las reacciones redox que transforman $\mathrm{N}_{2}, \mathrm{CO}$ y $\mathrm{H}_{2}$ en compuestos orgánicos. La pirrotita (FeS con cierta deficiencia en $\mathrm{Fe}$ ), uno de los minerales más abundantes en los sulfuros masivos vulcanogénicos, sería capaz de proporcionar los elementos químicos necesarios para la formación de tales complejos, ya que normalmente contiene trazas de $\mathrm{Mo}$, Ni y $\mathrm{Cu}$.

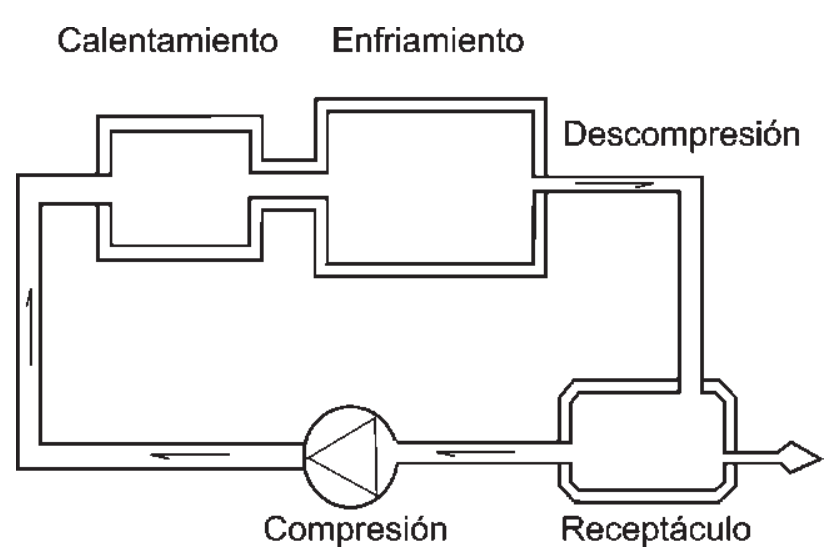

Figura 15. Diagrama que muestra el experimento de Imai y colaboradores en el que se simuló un sistema hidrotermal submarino, en condiciones de acidez, en el que fueron obtenidos oligopéptidos a partir de aminoácidos simples, como la glicina, con la presencia de cobre como catalizador (Tomado de Imai et al., 1999). 


\subsection{Hipótesis de la arcilla sobre el origen de la vida}

El papel de las arcillas en el origen de la vida ha sido considerado desde la antigüedad, por ejemplo por Anaximandro, como ya se dijo; incluso, ha sido llevado al extremo por algunos, quienes han llegado a considerar, quizá por influencia del génesis bíblico, que los primeros organismos estuvieron hechos completamente de arcilla. Dado que la concentración de la llamada "materia orgánica" en los primeros océanos debió haber sido muy baja, dificultando el proceso de coalescencia de la misma, científicos como Haldane, Bernal, Cairns-Smith y Ferris asumieron que las arcillas y otros minerales pudieran haber desempeñado el papel de concentradores en virtud de su capacidad de adsorción y de su peculiar estructura en láminas paralelas que habría funcionado como armazón para que los materiales orgánicos simples se convirtieran en polímeros. Dado que el origen de la vida por accidente ha sido criticado por Fred Hoyle, mediante cálculos de probabilidad, un mecanismo factible de formación de RNA es la conversión de monómeros a oligómeros por adsorción selectiva de los monómeros hecha por montmorillonita (Ferris y Erten, 1993).

\subsubsection{Arcillas}

Dentro de las arcillas, el grupo de la esmectita, también llamado de la montmorillonita, tiene un comportamiento extraordinario. Las arcillas de este grupo consisten en láminas (por lo que se les llama filosilicatos) que a manera de sandwich están formadas por dos capas de tetraedros constituidos por $\mathrm{Si}$ en los centros y átomos de $\mathrm{O}$ en los vértices, y una capa, en medio de las anteriores, formada por octaedros de $\mathrm{Al}$ en los centros y $\mathrm{O}$ en los vértices; en ambas superficies de cada capa se hallan cationes que son fácilmente intercambiables. Una característica típica de este grupo es que entre dos capas de arcilla se halla una de agua, lo que le da una gran capacidad de aumentar su volumen.

\subsubsection{Zeolitas}

Las zeolitas forman un grupo extenso de minerales que tiene como característica principal su capacidad reversible de ceder agua de su estructura cristalina al calentarse sin perder su estructura molecular y de ahí su nombre (del griego, piedra que hierve). Otras de sus características son la capacidad de intercambio catiónico selectivo, dependiendo del mineral, y la presencia de oquedades de tamaño uniforme dentro de su estructura, lo que les permite funcionar como filtros moleculares; por tanto, es frecuente que contengan en forma natural compuestos de amoníaco e hidrocarburos. Las zeolitas se forman por reacción entre aguas alcalinas con ceniza y vidrio volcánicos, como en las lagunas de aguas salobres en zonas volcánicas áridas; de interés para el tema aquí tratado es que también son comunes como minerales de alteración de los depósitos de sulfuros masivos vulcanogénicos. La estructura de las zeolitas consiste en tetraedros de $\mathrm{Si}$, parcialmente reemplazado por
$\mathrm{Al}$, en una relación particular para cada mineral del grupo, dejando una valencia negativa libre que atrae a los cationes, principalmente de metales alcalinos y alcalinotérreos, los cuales se unen entre sí por medio de átomos de oxígeno situados en los vértices, dejando grandes huecos cuyo tamaño varía de 2 a $10 \AA$, según la estructura de que se trate, que se intercomunican por canales más pequeños. En estos huecos se alojan moléculas de agua así como una gran diversidad de adsorbatos. Se emplea como catalizador en la industria petroquímica aprovechando que su estructura microporosa ejerce una selectividad geométrica fijada por el tamaño de sus oquedades. Actualmente, se conoce un total de 48 especies minerales de zeolitas naturales, y de 150 sintéticas, mientras que el número de estructuras naturales es de 40 con 100 sintéticas (Figura 16). Además de las cavidades de la estructura molecular, existen los huecos irregulares dejados por los cristales al acomodarse unos sobre otros (Figura 17). En virtud de estas características, las zeolitas, sobre todo algunas de ellas como la clinoptilolita, resultan un campo fértil para la colonización por bacterias. Por esta propiedad, se ha propuesto que las zeolitas, en vez de las arcillas, hayan servido como armazón para la formación de las primeras células.

\subsection{Hipótesis de la serpentinización}

En la dorsal del Atlántico, Islandia se destaca por su hidrotermalismo, principalmente en forma de géysers; no obstante, en este océano se descubrió, en diciembre de 2000, una fuente de energía diferente al magmatismo: la producida por la reacción del agua marina con el basalto, proceso llamado "serpentinización". Este fenómeno, que ha despertado un gran interés, ha sido postulado como hipótesis alterna sobre el origen de la vida. En el monte submarino denominado "macizo Atlantis", situado en la mitad del océano Atlántico, al oriente de la costa este de Estados Unidos, se descubrió un campo de unas 30 ventilas hidrotermales en un área de 500 x $100 \mathrm{~m}$, en el que se halla la chimenea más grande hasta ahora encontrada, de unos $50 \mathrm{~m}$ de altura, pero que no está hecha de sulfuros sino de carbonatos. Esta chimenea, llamada "la Ciudad Perdida" no está sobre la dorsal, sino sobre corteza oceánica de 1.5 $\mathrm{Ma}$, por lo que el hidrotermalismo aquí no es generado por vulcanismo reciente. La chimenea alberga una colonia de microorganismos que sobreviven gracias a la producción de $\mathrm{CH}_{4}$ y $\mathrm{H}_{2}$ formados durante el proceso de serpentinización. El intervalo de temperatura registrado fue de 40 a $77^{\circ} \mathrm{C}$.

\subsection{En busca del precursor de la vida}

En la actualidad no se conoce qué tipo de compuesto pudo haber dado origen al primer organismo vivo. Todas las formas de vida conocidas se basan en el ácido 
A

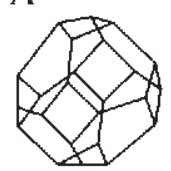

Cristal

Individual
B

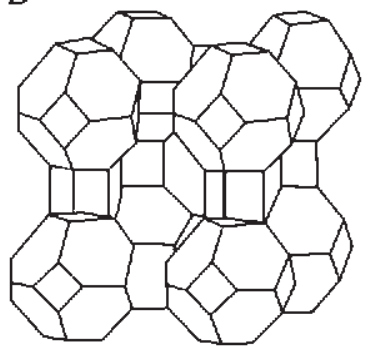

Esinuctura LTA

Diŕunctro de poro: $4.1 \mathrm{~A}$

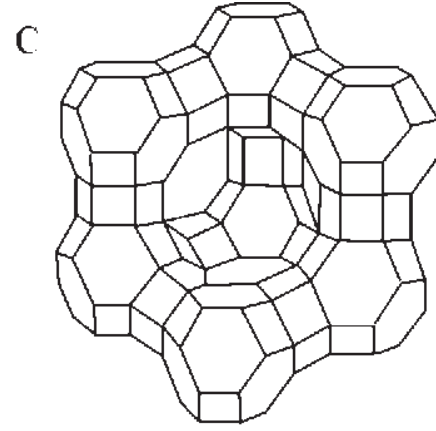

Falujasitat

Diámetro de poro: $7.4 \mathrm{~A}$

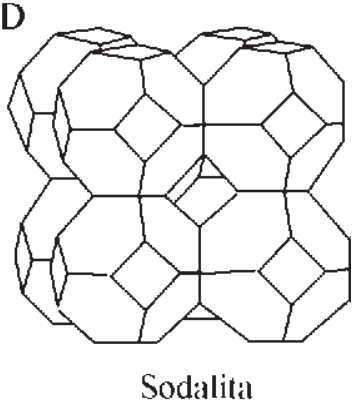

Sodialita

Figura 16. Diagramas estructurales de las zeolitas. Las estructuras consisten en arreglos geométricos particulares de los cristales individuales de cada mineral. Se presentan las estructuras en el modo simplificado, que consiste en líneas que unen los centros de los tetraedros; es decir, cada vértice representa un catión de $\mathrm{Si}$ o de $\mathrm{Al}$, omitiéndose los oxígenos ligados a los cationes. $(A)$ Cristal individual. (B) Estructura LTA $($ Linde Type A). $(C)$ Estructura de la faujasita y de los tipos sintéticos X y Y. $(D)$ Con fines de comparación, se muestra la estructura de la sodalita, un feldespatoide, con una cavidad más pequeña.

desoxirribonucleico (DNA) y en enzimas proteínicas. Sin embargo, durante un tiempo, el RNA fue considerado teóricamente como esencial para el presunto surgimiento de la vida en el "caldo primigenio", sin importar el ámbito en el que haya sido formada. Altman (1984), bioquímico de Yale, y Cech (1986), de la Universidad de Colorado, en experimentos independientes, descubrieron las ribozimas, que son moléculas de RNA que pueden desempeñar la doble función de DNA (almacenar los códigos genéticos) por un lado, y de proteína o enzima (catalizar las reacciones bioquímicas; es decir, efectuar el metabolismo), por el otro; esto les valió el premio Nobel de Química de 1989. Antes de este descubrimiento, se tenía el dilema del "huevo y la gallina": el metabolismo dependía de enzimas, que son proteínas, pero las proteínas requieren de la información genética codificada en el DNA y traducida a RNA; es decir, para su formación las proteínas requieren de ácidos nucleicos y los ácidos nucleicos no pueden ser hechos sin proteínas. El descubrimiento de las ribozimas condujo al establecimiento de la hipótesis del "mundo RNA", término acuñado por Gilbert (1986), biólogo molecular de Harvard y también galardonado con el Nobel. No obstante, se tenían las limitaciones de la falta de citosina y uracil, dos bases químicas que se encuentran sólo en el RNA.

Stanley L. Miller, quien iniciara la experimentación abiótica sobre el origen de la vida en la Universidad de Chicago como estudiante graduado del laureado con el premio Nobel Harold C. Urey, en 1953, ahora en la Universidad de California en San Diego, hizo reaccionar cianoacetaldehido (que podría haber sido creado por la acción de rayos en la Tierra primitiva) y una solución de urea concentrada mediante calor, obteniendo citosina, de la que por simple hidrólisis puede formarse uracil. Para explicar la presencia de urea concentrada, Miller planteó que tales hechos pudieron tener lugar en lagunas o en playas marinas en las que la evaporación ocasionó la concentración requerida, y no en el océano abierto. Sin embargo, este tipo de ambiente fue descalificado por Russell, como ya se dijo, pero Miller argumentó que la radiación ultravioleta pudo ser bloqueada por capas de hielo o de polímeros orgánicos formados por la acción de las descargas eléctricas. No puede dejar de mencionarse que dentro del grupo de investigación de Miller se encuentra el destacado científico mexicano, Antonio Lazcano.

En 1994 se obtuvo por primera vez la síntesis de DNA enzimático. Esto fue logrado en el Instituto de Investigación Scripps por R.R. Breaker. Desde entonces, varias enzimas tanto de DNA como de RNA han sido sintetizadas por diferentes laboratorios, pero un paso muy importante fue anunciado por investigadores de la Universidad de Bochum (Luther et al., 1998), en Alemania, quienes reportan la obtención de moléculas de DNA que no sólo son capaces de copiarse a sí mismas, sino que también son capaces de evolucionar. En dicho estudio se presupone que las moléculas proliferaron extendiéndose sobre superficies minerales. Este es un paso de gran importancia en el estudio del origen de la vida, aunque la tendencia actual es a considerar que los organismos primitivos no tenían DNA, sino sólo RNA o aun un precursor más sencillo.

En la hipótesis del "mundo RNA", se asume que las moléculas de RNA se formaron espontáneamente a partir de los monómeros producidos por síntesis prebiótica y que tenían la capacidad de catalizar su propia réplica. Sin embargo, Rebek (1994) creó una molécula simple que se copiaba a sí misma: el éster triácido de aminoadenosina. Joyce (2002) estima que es factible que la fuente de material genético haya sido todavía más primitiva que el RNA, habiendo existido un "mundo pre-RNA", constituido por polímeros con propiedades especiales, haría unos $4 \mathrm{Ga}$. Esto, debido a que los "ladrillos" formadores de RNA (ribosa, fosfatos, purina $y$, en particular, pirimidina) hubieran sido difíciles de seleccionar entre una cantidad 


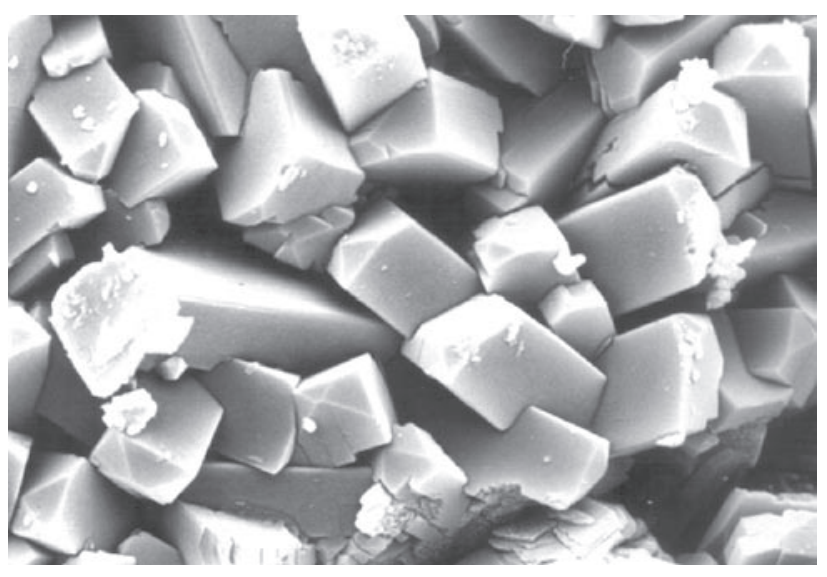

Figura 17. Imagen de la superficie de una zeolita (clinoptilolita) que muestra cristales de unos $5 \mu \mathrm{m}$ de espesor cuyo acomodo al azar deja huecos que permiten la fácil colonización por bacterias (Fuente: Internet, Dryden Aqua).

mucho mayor de nucleótidos análogos, por lo que el RNA "debió haber sido precedido por otro tipo molecular más sencillo, estable y fácil de sintetizar" (Antonio Lazcano, comunicación escrita, 4 de octubre de 2003).

\subsection{Hidrotermalismo y panspermia}

Se ha determinado la existencia de agua bajo la superficie de algunos cuerpos planetarios del sistema solar, o de sus lunas, como Europa, la luna de Júpiter cubierta de hielo. En ella, se ha postulado la presencia de manantiales termales bajo la capa de hielo, que pudieran sustentar organismos vivientes, por similitud con la Tierra, lo que está siendo contemplado por la NASA para su investigación. Ahora bien, la relación entre la hipótesis hidrotermal y la panspermia es tal que Christopher F. Chyba, del Search for Extraterrestrial Intelligence Institute, ha expresado que la hipótesis hidrotermal abre la posibilidad de la presencia de vida en otras partes del sistema solar, ya que son más los lugares con evidencias de geotermalismo que con iluminación solar adecuada, y que, en cierto modo, la comprobación de la teoría hidrotermal estará en Europa.

Recientemente, se ha hallado agua en meteoritos. El primer descubrimiento de agua líquida en un meteorito se efectuó en el que cayó en el pueblo de Monahans, Texas, el 22 de marzo de 1998. Este meteorito fue clasificado como una brecha de regolita (regolita es la capa de roca fragmentada y sin consolidar que cubre a la roca firme), con fragmentos claros y oscuros cementados por una matriz gris. Al examinar el material en el Centro Espacial Johnson de la NASA, se descubrió en la matriz gris la existencia de cristales de halita $(\mathrm{NaCl})$, hasta de $3 \mathrm{~mm}$ de diámetro, de color púrpura brillante por la radiación en el espacio, que contenían inclusiones fluidas, constituidas por agua, comprobada mediante análisis, con una burbuja de gas
(Figura 18), lo que revela que el cristal en el que se alojan las inclusiones se formó a partir de material del que se separó una fase de agua, similar a los fluidos hidrotermales terrestres. El asteroide del que se deriva este meteorito se supone que consistía en material rocoso que contenía agua calentada por efecto de la desintegración radiactiva de isótopos de corta vida media, de los que había una gran abundancia en los inicios del sistema solar, como el ${ }^{26} \mathrm{Al}$. Debido a que sólo unas cuantas de las inclusiones fluidas muestran burbujas, se estima una temperatura de formación inferior a $100^{\circ} \mathrm{C}$, asumiendo una presión baja. Asimismo, la abundancia de inclusiones fluidas secundarias, generalmente debidas a fracturas después de haberse formado el cristal, señala que el sistema hidrotermal siguió activo después de haberse depositado la evaporita (Zolensky et al., 1999).

Sorprendentemente, en el mes de agosto del mismo año se anunció por parte del mismo centro espacial el hallazgo, en el llamado meteorito Zag (Figura 19), caído en Marruecos, también de cristales de halita púrpura con inclusiones fluidas con agua, por lo que se supone que ambos meteoritos sean fragmentos del mismo asteroide parental. La datación de los cristales de halita, con base en el isótopo ${ }^{129} \mathrm{I}$, que decae a ${ }^{129} \mathrm{Xe}$, dio $4.57 \mathrm{Ga}$, una de las edades más antiguas obtenidas, lo que indica que existió por lo menos un corto período con agua en los inicios del sistema solar (Whitby et al., 2000).

El análisis de la relación deuterio/hidrógeno en un meteorito caído en el Sahara en diciembre de 2000, de los denominados nakhlitas, que se considera que provienen de

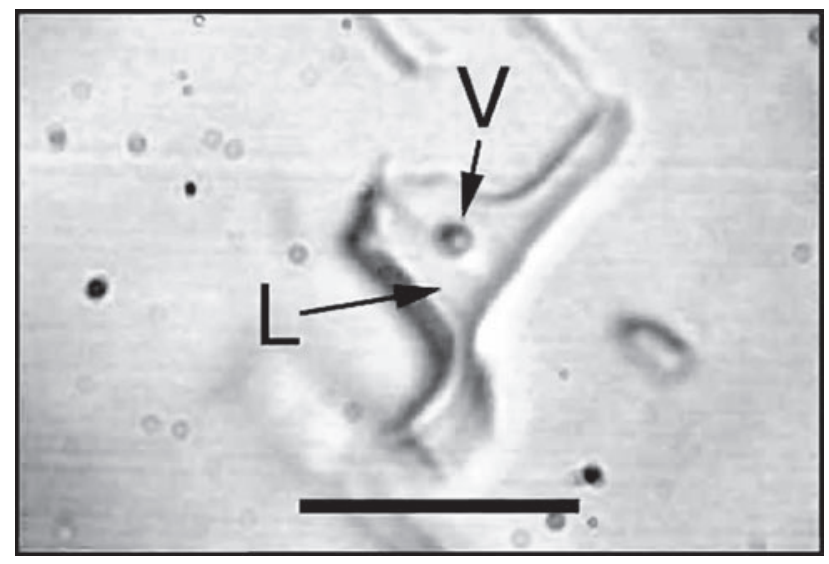

Figura 18. Fotomicrografía de una inclusión fluida en cristales de halita $(\mathrm{NaCl})$ en el meteorito caído en Monahans, Texas, que representa el primer hallazgo de agua líquida extraterrestre, analizada por microsonda Raman, sin presencia de volátiles, como $\mathrm{CO}_{2}, \mathrm{~N}_{2} \mathrm{y} \mathrm{CH}_{4}$. La inclusión fluida consiste en una irregularidad microscópica del cristal de halita en la que quedó atrapada una minúscula porción del mismo fluido que presumiblemente dio origen al cristal. La burbuja está formada por vapor separado del líquido, lo que denota que la temperatura a la que fue atrapada la porción de fluido fue mayor que la temperatura ambiente a la que fue tomada la fotomicrografía, lo que es indicativo de hidrotermalismo. Longitud de la barra: $5 \mu \mathrm{m}$. L, líquido; V, vapor (Tomado de Zolensky et al., 1999). 
Marte, mostró una relación baja, por lo que se cree que este meteorito haya estado en contacto con agua que provino del interior de Marte en vez de agua superficial.

La presencia de hidrotermalismo en los asteroides queda demostrada por el meteorito del Lago Tagish, al que se clasifica como de tipo 2 , que se caracterizan por la presencia de minerales hidratados de baja temperatura que reemplazan a minerales de alta temperatura, reteniendo la textura de estos últimos.

\section{Conclusiones}

Desde Beaumont (1847), el hidrotermalismo es considerado como la etapa final de un ciclo magmático, que generalmente incluye actividad volcánica. El vulcanismo es el medio por el cual la Tierra transfiere calor de su interior a su superficie. Bien puede decirse que un sistema hidrotermal representa las condiciones de la Tierra en la época en que se originó la vida, puesto que los componentes de los fluidos hidrotermales dieron origen a la atmósfera, primero, y a los océanos, después, como ya se mencionó.

La presencia de compuestos orgánicos complejos en meteoritos y el análisis fisicoquímico en cuerpos espaciales ha venido a confirmar la idea propuesta por Oparin acerca de la síntesis de compuestos orgánicos por procesos inorgánicos debida a la capacidad intrínseca del carbono para formar tales compuestos orgánicos. Es más, la aparición del carbono, que es la base de las moléculas orgánicas, poco después del origen del universo parecería indicar que existe una liga indisoluble entre universo y vida, lo que algunos han llegado a llamar "universo viviente".

La panspermia, o hipótesis extraterrestre, está cobrando impulso debido a los problemas que enfrentan tanto la hipótesis de Oparin-Haldane como la hidrotermal, y a descubrimientos recientes, como el de la presencia de moléculas orgánicas complejas en cierto tipo de estrellas. Esto último se ha explicado por la síntesis de materia orgánica a partir de los gases y el polvo estelar en el espacio, activados por la radiación emitida por esas estrellas. Esta idea tiene en su favor el que las reacciones químicas en el espacio han operado durante más tiempo que las reacciones en la Tierra. El aporte a la Tierra de material extraterrestre no sólo consiste en los meteoritos; quizá de mayor importancia sea la cantidad de polvo cósmico, estimada en unas 40,000 toneladas anuales, que incesante y lentamente ha caído en toda la superficie del planeta, desde sus inicios, sin sufrir los efectos de la fricción. También en favor de la panspermia, está el hecho de que la vida parecería haber existido en la Tierra desde los mismos inicios de ésta como planeta, como lo demuestra la presencia, con un grado alto de certidumbre, de formas de vida ya complejas en las primeras rocas sedimentarias descubiertas, las de los cinturones de roca verde de Groenlandia y Canadá. Al corto tiempo transcurrido antes de que la vida apareciera en la
Tierra, se agrega que la probabilidad calculada para el origen accidental de un ser vivo es muy remota, por lo que se está prestando una gran atención al origen extraterrestre.

La teoría hidrotermal introduce una mayor complejidad que la que se tiene en el ambiente de la teoría de OparinHaldane. A causa de tal complejidad, en los sistemas hidrotermales podrían conjuntarse los fenómenos conjeturados por otras teorías, como el del efecto de las arcillas. La parte superior de la corteza oceánica está formada por rocas volcánicas en cuya composición predominan los feldespatos. El agua caliente y rica en volátiles de los sistemas hidrotermales altera de diferentes maneras a estos feldespatos, dando origen a minerales hidratados llamados de alteración hidrotermal. Entre ellos destaca la presencia de zeolitas y de arcillas que pueden ser de diversas composiciones y cuyas propiedades químicas excepcionales bien pudieron coadyuvar tanto en el inicio de la vida, como en su preservación ulterior al limpiar, por adsorción, las aguas marinas de elementos de alta toxicidad, tales como el cobre.

Otro factor en apoyo de la teoría hidrotermal lo constituye la estructura cristalina de los minerales, que es la característica principal de éstos. Esta propiedad parece, por ahora, ser la única capaz de efectuar la imprescindible separación de los compuestos orgánicos en levógiros y dextrógiros, en un medio abiótico. Mientras que el experimento de Miller produce aminoácidos de ambos tipos en aproximadamente la misma relación, la materia viva muestra un marcado predominio de las moléculas levógiras sobre las dextrógiras. Experimentos sobre la adherencia de

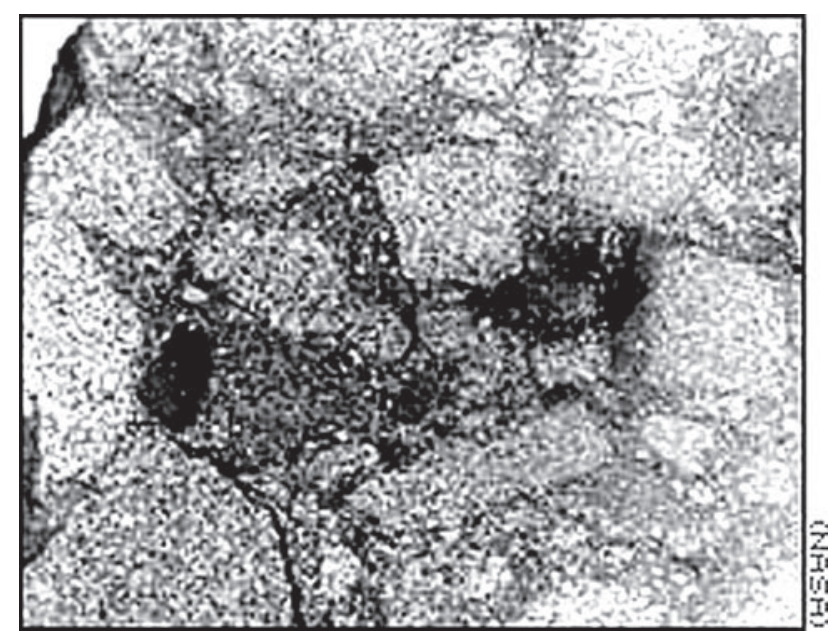

Figura 19. Fotografía del meteorito Zag, caído en Marruecos en agosto de 1998, que contiene cristales de halita púrpura, por radiación cósmica, datada en $4.57 \mathrm{Ga}$ y que contiene inclusiones fluidas con agua. El material es una brecha constituida por fragmentos angulares cementados por una matriz de grano fino. Este meteorito, junto con el Monahans, ambos presumiblemente provenientes del mismo asteroide, es la prueba de que en los inicios mismos del sistema solar existieron sistemas hidrotermales con agua calentada por la desintegración radiactiva de elementos de corta vida media. 
moléculas orgánicas en cristales de calcita hechos por Hazen (2001) mostraron que en las caras cristalinas positivas predominaba un tipo sobre el otro, mientras que en las caras negativas simétricas a las anteriores sucedía lo contrario. De lo anterior resulta que en un ambiente abundante en minerales, como lo es el hidrotermal, los compuestos levógiros, una vez separados, sobrevivirían por selección darwiniana mientras que los dextrógiros desaparecerían.

También en favor de la hipótesis hidrotermal, está el pH de las aguas. En experimentos de laboratorio realizados para producir compuestos orgánicos se obtuvieron azúcares, como glucosa y fructosa, en condiciones alcalinas, a partir de formaldehido en presencia de catalizadores; tales azúcares son necesarios para la formación de sustancias más complejas. Mientras que el agua de los primeros océanos era ligeramente ácida debido a una concentración elevada de $\mathrm{CO}_{2}$ en ellas, el $\mathrm{pH}$ en los sistemas hidrotermales es casi neutro con ligeras oscilaciones hacia lo ácido y lo alcalino (pH de 6 a 8), con Eh bajo (-0.1 mV), es decir, con un potencial de oxidación-reducción ligeramente reductor, lo que es fundamental para la permanencia de la vida.

El presunto ambiente reductor de la atmósfera primigenia, requerido para la generación de la primera materia viva en la interfase océano-atmósfera y que fuera supuesto por Oparin, ha sido puesto en duda con base en la producción de oxígeno por disociación química de moléculas de agua debida a la radiación solar (fotólisis), fenómeno que debió haberse presentado desde el inicio de la formación de la atmósfera por exhalaciones magmáticas, en las que predomina el vapor de agua. No obstante, como quedara establecido por Stanley Miller, quien propuso este mecanismo, el oxígeno formaría una capa de ozono que favorecería la vida en la interfase citada. Por su parte, los fluidos hidrotermales de origen magmático no contienen oxígeno libre y pueden tener una concentración alta en $\mathrm{H}_{2} \mathrm{~S}$, constituyendo el ambiente reductor apropiado para la formación de la vida.

La salinidad es otro factor en pro de la hipótesis hidrotermal, ya que los fluidos hidrotermales muestran un rango de salinidad muy amplio, que va desde agua prácticamente dulce hasta agua saturada en $\mathrm{NaCl}$. Un estudio mostró que los iones $\mathrm{Na}^{+}, \mathrm{Cl}^{-}, \mathrm{Mg}^{2+}, \mathrm{Ca}^{2+}$ y $\mathrm{Fe}^{2+}$, aun en concentraciones bajas, afectan adversamente tanto la formación de membranas celulares como la polimerización del RNA (Monnard et al., 2002).

Aunque actualmente existe una gran controversia al respecto, en el caso de que se llegara a demostrar la existencia de vida en Marte, esto no haría sino trasladar el problema del origen de la vida a ese planeta. Sea la materia orgánica del meteorito ALH84001 de origen biótico o abiótico, es evidente que se formó en un sistema hidrotermal debido a que se encuentra en las paredes de fracturas mineralizadas y a que la asociación mineral, sideritamagnetita-pirrotita, es común en los sistemas hidrotermales terrestres, en los que puede o no haber actividad biológica.

El concepto de que la vida se originó a partir de materia inerte, es decir, el de la generación espontánea aunque en condiciones primigenias en la Tierra o, bien, en el espacio, se ha convertido en uno de los postulados que sirven de cimiento a la ciencia moderna, pero debe dejarse sentado que ésta, hasta ahora, no ha podido demostrar experimentalmente el "salto dialéctico" de Oparin, mediante el cual compuestos orgánicos con un alto nivel de organización y con la capacidad de duplicarse, se conviertan en seres vivos, y que el grado de complejidad de las sustancias orgánicas obtenido en el laboratorio al presente resulta ínfimo en comparación con la complejidad del organismo más sencillo.

\section{Agradecimientos}

Se reconoce ampliamente la acuciosa revisión crítica y las atinadas sugerencias de los dos árbitros, el Dr. Antonio Lazcano Araujo, Presidente de la International Society for the Study of the Origin of Life, y el Dr. Héctor Durand Manterola, quienes contribuyeron a mejorar sustancialmente el manuscrito original.

\section{Referencias bibliográficas}

Altman, S., 1984, Aspects of biochemical catalysis: Cell, 36, 237-239.

Bada, J.L., Miller, S.L., Zhao, M., 1995, The stability of amino acids at submarine hydrothermal vent temperatures: Origins of Life and Evolution of the Biosphere, 25, 111-118.

Baross, J.A., Hoffman, S.E., 1985, Submarine hydrothermal vents and associated gradient environments as sites for the origin and evolution of life: Origins of Life and Evolution of the Biosphere, 15, 327345 .

Bateman, A.M., 1950, Economic Mineral Deposits: Nueva York, John Wiley, $2^{\mathrm{a}}$ ed., $916 \mathrm{p}$.

Beaumont, É. de, 1847, Note sur les émanations volcaniques et métallifères: http://gallica.bnf.fr/Fonds_Frantext/T0088272.htm).

Bernal, J.D., 1961, Significance of carbonaceous meteorites in theories on the origin of life: Nature, 190, 129-131.

Blochl, E., Rachel, R., Burggraf, S., Hafenbradl, D., Jannasch, H.W., Stetter, K.O., 1997, Pyrolobus fumarii, gen. and sp. nov., represents a novel group of Archaea, extending the upper temperature limit for life to 113 degrees C: Extremophiles, 1, 14-21.

Bowring, S.A., Williams, I.S., 1999, Priscoan (4.00-4.03) orthogneisses from northwestern Canada: Contributions to Mineralogy and Petrology, 134, 3-16.

Brandes, J.A., Boctor, N.Z., Cody, G.D., Cooper, B.A., Hazen, R.M., Yoder, H.S., 1998, Abiotic nitrogen reduction on the early Earth: Nature, 395, 365-367.

Brown, P.G., Hildebrand, A.R., Zolensky, M.E., Grady, M., Clayton, R.N., Mayeda, T.K., Tagliaferri, E., Spalding, R., MacRae, N.D., Hoffman, E.L., Mittlefehldt, D.W., Wacker, J.F., Bird, J.A., Campbell, M.D., Carpenter, R., Gingerich, H., Glatiotis, M., Greiner, E., Mazur, M.J., McCausland, P.J.A., Plotkin, H., Mazur, T.R., 2000, The fall, recovery, orbit, and composition of the Tagish Lake meteorite- $\mathrm{a}$ new type of carbonaceous chondrite: Science, 290, 320-325.

Butterfield, D.A., 2002, Context of hydrothermal venting in the chemical balance of the Earth: http://oceanexplorer.noaa.gov/explorations/ 02fire/background/vent_chem/ventchem.html.

Caldwell, R.R., Kamionkowski, M., Weiberg, N.N., 2003, Phantom energy and cosmic doomsday: http://arxiv.org/abs/astro-ph/0302506.

Cech, T.R., 1986, A model for the RNA-catalyzed replication of RNA: 
Proceedings of the National Academic of Sciences, 83, 4360-4363.

Cernicharo, J., Heras, A.M., Tielens, A.G.G.M., Pardo, J.R., Herpin, F., Guélin, M., Waters, L.B.F.M., 2001, Infrared Space Observatory's discovery of $\mathrm{C}_{4} \mathrm{H}_{2}, \mathrm{C}_{6} \mathrm{H}_{2}$, and benzene in CRL 618: Astrophysical Journal, 546, L123.

Chen, J.H., Wasserburg, G.J., 1981, The isotopic composition of uranium and lead in Allende inclusions and meteoritic phosphates: Earth and Planetary Science Letters, 52, 1-15.

Cooper, G., Kimish, N., Belisle, W., Sarinana, J., Brabham, K., Garrel, L., 2001, Carbonaceous meteorites as a source of sugar-related organic compounds for the early Earth: Nature, 414, 879-883.

Corliss, J.B., Dymond, J., Gordon, L.I., Edmont, J.M., von Herzen, R.P., Ballard, R.D., Green, K., Williams, D., Bainbridge, A., Crane, K., van Andel, T.H., 1979, Submarine thermal springs on the Galápagos Rift: Science, 203, 1073-1083.

Corliss, J.B., Baross, J.A., Hoffman, S.E., 1980, Submarine hydrothermal systems - a probable site for the origin of life: Corvallis, Oregon State University, School of Oceanography, Special Publication 807.

Corliss, J.B., Baross, J.A., Hoffman, S.E., 1981, An hypothesis concerning the relationship between submarine hot springs and the origin of life on Earth: Oceanologia Acta, 4, 59-69.

Darwin, C.R., 1871 (1888), Letter to Joseph Hooker, in Darwin, F. (ed.), The Life and Letters of Charles Darwin: Londres, John Murray, 3, p. 18.

Daubrée, G.A., 1887, Les eaux souterraines aux epoques anciennes: París, $445 \mathrm{p}$.

Ehrenfreund, P., Glaxin, D.P., Botta, O., Cooper, G., Bada, J.L., 2001, Extraterrestrial amino acids in Orgueil and Ivuna - tracing the parent body of CI type carbonaceous chondrites: Proceedings of the National Academy of Sciences, 98(5), 2138-2141.

Encyclopedia of Astrobiology, Astronomy, and Spaceflight: http:// www.angelfire.com/on2/daviddarling/ETEmain.htm.

Farley, J., 1977, The Spontaneous Generation Controversy-from Descartes to Oparin: Baltimore, John Hopkins University Press, $225 \mathrm{p}$.

Fedo, C.M., Whitehouse, M.J., 2002a, Metasomatic origin of quartzpyroxene rock, Akilia, Greenland, and implications for Earth's earliest life: Science, v. 296, p. 1448-1452.

Fedo, C.M., Whitehouse, M.J., 2002b, Origin and significance of Archean quartzose rocks at Akilia, Greenland-response: Science, 298, p. 917.

Ferris, J.P., 1992, Marine hydrothermal systems and the origin of lifechemical markers of prebiotic chemistry in hydrothermal systems: Origins Life Evol. Biosphere, 22, 109-134.

Ferris, J.P., Ertem, G., 1993, Montmorillonite catalysis of RNA oligomer formation in aqueous solution - a model for the prebiotic formation of RNA: Journal of the American Chemical Society, 115, 1227012275 .

Frei, R., Rosing, M.T., Waight, T.E., Krogstad, E.J., Storey, M., Ulfbeck, D.G., Albarède, F., 2002, Hydrothermal-metasomatic and tectonometamorphic processes in the Isua greenstone belt (West Greenland) - a multi-isotopic investigation of their effects on the Earth's oldest oceanic crustal sequence: Geochimica et Cosmochimica Acta, 66, 467-486.

Friend, C.R.L., Nutman, A.P., Bennett, V.C., 2002, Origin and significance of Archean quartzose rocks at Akilia, Greenland: Science, 298, p. 917.

Fry, I., 2000, The Emergence of Life on Earth - a historical and scientific overview: New Brunswick, New Jersey, Rutgers University Press, $327 \mathrm{p}$.

Fyfe, W.S., 1974, Geochemistry: Londres, Oxford University Press, 109 p.

Gilbert, W., 1986, The RNA world: Nature, 319, p. 618.

Guilbert, J.M., Park, C.F. Jr., 1986, The Geology of Ore Deposits: Nueva York, Freeman, $985 \mathrm{p}$

Haeckel, E., 1866, Enstehung der ersten Organismen, in Generelle Morphologie der Organismen 1: Berlín, George Reimer, 167-190.

Haldane, J.B.S., 1929, The origin of life: The Rationalist Annual, 148, 310
Halliday, A., 2000, Terrestrial accretion rates and the origin of the Moon: Earth and Planetary Science Letters, 176, 17-30.

Hazen, R.M., 2001, Life's rocky start: Scientific American, 284, 76-85.

Hiroi, T., Zolenski, M.E., Pieters, C.M., 2001, The Tagish Lake meteoritea possible sample from D-type asteroid: Science, 293, 2234-2236.

Holland, H.D., 1984, The Chemical Evolution of the Atmosphere and Oceans: Princeton, Nueva Jersey, Princeton University Press, 582 p.

Hoover, H.C., Hoover, L.H. (traductores), 1912 (1950), Georgius Agricola-De re metallica, traducido y comentado de la $1 .{ }^{a}$ edición en latín de 1556: Nueva York, Dover, xxxii + 638 p.

Hoyle, F., Wickramsinghe, N.C., 1977, Prebiotic molecules and interstellar grain clumps: Nature, 266, p. 241.

Huber, C. Wächtershäuser, G., 1997, Activated acetic acid by carbon fixation on $(\mathrm{Fe}, \mathrm{Ni}) \mathrm{S}$ under primordial conditions: Science, 276, 245-247.

Huber, C., Wächtershäuser, G., 1998, Peptides by activation of aminoacids with $\mathrm{CO}$ on $(\mathrm{Ni}, \mathrm{Fe}) \mathrm{S}$ surfaces - implications for the origin of life: Science, 281, 670-672.

Imai, E., Honda, H., Hatori, K., Brack, A., Matsuno, K., 1999, Elongation of oligopeptides in a simulated submarine hydrothermal system: Science, 283, 831-833.

James, H.L., 1954, Sedimentary facies of iron formation: Economic Geology, 49, 235-293.

Jia, Y., Kerrich, R., 2002, Secular decrease in atmosphere $\delta^{15} \mathrm{~N}-$ atmosphere origin and crustal cycling: Denver, Geological Society of America, Annual Meeting Abstracts with Programs, http:// gsa.confex.com/gsa/2002AM/finalprogram/abstract_40668.htm

Joyce, G.F., 2002, The antiquity of RNA-based evolution: Nature, 418, 214-221.

Kashefi, K., Lovley, D.R., 2003, Extending the upper temperature limit for life: Science, 301, p. 934.

Keller, E.F., 2002, Making Sense of Life-explaining biological development with models, metaphors and machines: Cambridge, Mass., Harvard University Press, 400 p.

Lazcano, A., 1995a, Aleksandr I. Oparin - the man and his theory, in Poglazov, B.F., Kurganov, B.I., Kritsky, M.S., Gladilin, K.L. (eds.), Frontiers in Physicochemical Biology and Biochemical Evolution: Moscú, Bakh Institute of Biochemistry and ANKO, 49-56.

Lazcano, A., 1995b, Alexander I. Oparin - apuntes para una biografía intelectual, in Morán, F., Peretó, J., Moreno, Á. (eds.), Orígenes de la vida - en el centenario de Aleksandr Ivanovich Oparin: Madrid, Editorial Complutense, $326 \mathrm{p}$.

Luther, A., Brandsch, R., von Kiedrowski, G., 1998, Surface-promoted replication and exponential amplification of DNA analogues: Nature, 396, 245-248.

Martin, W., Russell, M.J., 2003, On the origin of cells - an hypothesis for the evolutionary transitions from abiotic geochemistry to chemoautotrophic prokaryotes, and from prokaryotes to nucleated cells: Philosophical Transactions of the Royal Society of London, $358,59-85$.

McKay, D.S., Gibson, E.K., Thomas-Keprta, K.L., Vali, H., Romanek, C.S., Clemett, S.J., Chillier, X.D.F., Maechling, C.R., Zare, R.N., 1996, Search for past life on Mars - possible relic biogenic activity in martian meteorite ALH84001: Science, 273, 924-930.

Miller, A.R., 1964, High salinity in sea water: Nature, 203, 590-594.

Miller, S.L., 1953, A production of amino acids under possible primitive Earth conditions: Science, 117, 528-529.

Miller, S.L., 1998, The endogenous synthesis of organic compounds, in Brack, A. (ed.), The Molecular Origins of Life: Cambridge University Press, $417 \mathrm{p}$.

Miller, S.L., Bada, J.L., 1988, Submarine hot springs and the origin of life: Nature, 334, 609-611.

Miller, S.L., Urey, H.C., 1959, Organic compound synthesis on the primitive Earth: Science, 130, 245-251.

Miller, S.L., Schopf, J.W., Lazcano, A., 1997, Oparin's “Origin of life"sixty years later: Journal of Molecular Evolution, 44, 351-353.

Mojzsis, S.J., Arrhenius, G., 1998, Phosphate and carbon on Marsexobiological implications and sample return considerations: Journal of Geophysical Research, 103, 28495-28511. 
Mojzsis, S.J., Harrison, T.M., 2000, Vestiges of a beginning-clues to the emergent biosphere recorded in the oldest known sedimentary rocks: GSA Today, 10(4), 1-6.

Mojzsis, S.J., Harrison, T.M., 2002, Origin and significance of Archean quartzose rocks at Akilia, Greenland: Science, 298, p. 917.

Mojzsis, S.J., Arrhenius, G., McKeegan, K.D., Harrison, T.M., Nutman, A.P., Friend, C.R.L., 1996, Evidence for life on Earth before 3,800 million years ago: Nature, 384, 55-59.

Mojzsis, S.J., Harrison, T.M., Pidgeon, R.T., 2001, Oxygen isotope evidence from ancient zircons for liquid water at the Earth's surface 4,300 Myr ago: Nature, 409, 178-180.

Monnard, P.A., Apel, C.L., Kanavarioti, A., Deamer, D.W., 2002, Influence of ionic inorganic solutes on self-assembly and polymerization processes related to early forms of life-implications for a prebiotic aqueous medium: Astrobiology, 2, 139-152.

Nickerson, K.W., 1984, A hypothesis on the role of pressure in the origin of life: Theoretical Biology, 110(3), 487-497.

Nisbet, E.G., 1986, RNA and hot water springs: Nature, 332, p. 206.

Nutman, A.P., McGregor, V.R., Friend, C.R.L., Bennett, V.C., Kinny, P.D., 1996, The Itsaq Gneiss Complex of southern West Greenland-the world's most extensive record of early crustal evolution (3900-3600 Ma): Precambrian Research, 78, 1-39.

Nutman, A.P., Mojzsis, S.J., Friend, C.R.L., 1997, Recognition of $>3850$ Ma water-lain sediments and their significance for the early Archaean Earth: Geochimica et Cosmochimica Acta, 61, 24752484

Oftedahl, C., 1958, A theory of exhalative-sedimentary ores: Geologiska Föreningens i Stockholm Förhandlingar. 80, 1-19.

Ohmoto, H., Yamagushi, K.E., Watanabe, Y., Naraoka, H., Kakegawa, T., Lasaga, A.C., 2001, Geochemical evidence for oxygenated Archean oceans: Geological Society of America, Earth System Processesglobal meeting: http://gsa.confex.com/gsa/2001ESP/finalprogram/ abstract_7459.htm.

Oparin, A.I., 1924, El origen de la vida en la Tierra: Moscú, Pabochii, $1^{\text {a }}$ ed., (en ruso), número de páginas.

Oparin, A.I., 1924, Proiskhozhdenie zhizny [El origen de la vida]: Moscú, Izd. Moskoviskiy Rabochiy. Publicado en inglés, traducido por Ann Synge, como apéndice en Bernal, J.D., 1967, The origin of life: Londres, Weidenfeld and Nicolson, p. 199-234

Oparin, A.I., 1938, The origin of life on the Earth: Londres, Macmillan, $2^{\mathrm{a}}$ ed., $270 \mathrm{p}$.

Oparin, A.I., 1957, The origin of life on the Earth: Edinburgh, Oliver and Boyd, $3^{\mathrm{a}}$ ed., $495 \mathrm{p}$

Oparin, A.I., 2002, El origen de la vida: México, D.F., Editores Mexicanos Unidos, traducción al español de la $3^{\mathrm{a}}$ edición, 1957, $112 \mathrm{p}$

Palin, M., 2002, The origin of a most contentious rock: Science, 298, 961-962

Peltzer, E.T., Bada, J.L., Schlesinger, G., Miller, S.L., 1984, The chemical conditions on the parent body of the Murchison meteorite-some conclusions based on amino acids: Advances in Space Research, 4, 69-74.

Rebek, J. Jr., 1994, Synthetic self-replicating molecules: Scientific American, 271, 48-55.

Rees, D.C., Howard, J.B., 2003, The interface between biological and inorganic worlds - iron-sulfur metalloclusters: Science, 300, 929_ 931.

Russell, M.J., Hall, A.J., 1997, The emergence of life from iron monosulphide bubbles at a submarine hydrothermal redox and $\mathrm{pH}$ front: Journal of the Geological Society (Londres), 154, 377-402.

Russell, M.J., Hall, A.J., 2002, From geochemistry to biochemistrychemiosmotic coupling and transition element clusters in the onset of life and photosynthesis: The Geochemical News, 113, 6-12.

Russell, M.J., Hall, A.J., Cairns-Smith, A.G., Braterman, P.S., 1988, Submarine hot springs and the origin of life: Nature, 336, p. 117.

Russell, M.J., Hall, A.J., Rahman, L., Turner, D., 2001, The origin of life at a submarine alkaline seepage: Universidad de Glasgow, http:// www.gla.ac.uk/Project/originoflife/html/2001/abstract.htm.

Ryder, G., 1992, Chronology of early bombardment in the inner solar system (resumen): Geological Society of America Abstracts with Programs, 21, A299.
Sagan, C., Chyba, C., 1997, The early faint sun paradox - organic shielding of ultraviolet-labile greenhouse gases: Science, 276, 1217-1221.

Sánchez-Rubio, G., Rubinovich-Kogan, R., Lozano-Santa Cruz, R., Medina-Malagón, S., Flores-Gutiérrez, D., 2001, Las meteoritas de México: México, D.F., Universidad Nacional Autónoma de México, Instituto de Geología, Instituto de Geofísica e Instituto de Astronomía, $85 \mathrm{p}$

Schidlowski, M., 1988, A 3, 800 million-year-old record of life form carbon in sedimentary rocks: Nature, 333, 313-318.

Schidlowski, M., Appel, P.W.U., Eichmann, R., Junge, C.E., 1979, Carbon isotope geochemistry of the $3.7 \times 10^{9} \mathrm{yr}$ old Isua sediments, West Greenland - implications for the Archean carbon and oxygen cycles: Geochimica et Cosmochimica Acta, 43, 189-199.

Schilling, G., 2001, New model shows sun was a hot young star: Science, 293, 2188-2189.

Simmons, I., 2003, Not as we know it: http://www.nthposition.com/ people_russell.html.

Speiss, F.N., Macdonald, K.C., Atwater, T., Ballard, R., Carranza, A., Córdoba, D., Cox, C., Díaz-García, V.M., Francheteau, J., Guerrero, J., Hawkins, J., Haymon, R., Hessler, R., Juteau, T., MacDougall, J.D., Miller, S., Normark, W., Orcutt, J., Rangin, C., 1980, East Pacific Rise - hot springs and geophysical experiments on the East Pacific Rise: Science, 207, 1421-1433.

Strick, J., 2000, Sparks of Life-Darwinism and the Victorian debates on spontaneous generation: Cambridge, Mass., Harvard University Press, $304 \mathrm{p}$.

Taylor, S.R., 1992, Solar System Evolution-a new perspective: Cambridge, Cambridge University Press, 289 p.

Turekian, K.K., 1972, Chemistry of the Earth: Nueva York, Holt, Rinehart y Winston, $131 \mathrm{p}$.

van Hise, C.R., Leith, C.K., 1911, The geology of the Lake Superior iron region: U.S. Geological Survey Monograph, 52, 641 p.

van Zuilen, M.A., Lepland, A., Arrhenius, G., 2002, Reassessing the evidence for the earliest traces of life: Nature, 418, 627-630.

Vega, F., 1970, Científicos Griegos: Madrid, Aguilar, tomo 1, 998 p.

Wächtershäuser, G., 1988a, Before enzymes and templates - theory of surface metabolism: Microbiology Review, 52, 452-484.

Wächtershäuser, G., 1988b, Pyrite formation, the first energy source for life_a hypothesis: Systematic Applied Microbiology, 10, 207-210.

Weiss, R.F., Lonsdale, P., Lupton, J.E., Bainbridge, A.E., Craig, H., 1977, Hydrothermal plumes in the Galapagos Rift: Nature, 267(5612), 600-603.

Whitby, J., Burguess, R., Turner, G., Gilmour, J., Bridges, J., 2000, Extinct ${ }^{129} \mathrm{I}$ in halite from a primitive meteorite-evidence for evaporite formation in the early solar system: Science, 288, 1819-1821.

White, D.E., 1955, Thermal springs and epithermal ore deposits, in Bateman, A. M. (ed.), Economic Geology 50th anniversary volume 1905-1955: EUA, Urbana, The Economic Geology Publishing Company, part 1, 99-154.

White, D.E., 1974, Diverse origins of hydrothermal ore fluids: Economic Geology, 69, 954-973.

Wilde, A.S., Valley, J.W., Peck, W.H., Graham, C.M., 2001, Evidence from detrital zircons for the existence of continental crust and oceans on the Earth 4.4 Gyr ago: Nature, 409, 175-177.

Wöhler, F., 1828, On the artificial production of urea: Annalen der Physik und Chemie, 88: http://dbhs.wvusd.k12.ca.us/Chem-History/ Wohler-article.html.

Zolensky, M.E., Bodnar, R.J., Gibson, E.K. Jr., Nyquist, L.E., Reese, Y., Shih, C., Wiesmann, H., 1999, Asteroidal water within fluid inclusion-bearing halite in an H5 chondrite: Science, 285, 13771379 .

Manuscrito recibido: Junio 13, 2003

Manuscrito corregido recibido: Noviembre 13, 2003

Manuscrito aceptado: Noviembre 13, 2003 